Portland State University

PDXScholar

\title{
Vegetation, Environmental Characteristics, and their Relationships: Variation within the Annually Flooded Riparian Zones of the John Day River Basin, Oregon
}

Samuel J. Hartsfield

Portland State University

Follow this and additional works at: https://pdxscholar.library.pdx.edu/open_access_etds

Part of the Natural Resources and Conservation Commons, and the Natural Resources Management and Policy Commons

Let us know how access to this document benefits you.

\section{Recommended Citation}

Hartsfield, Samuel J., "Vegetation, Environmental Characteristics, and their Relationships: Variation within the Annually Flooded Riparian Zones of the John Day River Basin, Oregon" (2009). Dissertations and Theses. Paper 1718.

https://doi.org/10.15760/etd.1717

This Thesis is brought to you for free and open access. It has been accepted for inclusion in Dissertations and Theses by an authorized administrator of PDXScholar. Please contact us if we can make this document more accessible: pdxscholar@pdx.edu. 


\section{THESIS APPROVAL}

The abstract and thesis of Samuel J. Hartsfield for the Master of Science in Environmental Sciences and Resources were presented February 13, 2009, and accepted by the thesis committee and the department.

COMMITTEE APPROVALS:

Joseph Maser, Chair

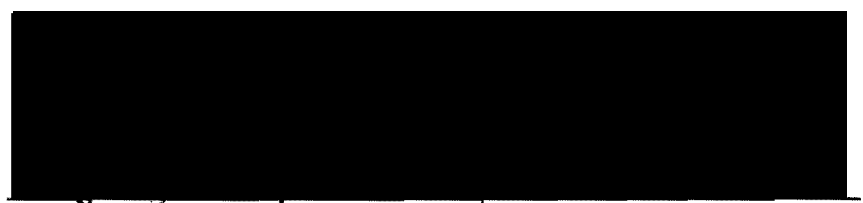

J. Ałan Yeakleyl
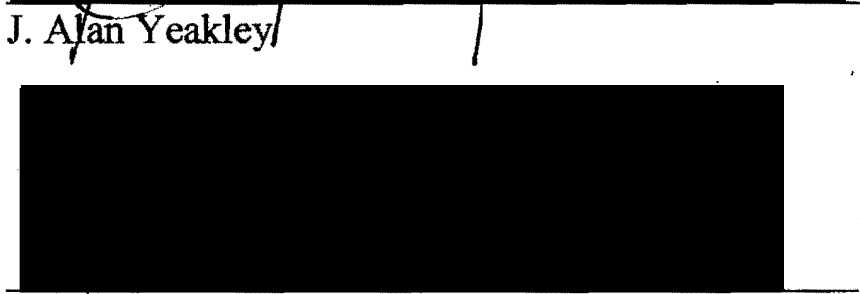

Scott Burns

DEPARTMENT APPROVAL:

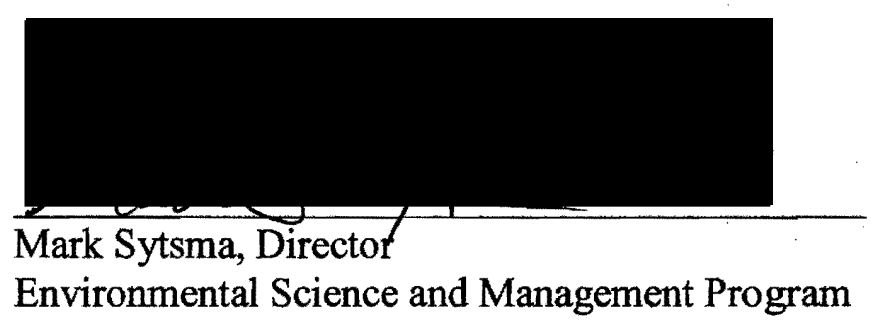




\begin{abstract}
An abstract of the thesis of Samuel J. Hartsfield for the Master of Science in Environmental Sciences and Resources presented February 13, 2009.
\end{abstract}

Title: Vegetation, Environmental Characteristics, and their Relationships: Variation within the Annually Flooded Riparian Zones of the John Day River Basin, Oregon

I hypothesized that vegetation and physical environmental characteristics would differ between the upper and lower extents of the annually flooded riparian zone on the John Day River, and that relationships between species and environmental variables would display differences between these two zones. Vegetation, environmental variables, and relationships between them were assessed for the entire annually flooded riparian zone, and for the proposed upper and lower zones. Data were collected from 60 one-square-meter quadrats: 30 in each the upper and lower zones. Sites were randomly selected and located so that flood duration was roughly equal at all sites within each zone.

34 plant species were encountered: 25 in the upper zone, 27 in the lower zone. Wetland obligate and facultative wetland species groups and eight individual species accounted for statistically different percentages of quadrat cover between zones. ANOSIM analysis identified two statistically distinct vegetation communities between the two zones. 
Soil texture averaged $75.85 \%$ sand and $20.81 \%$ fines. Sand ranged between $36.69 \%$ and $95.55 \%$. Fines ranged between $2.54 \%$ and $58.84 \%$. A horizon depths and fine soil particle concentrations were greater in the upper zone. Coarser soils with more sand and gravel dominated the lower zone. All environmental variables studied, except $\mathrm{pH}$, were highly variable throughout the study area. ANOSIM analysis results suggest that the upper and lower zones have distinct, statistically different physical environments from each other.

Regression analyses relating species quadrat cover to physical environmental variables were performed for the total, upper, and lower riparian zones. Numerous differences were identified between the upper and lower riparian zones that the riparian scale analyses did not represent accurately. There were ten instances in which the zone scale analyses identified a relationship in either the upper or lower zone, while the corresponding riparian scale analysis failed to identify any relationship.

The results of this study indicate that vegetation and the physical environment are statistically different between the upper and lower zones on this river, and that relationships between a given plant species and environmental variable can vary between zones. Future research and management efforts should consider and address the potential for such between-zone variation. 
VEGETATION, ENVIRONMENTAL CHARACTERISTICS, AND THEIR

RELATIONSHIPS: VARIATION WITHIN THE ANNUALLY FLOODED

RIPARIAN ZONES OF THE JOHN DAY RIVER BASIN, OREGON

by

SAMUEL J. HARTSFIELD

A thesis submitted in partial fulfillment of the

requirements for the degree of

\author{
MASTER OF SCIENCE \\ in \\ ENVIRONMENTAL SCIENCES AND RESOURCES
}

Portland State University

2009 


\section{ACKNOWLEDGEMENTS}

My sincere appreciation goes to the following people, without whom my completing this task would have been impossible. Thanks to my committee, Dr. Joe Maser, Dr. Scott Burns, and Dr. Alan Yeakley, who provided support, direction, input, patience and enthusiasm throughout the prolonged experience of a student completing a Master's degree while working full time and having children. I appreciate that through the years each has continued to provide material, academic, and moral support. Thanks to Josh Caplan, whose statistics tutoring has meant a great deal, but not as much as his friendship. Thanks to Kate Norton and Dr. Yangdong Pan for their insight and generous help in guiding me through my statistical analyses. Thanks to Dan Tippy of the Bureau of Land Management for allowing me to conduct my field work on land for which he had administrative responsibility. Thanks to my mom, Donna Penick, for the late night adventures in document formatting. Thanks to my dad, Joe Hartsfield, for all the support and for being proud of me.

Most of all, thanks to my wife Melissa, my daughter Audrey Nova, and my son Ian Gabriel Raymond, for tolerating my absence every Saturday for the last year and the stress that goes along with this kind of endeavor; for their bottomless well of love; and for reminding me every day with a hug and a kiss why I am here. 


\section{TABLE OF CONTENTS}

ACKNOWLEDGEMENTS............................................................................................... $\mathrm{i}$

LIST OF TABLES ........................................................................................................................... iv

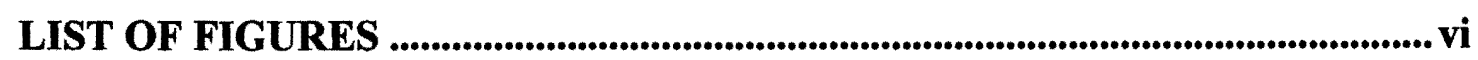

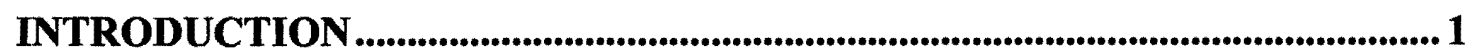

OBJECTIVES.................................................................................................................................... 4

BACKGROUND......................................................................................................................................5 5

Floodplains And Riparian Ecosystems …………………..................................

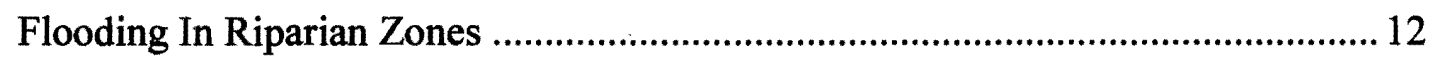

Floodplain Geomorphology ............................................................................. 15

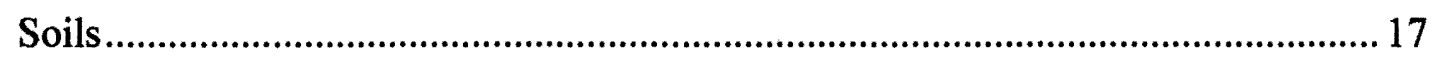

Need For Further Study Of Fine-Scale Floodplain Physical And Riparian

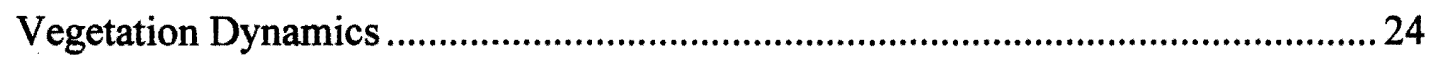

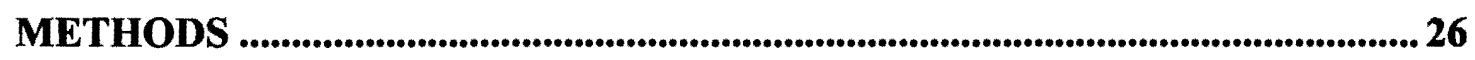

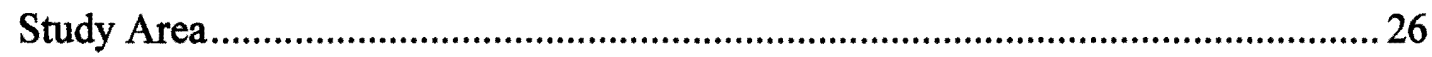

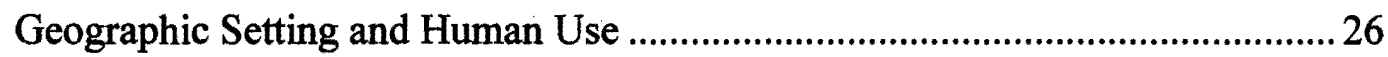

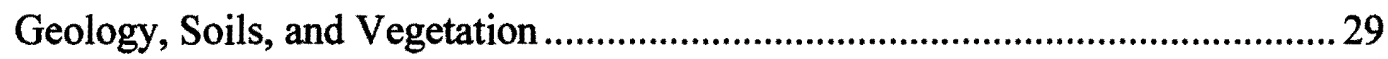

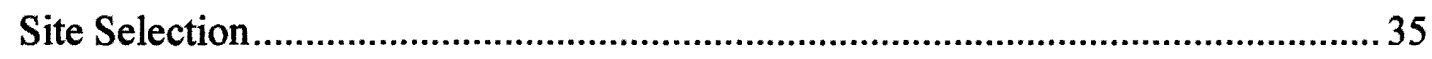

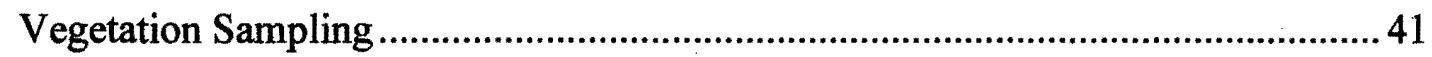

Physical Environmental Factors: Field Sampling ..................................................... 42

Physical Environmental Factors: Laboratory Procedures ......................................... 43

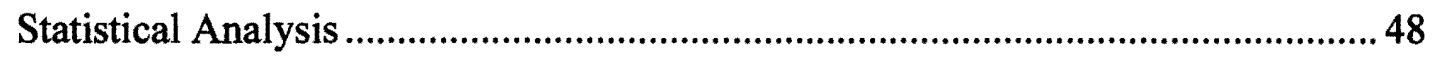

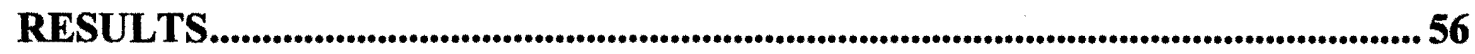

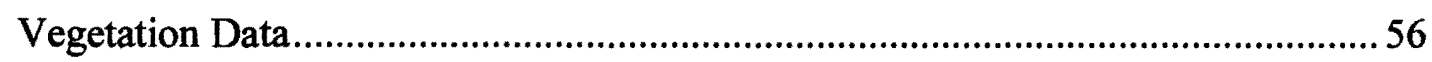

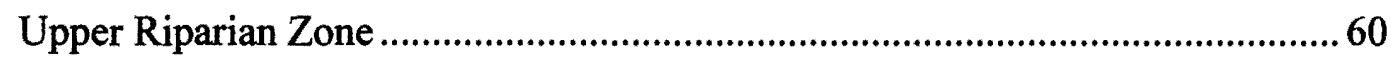

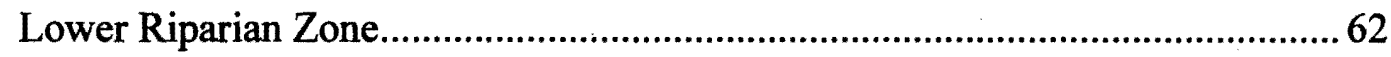

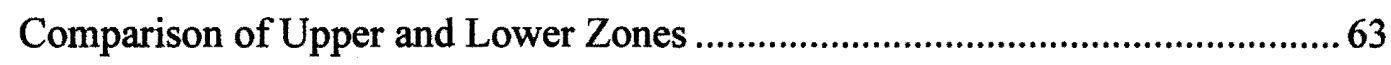

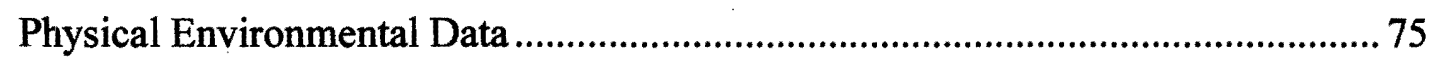

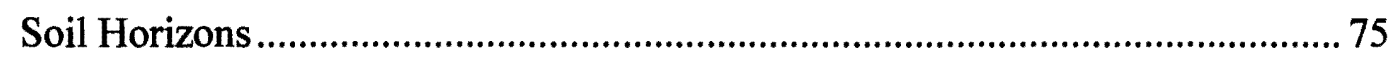


Depth of A horizon/ Depth to C horizon ................................................................. 76

Average 3 meter slope gradient........................................................................... 76

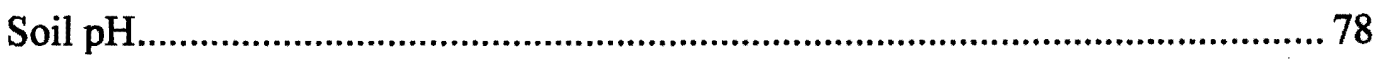

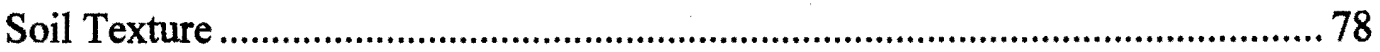

Multivariate Analyses ........................................................................................ 83

Single Linear Regressions-Plant-Environmental Variable Relationships .............. 88

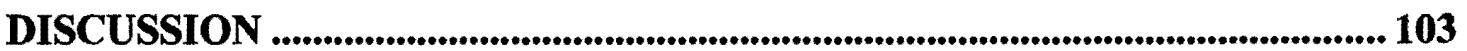

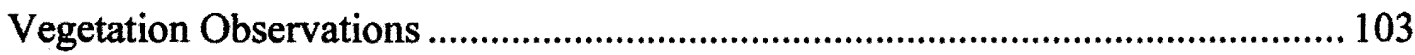

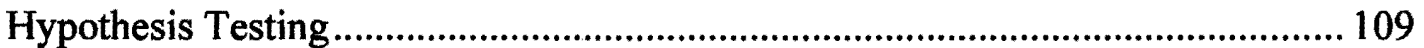

$\mathrm{H}_{\mathrm{O} 1}$ : There is no difference in herbaceous and woody sapling plant composition between the upper and lower floodplain. ........................................................... 109

$\mathrm{H}_{\mathrm{O} 2}$ : There is no difference in depth of the A horizon, local surface slope gradient, soil $\mathrm{pH}$, and soil texture, between the upper and lower floodplain..... 112

$\mathrm{H}_{\mathrm{O} 3}$ : There is no difference in relationships between herbaceous and woody sapling plant composition and soil texture, soil $\mathrm{pH}$, local surface slope gradient, and depth to $\mathrm{C}$ horizon, between the upper and lower floodplain........................ 117

Research and Management Implications.................................................................. 127

SUMMARY AND CONCLUSION.................................................................................. 134

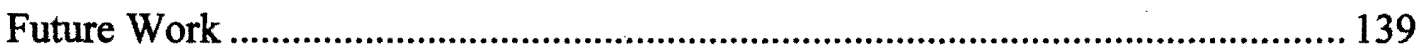

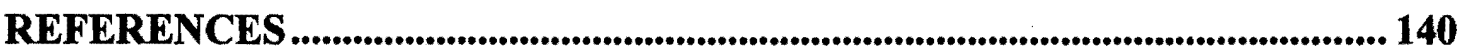

APPENDIX A: SINGLE LINEAR REGRESSION ANALYSIS DETAILED

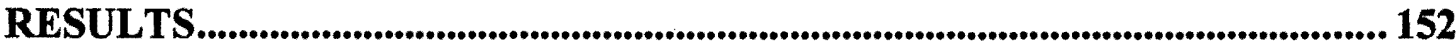

APPENDIX B: RESIDUAL VS. THEORETICAL QUANTILE PLOTS FOR

RELATIONSHIPS IDENTIFIED IN ONLY ONE ZONE ........................................ 163 


\section{LIST OF TABLES}

Table 1. Location of Upper and Lower Sample Site Numbers ....................................38

Table 2. Schedule and Depth of Withdrawals for Pipette Method................................. 47

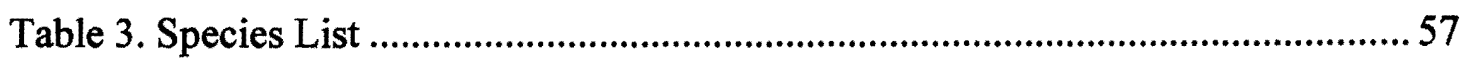

Table 4. Percent of Total Vegetation Cover by Species .................................................5 58

Table 5. Dominant Species Percent of Quadrat Cover - Basic Descriptive Statistics.. 61

Table 6. Descriptive Statistics for Percent Quadrat Cover by Wetland Indicator Status

Table 7. Dominant Species Percent of Total Vegetation Cover - by Zone .................. 64

Table 8. Vegetation Cover Ranks - Dominant Species by Zone ................................... 65

Table 9. Dominant Species Percent Quadrat Cover, Mann-Whitney Test Results ...... 68

Table 10. Summary of Mean Quadrat and Percent of Total Cover by Species with Significantly different Mean Quadrat Cover (Reject Mann-Whitney $\mathrm{H}_{\mathrm{o}}$ ) ....................6 68

Table 11. T-Test Results for Percent of Quadrat Cover by Wetland Indicator Status . 69

Table 12. Principle Components Analysis for Total Riparian Dominant Species ....... 71

Table 13. Principle Components Analysis for Upper Riparian Dominant Species ..... 72

Table 14. Principle Components Analysis for Lower Riparian Dominant Species ..... 73

Table 15. Summary of Environmental Data............................................................. 77

Table 16. Mann-Whitney Test Results for Environmental Variables ........................... 77

Table 17. Summary of Sand Fraction Analysis............................................................. 80

Table 18. Principal Components Analysis for Total Riparian Zone Environmental

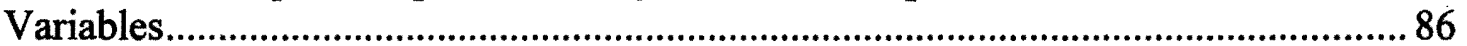

Table 19. Principal Components Analysis for Upper Riparian Zone Environmental Variables.

Table 20. Principal Components Analysis for Lower Riparian Zone Environmental Variables

Table 21. Summary of Dominant Species \% Quadrat Cover vs. Environmental Variable Single Linear Regressions, Part 1 of 4

Table 22. Summary of Dominant Species \% Quadrat Cover vs Environmental Variable Single Linear Regressions, Part 2 of 4 95

Table 23. Summary of Dominant Species \% Quadrat Cover vs Environmental Variable Single Linear Regressions, Part 3 of 4 
Table 24. Summary of Dominant Species \% Quadrat Cover vs Environmental Variable Single Linear Regressions, Part 4 of 4

Table 25. Summary of Wetland Indicator Status Group \% Quadrat Cover vs.

Environmental Variable Single Linear Regressions .................................................... 98

Table 26. Relationships Identified Only in Upper Riparian Zone ............................ 100

Table 27. Relationships Identified Only in Lower Riparian Zone ............................. 100

Table 28. Wetland Indicator Status Group Relationships Identified in Only One Zone

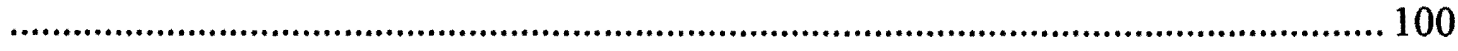

Table 29. Relationships with influential points identified by Cook's D...................... 100 Table 30. Summary of Verified Significant Relationships Identified in Only One Zone 


\section{LIST OF FIGURES}

Figure 1. Location of John Day River Basin............................................................ 27

Figure 2. John Day River Basin and Study Area Overview........................................... 27

Figure 3. Typical Landscape and Vegetation of John Day River Basin, Near Service

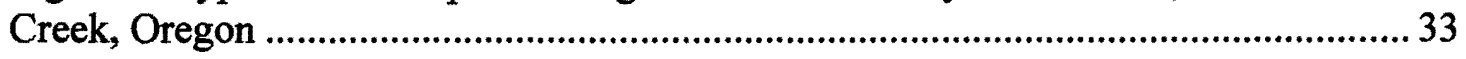

Figure 4. Example of John Day River Riparian Zone, Near Spray, Oregon................. 34

Figure 5. Study Site Locations (1 of 2) ......................................................................... 37

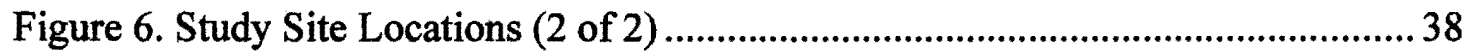

Figure 7. Example of Site Locations .......................................................................... 40

Figure 8. Percent of Total Cover by Wetland Indicator Status ..................................... 59

Figure 9. Dominant Species Cover by Zone ...............................................................6 66

Figure 10. Multidimensional Scaling (MDS) Plot for Dominant Species ................... 70

Figure 11. Multidimensional Scaling (MDS) Plot for Environmental Variables ........ 85 


\section{INTRODUCTION}

During the past 150 years, a variety of human activities have altered or degraded riparian ecosystems in the western United States (Malanson 1993, Castelli et al. 2000, Patten 1998). Land managers, environmental groups, and many citizens now recognize the important role that riparian zones play in protecting water quality, mitigating flood impacts, providing wildlife habitat, and increasing regional biodiversity (Lowrance and Sheridan 2005, Tockner and Ward 1999, Wissmar 2004, Gomi et al. 2006). Efforts are currently underway to restore vegetation, landscape features, and ecological functions of floodplains on streams throughout the world. Efforts range from reintroducing natural flood regimes and removing unnatural exogenous disturbances, such as livestock grazing, to large-scale reconstruction of floodplain geomorphic features and extensive planting of riparian wetland vegetation (Martin and Chambers 2002, Fullerton et al. 2006, Katz et al. 2007, Shah et al. 2007, Vercoutere et al. 2007). Scientists and land managers must understand relationships between physical environmental characteristics and vegetation of floodplains at numerous scales to maximize success of restoring and conserving riparian ecosystems.

Scientific studies and floodplain management plans often treat a floodplain as a single ecological unit extending from the edge of a stream at base flow to the extent of flooding at some regular time interval. This basic assumption has not been scientifically tested and may or may not be appropriate. Research has established that patterns of vegetation and physical environmental characteristics exist in floodplains, based on such factors as inundation duration, sedimentation dynamics, and flood 
scouring (Harris 1987, Stromberg et al. 1997, Castelli et al. 2000, Dwire et al. 2004, Wintle and Kirkpatrick 2007, Boudell and Stromberg 2008). Environmental variables such as soil properties and surface slope gradient exhibit a high degree of spatial variability in floodplain landscapes (Poff et al. 1997, Florsheim and Mount 2002, Gallardo 2003, Wintle and Kirkpatrick 2007). Numerous studies have found significant relationships between riparian vegetation and various environmental variables on a floodplain-wide scale, and have identified patterns based on lateral environmental gradients perpendicular to stream channels (Dwire et al. 2004, Salinas and Casas 2007, Boudell and Stromberg 2008). However, little to no research has examined fine-scale dynamics between riparian vegetation and floodplain environmental features within areas that are subjected to similar inundation regimes, or how they may differ between floodplain zones parallel to the channel, but subjected to different inundation regimes. Bayley (1995) and Smith et al. (1998) point out the needs for special studies to address specific fine scale elements of the hydrological cycle within floodplains.

In this study, I measured soil texture, soil $\mathrm{pH}$, local surface slope gradient, and depth to $\mathrm{C}$ horizon, and examined relationships between these environmental parameters and herbaceous and woody sapling vegetation. I conducted the study in the floodplain of a large undammed river in two zones subjected to a 1-year flood frequency, but with different inundation durations and compared vegetation patterns, environmental parameters, and the relationships between vegetation and environmental parameters between the two distinct zones. This study is a step toward 
more detailed understanding of floodplain and riparian ecosystems. Results from the study may either confirm that the common floodplain-wide approach to studying and managing these ecosystems is appropriate, or give scientists and land managers useful insight to better utilize resources in future research, restoration, and conservation efforts. 


\section{OBJECTIVES}

The first objective of this study was to determine if two zones ("upper" and "lower") with different annual flood durations, within a single floodplain, have the same vegetation and environmental characteristics. The second objective was to examine relationships between vegetation and environmental variables within each of these zones, and determine whether any relationships are common to both zones. Conducting the study in arid eastern Oregon, where climate pressures on wetland plants are great, ensured that fine scale differences in environmental parameters would have magnified effects on the vegetation. The null hypotheses tested were:

Ho1: There is no difference in herbaceous and woody sapling plant composition between the upper and lower floodplain.

$\mathbf{H}_{\mathbf{0 2}}$ : There is no difference in depth of the A horizon, local surface slope gradient, soil $\mathrm{pH}$, and soil texture, between the upper and lower floodplain. $\mathbf{H}_{\mathbf{0 3}}$ : There is no difference in relationships between herbaceous and woody sapling plant composition and soil texture, soil $\mathrm{pH}$, local surface slope gradient, and depth to $\mathrm{C}$ horizon, between the upper and lower floodplain. 


\section{BACKGROUND}

\section{Floodplains And Riparian Ecosystems}

Riparian zones exist at the interface between terrestrial and aquatic ecosystems, and are characterized by their association with stream edges and by the annual cycle of disturbance that occurs when the stream floods (Karr and Schlosser 1978, Frissell et al. 1986, Gregory et al. 1991, Naiman and Decamps 1997, Mitsch and Gosselink 2000). In the western United States, riparian zones comprise less than 1 percent of total land area, but they provide a range of benefits to regional ecology and water quality that make them valuable landscape features (Benson 1996, Naiman and Decamps 1997). They may be classified as wetlands according to criteria set forth by the US Fish and Wildlife Service (Cowardin et al 1979), the US Army Corps of Engineers Wetlands Delineation Manual (1987), and section 404 of the Clean Water Act. The criteria for wetland designation are:

1) Predominance of macrophytic vegetation that is adapted to anaerobic conditions

2) Soils that are classified as hydric or that possess characteristics associated with reducing soil conditions.

3) Permanent or periodic inundation or saturation to the soil surface during the growing season (US Army Corps of Engineers 1987).

Unlike some freshwater wetlands, riparian wetlands have a regular flux of energy, materials, and nutrients into and out of the system via their associated stream. 
This flux has three major effects. First, the disturbance creates a spatially and structurally heterogeneic ecosystem through a variety of mechanisms (Hunter et al 1987, Scott et all 1997, Patten 1998, Smith et al 1998, Mitsch and Gosselink 2000, Shafroth et al. 2002). Second, the stream regularly transports nutrients into the riparian zone while flushing toxins, salts, and excess leaf litter out of the system (Cummins 1974, Gregory et al. 1991, Mitsch and Gosselink 2000). Third, the stream provides soil moisture and recharges soil pore water through flooding. This hydrology influences vegetation composition, often creating an ecosystem that has more and different species than the surrounding landscape (Naiman and Decamps 1997, Patten 1998, Mitsch and Gosselink 2000, Crawford and Semlitsch 2007). Riparian zones mediate an exchange of important nutrients from the aquatic system into the terrestrial system by directly depositing nutrients from floodwater into the soil during flooding, through deposition of aquatic organism carcasses into the floodplain, and through terrestrial predation on aquatic organisms (Bayley 1995, Schade et al. 2005, Sanzone et al. 2003). The result of these factors is that riparian wetlands are very diverse and productive ecosystems (Baker and Barnes 1998, Dobkin et al 1998, Patten 1998, Tockner and Ward 1999, Mitsch and Gosselink 2000).

Riparian corridors are widely recognized as important features of many regional landscapes (Gregory et al. 1991, Naiman et al. 1993, Naiman and Decamps 1997). Floodplain physical characteristics and riparian vegetation perform a range of functions that benefit water quality in associated streams, as well as terrestrial and aquatic biota (Allan 1995, Mitsch and Gosselink 2000, Lowrance and Sheridan 2005, 
Cavalcanti and Lockaby 2006). Riparian trees provide shade that helps moderate and regulate stream temperatures (Cummins 1974, Gomi et al. 2006), and reduce direct sunlight reaching the stream, potentially influencing periphyton abundance (Kiffney et al. 2004). These trees also provide large woody debris that moderates stream flow velocities and influences channel morphology (Malanson and Butler 1990, Allan 1995, Bragg and Kershner 1999). Runoff from a watershed generally is slowed by riparian vegetation more effectively than by the upland vegetation in the surrounding landscape (Clary 1995, Mergen et al 2001, Lowrance and Sheridan 2005). Floodplains tend to have relatively moderate longitudinal slope gradients, as well as numerous depressions that serve to store or slow the flow of water and sediment from overland flow events (Patten 1998, Bridge 2003). Precipitation interception and evapotranspiration by riparian plants further reduce runoff rates. These vegetation and physical features result in smaller, delayed flood peaks in associated streams after rain events (Likens 1984, Wright et al. 1990, Smith et al. 1998). The vegetation root masses also stabilize the stream banks on which they grow, reducing erosion and sedimentation of the streambed (Manning 1979, Gary et al. 1983, Baker and Barnes 1998). Streams in largely agricultural watersheds benefit from riparian zones, which act as buffers between uplands and streams (Lowrance et al. 1984). In many of these watersheds, non-point source pollution is a problem that has been mitigated to varying degrees by restoring riparian zones and enhancing buffers (Lowrance et al. 1984, Kovacic et al 2000, Anbumozhi et al. 2005). 
Structural features of floodplains and riparian vegetation provide cover and refuge, migration corridors, breeding locations, and important food sources for terrestrial and aquatic fauna. Riparian vegetation tends to be dense and diverse, providing cover in proximity to water resources. This makes floodplain wetlands attractive landscape features for a variety of terrestrial fauna. Some land animals live in the surrounding landscape, but use the riparian zones on a daily basis for water and feeding, or seasonally for specific life history requirements such as breeding (Knopf and Sedgwick 1992). Others are dependent on features that are unique to the riparian zone for their entire lives (Steel et al. 1999, Crawford and Semlitsch 2007). Because they provide extensive cover and access to ample water resources, riparian corridors provide valuable migration routes for many terrestrial animal species (Skagen et al. 2005, Pennington et al. 2008).

Many fish, amphibian, and macroinvertebrate species directly depend on flooded riparian vegetation and floodplain landscape features for breeding and as nursery locations (Gregory et al. 1991, Opperman and Merenlender 2004). By stabilizing stream banks and reducing erosion and the resulting sedimentation of the stream bed, riparian zones play an important role in preserving in-stream spawning locations for species such as salmon (Schiemer and Zalewski 1992, Davies and Nelson 1994). Large woody debris from riparian trees is critical for developing certain stream morphological features, such as riffles and pools that aquatic fauna depend on for feeding, migration, and breeding. This debris also provides hiding places for fish (Opperman and Merenlender 2004). Litter input from riparian plants provides a 
substrate for the microorganisms that are the base of many stream food webs (Cummins 1974, Melillo et al. 1982, Barcholer 1983). Floodplain inundation tightly controls the abundance of macroinvertebrates consumed by fish (Grosholz and Gallo 2006).

Riparian zones often have the highest biodiversity of any area within a given landscape (Naiman et al 1993, Patten 1998, Gallardo 2003). The dynamic nature of disturbance within a riparian zone creates a patchy mosaic of environmental conditions that result in a variety of life history strategies of resident plants and animals (Gregory et al. 1991, Hobbs and Huenekke 1992, Kalliola and Puhakka 1988. Naiman et al 1993). As previously discussed, upland wildlife uses riparian zones for access to water, for shade and shelter, and for forage, while aquatic animals may rest and spawn in flooded riparian zones (Cummins 1974, Gregory et al. 1991, Knopf and Sedgwick 1992, Davies and Nelson 1994). Breeding, nesting, and hunting success are tied to riparian structural diversity for a number of sensitive neotropical migrant birds (Knopf and Sedgwick 1992, Sanders and Edge 1998).

Intact, functional riparian zones and floodplains often provide substantial social and economic benefits to humans as well. Floodplains provide surface water storage, while riparian vegetation increases surface roughness, reducing the severity of flood events (Allan 1995, Patten 1998, Bridge 2003). This reduces the cost to municipalities and land managers for flood control measures and structures, as well as impacts to home- and landowners and their insurers. Governments, scientists, and 
citizens place value on biodiversity, which riparian corridors substantially enhance (Naiman et al 1993, Patten 1998).

Floodplain and riparian ecosystems provide tremendous value to animals for cover and spawning, and for protecting water quality on which aquatic organisms depend. Intact riparian zones that retain complex physical, hydrologic, and biotic features typical of undisturbed riparian areas protect fisheries and the economies that depend on them, and are important components in providing and preserving critical habitat for a variety of animals protected by the Endangered Species Act (Sanders and Edge 1998, Pusey and Arthington 2003).

Riparian zones are frequently used for recreation (Manning 1979, Green 1998). Activities common in these ecosystems include picnicking, bird watching, land-based camping, boating-oriented camping, hiking, and fishing. People, like most vertebrates, are attracted to the water for a variety of reasons, so whether riparian zones are destinations or simply areas passed through during trips to the water, they are used frequently in the course of recreation.

Riparian zones in arid landscapes assume an increased significance. The wetland plants that inhabit the flood zones of waterways contrast starkly with the upland vegetation surrounding them (Smith et al 1991, Patten 1998, Shafroth et al. 1998, Shafroth et al. 2002, Wissmar 2004). Differences are morphological,' physiological, reproductive, and structural (Smith et al 1991, Smith et al 1998, Mitsch and Gosselink 2000). For example, juniper (Juniperus spp.), which may grow as a large shrub or small tree, covers countless acres of land in the arid western United 
States. It has very low water demands, grows fairly sparsely, and may become a dominant plant in arid regions during times of drought, due to its ability to survive with very little rainfall (Mueller et al. 2005). Many riparian plants are wetland obligate or facultative wetland species that cannot survive on local rainfall, and require a supplemental supply of stream water (Patten 1998). Black cottonwood (Populus trichocarpa), which is common in many riparian zones throughout the Pacific Northwest, has high water demands, can grow in dense stands, and is one of the largest hardwood trees in the western United States. Soil moisture conditions required to grow cottonwood trees would kill off juniper, which is not adapted to survive hydric or reducing soil conditions. Conversely the high water demands of cottonwood prevent it from growing on the dry sites to which juniper is adapted (Scott et al. 1997).

Many of the physical adaptations to arid conditions that upland plants in dry regions possess (such as high lignin concentrations) make their leaves of lower nutritional value to aquatic organisms (Melillo et al. 1982, Webster and Benfield 1986). The shrubby form of desert and steppe plants also limits their contribution to large woody debris in streams. As opposed to more humid landscapes, where upland plants may contribute nutritious leaves and large woody debris, arid region streams depend almost exclusively on riparian zones for these inputs (Patten 1998).

Riparian wetlands provide such great value to humans, animals, streams, and landscape-level ecosystems that it is important to understand the processes that drive and sustain them at both coarse and fine scales. This understanding can give scientists 
and land managers useful insight to better use resources in research, restoration, management, and conservation efforts.

\section{Flooding In Riparian Zones}

Virtually all ecological processes, structural features, and vegetation characteristics in riparian zones are related to cycles of flooding by associated streams (Gregory et al. 1991, Bayley 1995, Richter and Richter 2000, Bendix and Hupp 2000). Flooding in many terrestrial ecosystems is uncommon and may be disruptive to normal functioning of the ecosystem. In riparian zones, flooding is considered an endogenous disturbance that is necessary for the ecosystem to function normally (Gregory et al. 1991, Schade et al. 2005, Boudell and Stromberg 2008). Effects of flooding on riparian zones vary depending on force, duration, timing, extent, and depth of flood events (Bayley 1995, Bendix and Hupp 2000, Mitsch and Gosselink 2000, Shafroth et al. 2002). According to the River Continuum Concept, flooding also exposes riparian zones to the effects of processes that occur upstream in the watershed (Vannote et al. 1980). For example, sediment from mass wasting events in upland landscapes may eventually be washed into a river and deposited in floodplains hundreds of miles downstream. This often creates floodplain soils that have parent material and physical and chemical properties that differ substantially from those of the adjacent upland soils, resulting in great variability of soil types over short distances (Vannote et al. 1980, Gregory et al. 1991, Bayley 1995, Gallardo 2003). 
Scouring effects of flood events directly influence riparian vegetation by mechanically damaging, killing, or removing existing vegetation. This alone creates patches of plant distribution within a floodplain (Gregory et al. 1991, Bendix 1999). Plants damaged, but not killed or removed by flood action may become unable to compete with other plants that survive the flooding or that the water deposits on adjacent sites (Bendix 1999). Riparian plant species possess various adaptations to withstand and survive mechanical damage and scouring from floods such as flexible stems, deep roots, and dense rhizomatous root systems (McBride and Strahan 1984, Bornette and Amoros 1996, Karrenberg et al. 2002). Different life stages of a single species may also be more or less susceptible to direct physical stresses of flooding, so flood force may have a strong influence over spatial distribution of plants in a floodplain (Stromberg et al. 1997, Rood et al. 1998, Bendix 1999). Numerous important wetland plant species, particularly in the family Salicaceae, are capable of vegetative reproduction. Floodwater forces often break off pieces of these plants, move them downstream, and ultimately deposit them in the floodplain where the segments produce roots and establish new clonal plants (Karrenberg et al. 2002). The scouring action of floods removes vegetation and accumulated leaf litter, exposing mineral soil, and producing new seedling establishment sites for many riparian species (Rood et al. 1998, Shafroth et al. 1998, Shafroth et al. 2002).

Flood duration directly influences plant productivity and species composition in riparian zones. Oxygen available to plants is depleted rapidly during inundation periods. Upland plant species generally have little tolerance for oxygen stress, so 
annual flooding maintains riparian vegetation that is largely comprised of wetland and facultative wetland species (Gregory et al. 1991, Mitsch and Gosselink 2000, Bagstad et al. 2005). Different wetland plant species have specific tolerances for oxygen stress, so flood duration also may influence wetland obligate species composition (Pezeshki et al. 1998, Bagstad et al. 2005, Lite et al. 2005). Studies of numerous riparian plant species (including Baccharis salicifolia [FAC], Betula occidentalis [FACW], Populus fremontii [FACW], and Salix gooddingii [OBL to FACW]) in arid land riparian zones found that seedlings subjected to only short duration floods died quickly due to lack of soil water, while those exposed to particularly long flood durations either died or displayed reduced growth and productivity (Smith et al. 1991, Rood et al. 1998, Shafroth et al. 1998, Smith et al. 1998). Longer periods of inundation can recharge soil moisture to greater degrees, increasing the availability of soil and groundwater to plants after flooding recedes (Dingman 2002).

Flood timing can influence riparian plants in a number of ways. Prolonged floods during the active growing season may kill xeric plant species not adapted to oxygen stress (Smith et al. 1998, Mitsch and Gosselink 2000). A common riparian plant reproductive strategy is to produce seeds that are timed with a particular stage (often toward the end) of the annual flood period (Auble et al. 1994). This adaptation ensures dispersal of seeds downstream and deposition upslope into the floodplain by rising and then receding water. Seeds deposited on a floodplain during a flood benefit from increased soil moisture during the germination and establishment process (Rood and Mahoney 1995, Shafroth et al. 1998). 
The horizontal extent of flooding often creates zonation of plant and geomorphic features of riparian zones. Locations closest to the active stream channel are affected by flooding more frequently and for longer durations than those further from the channel. This generally results in greater soil and groundwater recharge and more soil saturation closer to the stream (Bayley 1995, Dingman 2002). Stream flow velocities and associated scouring and abrading properties tend to be greatest near a stream as well, with decreasing impacts further from the stream. A combination of factors such as sedimentation dynamics, mechanical impacts to plants, and duration of flooding results in demonstrable zonation of vegetation moving away from the stream (Robertson et al. 1978, Harris 1987, Stromberg et al. 1997, Bendix 1999). The location of seed deposition within a floodplain is largely a function of the geographic extent of flooding, and the success of seedlings for different species is often tied to varying moisture regimes that show distinct lateral patterns in a floodplain (Shafroth et al. 1998).

\section{Floodplain Geomorphology}

Many feedbacks exist between floodplain vegetation, geomorphology and flooding, with each aspect affecting the others. Plant roots can physically stabilize sediment and they secrete organic materials that bind soil particles together, both of which help reduce rates of erosion and stabilize stream banks (Angers and Caron 1998, Simon and Collison 2002, Francis 2006). Plants growing in the floodplain increase surface roughness, thus slowing water velocities during flooding. This results 
in decreased direct erosion, as well as increased sedimentation rates as the flow velocity slows (Ambasht et al. 1984, Walling and He 1997). Some riparian species, such as Carex spp. efficiently trap sediment between their aboveground tissues (Helmers et al. 2005, Lowrance and Sheridan 2005). The result of this combination of features is vertical accretion that can increase the height of floodplains. Vertical accretion may ultimately produce a site that is rarely flooded and has a greater depth to groundwater, effectively changing the hydrology, depth to groundwater, and finally the vegetation at that site (Hughes 1997). Conversely, the scouring effect of floods can reduce the depth to the water table and create new localized depressions that may hold water for some time after flood recession. Studies have shown that this can create new marshes in arid floodplains at sites that are not flooded on an annual basis (Stromberg et al. 1997). Feedbacks between flooding, existing geomorphology, resulting sedimentation patterns, and plants create a spatially heterogeneous physical landscape in floodplains (Gregory et al 1991, Stromberg et al. 1997).

Flood dynamics and the interaction between floodwater sediments, plants, and floodplain surface and channel features influence floodplain evolution (Walling and He 1997). Sedimentation rates follow broad trends across horizontal cross sections of a floodplain, with the highest rates closer to edge of the stream at baseflow (Walling and $\mathrm{He}$ 1997). Sediment particle size is also generally predictable across a floodplain. Coarser sediment with higher settling velocities is generally deposited close to the channel, while finer sediments are deposited further from the channel (Marriott 1992, -Asselman and Middelkoop 1995, Walling and He 1997). 
While broad trends of sediment deposition exist in a floodplain, a number of physical and hydraulic factors combine to create spatially heterogeneous floodplain surface. Hummocks, depressions, boulders, cobbles, and other microtopographical features decrease flow velocities and create impoundments, further promoting deposition from flood water. Finer sediments will fall out of a water column as water flow velocity decreases with further distance from the stream channel (Asselman and Middelkoop 1995). The amount of sediment deposited per unit area is proportional to the total mass of sediment in the overlying water column, which is proportional to water depth (Marriot 1992). Therefore, a variety of floodplain features, such as width, surface slope gradient, and microtopographical features that influence flood depth, affect sedimentation and result in significant spatial variability of particle size distribution within a floodplain (He and Walling 1997).

\section{Soils}

Soils are natural bodies composed of organic and mineral materials, air, water, and living organisms, each of which influences the other (Gerrard 2000). These features and the processes associated with them are important factors in the structure and function of riparian ecosystems (Mitsch and Gosselink 2000, Lewis et al. 2003). Soil forming factors include climate, biological processes, topography, parent material, and time (Gerrard 2000).

Soils in active floodplains can be very spatially variable, as they are subjected to the soil forming factors not only in situ, but also to those occurring throughout the 
watershed upstream (Vannote et al. 1980, Lewis et al. 2003). Climate effects include weathering processes of upland parent material, continued weathering that occurs during transport in the stream, and successive flooding events after deposition. Riparian soils receive organic input during runoff from upslope sources, from within the riparian zone due to plant and animal life cycles and activities, and from upstream sources during flooding (Vannote et al. 1980, Gregory et al. 1991, Mitsch and Gosselink 2000). The normal effects of topography on soil formation, generally associated with gravity and near surface processes related to slope shape, length, and gradient, may be regularly disrupted by flooding, which re-deposits sediments at higher locations on the banks of floodplains (Walling and He 1997). Downstream transport, flooding, and sedimentation processes inherent in riparian zones result in floodplain parent material potentially composed of the parent material of the entire watershed upstream of any given point in the floodplain (Vannote et al. 1980, Gerrard 2000). Watersheds with highly variable geology produce sediment with variable chemical and physical properties. Some of this sediment ultimately washes into streams and is deposited in floodplains downstream. The repeated cycle of flooding, scouring, erosion and deposition in erosional river-floodplain systems keeps most associated soils in a constant state of early soil development with a high degree of coarse fragments (Mitsch and Gosselink 2000). Mass wasting events of older soils upslope and upstream can result in deposits of material in floodplains with chemical and physical characteristics of much older soils. However, because of repeated 
disturbance of soil forming processes, these soils often exhibit poorly developed or no O or B horizons (Gerrard 2000).

The dynamic nature of floodplain processes that affect soil development results in riparian soils with highly spatially variable properties, many of which influence vegetation (Gregory et al. 1991, Bayley 1995, Florsheim and Mount 2002). This study will address differences in soil texture, soil $\mathrm{pH}$, soil surface slope gradient, and depth of the A horizon, and their relationships to herbaceous and sapling woody vegetation in an active floodplain (1-year flood frequency) of a free-flowing arid lands river. I chose these factors because previous studies have identified them as potentially significant soil factors related to vegetation (Willems et al. 1997, Chambers et al. 1999, Law et al. 2000, Dwire et al. 2000); because they can be studied within the available time, budget, and resources; and because they can produce valuable information about fine scale differences within the riparian zone (Bayley 1995, Law et al. 2000). These soil features display high degrees of heterogeneity in riparian landscapes, and present an opportunity to study a range of conditions and their relationship to riparian wetland plants (Harris 1987, Dwire et al. 2004, Law et al. 2000).

Soil texture is the relative proportion by weight of sand, silt, and clay. Sand particles range in size from $2 \mathrm{~mm}$ to $0.05 \mathrm{~mm}$. These relatively large particles make up the general structure of soils (Gerrard 2000). Sandy soils are highly permeable, have large pore spaces and high hydrological conductivity (Dingman 2002). They are also more susceptible to evaporation immediately following precipitation events (Dong et 
al 2003). Silt particles range in size from $0.05 \mathrm{~mm}$ to $0.002 \mathrm{~mm}$, while particles smaller than $0.002 \mathrm{~mm}$ are considered clay (Gerrard 2000). Riparian soils with higher concentrations of silt and clay retain nutrients and water more effectively than sandy soils, with soil total organic carbon and total nitrogen highly correlated with fine particle concentration (Bechtold and Naiman 2006). However, soils with particularly high clay concentrations can exhibit reduced aeration, and more easily become waterlogged (Gerrard 2000, Dingman 2002, Aringhieri 2006). Soil water and oxygen availability are both important to plant survival. Individual species may have particular adaptations, such as development of pore space in cortical tissues to counter anoxia, or reduced stomatal conductance to minimize water loss when soil water is restricted (Smith et al. 1991, Mitsch and Gosselink 2000). This variety of adaptations to stressful conditions results in a range of tolerances to soil water and soil oxygen conditions.

Soil $\mathrm{pH}$ and the mechanisms that determine soil $\mathrm{pH}$ affect plant growth by changing the availability of nutrients. In wet climates and regularly flooded areas, water and organic acids filter through the soil column, replacing the important plant macronutrients calcium, magnesium, and potassium with hydrogen ions, thus decreasing soil $\mathrm{pH}$ (Gerrard 2000). Low $\mathrm{pH}$ in soils also affects the availability of other nutrients that may be present in the soil through biological mediators and by direct interaction with nutrients. $\mathrm{pH}$ strongly influences soil microbial populations that regulate the availability of nitrogen and other macronutrients (Parkin et al. 1985, Blosl and Conrad 1992). Acidic conditions cause dissolution of iron and aluminum minerals, 
which precipitate with and immobilize phosphorus, making it unavailable to plants (Adams and Odom 1985). On the other hand, low $\mathrm{pH}$ makes aluminum and many micronutrients, such as iron, manganese, zinc, boron, and copper more available to plant uptake (Sims and Patrick 1978). This creates a potentially toxic environment for plants that are not adapted for such conditions. For example, plants without specific adaptations to either tolerate aluminum in plant tissues, or to avoid taking up soluble aluminum may experience direct metabolic toxicity or inhibited ability to absorb iron in a high aluminum environment (Raven et al. 1998).

The surface slope gradient of a soil influences the movement of sediment, water, and nutrients over and through the soil. Steeper slopes are often associated with greater erosion rates, but the constant deposition in active floodplains may negate this effect (Stromberg et al. 1997, Bendix and Hupp 2000). All other things (such as soil texture and surface roughness) being equal, soils with more moderate surface slope gradients will produce less runoff and allow more infiltration of water into the soil than those with steeper slopes (Nassif and Wilson 1975, Wilcox et al. 1988, Wilcox and Wood 1989, Dingman 2002). During unsaturated conditions, which floodplain soils in semiarid and arid landscapes experience much of the year, water movement within the soil is generally dominated by lateral downslope movement (Weyman 1973, Harr 1977, Ticehurst et al. 2006). Of two soils with similar hydrological transmissivity properties, the one with a greater surface slope gradient will experience more lateral downslope movement of soil water (Weyman 1973, Anderson and Kneale 1980). This movement of water results in lateral flushing of soil nutrients (Pinder and 
Jones 1969; Anderson and Burt 1982, Hornberger et al, 1994). Lateral flushing can alter the nutrient availability of soil at a given point (Bridge and Johnson 2000). It can also result in accumulation of salts and ions that affect electrical conductivity and cation exchange capacity (Fritsch and Fitzpatrick 1994, Seelig and Richardson 1994), and of metals that may be toxic to plants that do not possess adaptations to such conditions (Litaor 1992). Slope gradient effects on the movement and availability of soil water and nutrients to which riparian wetland plants may be sensitive.

Due to repeated scour and deposition of sediment, active floodplains often have poorly developed soils that lack O or B horizons (Mitsch and Gosselink 2000). The depth of the surface or A horizon can exert influence over the movement and availability of water and nutrients within this horizon, in which the roots of most herbaceous and woody sapling plants are active. Shallow surface horizons, while having less vertical space in which to store water over time, will become saturated more quickly with precipitation or flooding than will deep surface horizons (Dingman 2002). Saturation can either come from rising groundwater below, or can occur because of an abrupt decrease in permeability between the surface and subsequent horizons that prevents infiltrated precipitation or floodwater from draining out of the bottom of the surface horizon. This potentially creates a temporary perched water table that can reach the soil surface (Law et al. 2000, Mitsch and Gosselink 2000, Dingman 2002, Dwire et al. 2004). Saturated flow dynamics (vertical and lateral) are markedly different than unsaturated flow dynamics in most soils (Weyman 1973, Harr 1977). Breaks in permeability in the soil profile are often associated with increased lateral 
movement of soil water during unsaturated conditions, and a shallow surface horizon over a less permeable horizon is likely to experience such conditions more quickly after precipitation or flooding events than a deeper surface horizon (Harr 1977). As discussed previously, this can affect nutrient, water, and salt movement and accumulation, with shallower surface horizons experiencing more lateral flushing. Concentrations of dissolved organic carbon, dissolved organic nitrogen, and nitrate often decrease dramatically, even exponentially, with depth in the soil profile (Willems et al. 1997, Lathja et al. 2005, Weiler and McDonnell 2006).

A shallow surface horizon in close proximity either to the water table or to a less permeable lower horizon experiences more frequent saturation, creating stresses that make wetland plants with adaptations to saturated conditions more competitive at that site (Dwire et al. 2000, Law et al. 2000). During unsaturated conditions, a shallow surface horizon is often associated with less distance to the water table (Castelli et al. 2000, Dwire et al. 2000). Capillary action and tension produced by plant roots can move water from the water table into the lower parts of the surface horizon, making it available to wetland plants that are dependent on large amounts of available water during unsaturated conditions (Smith et al. 1998, Dingman 2002). This can be particularly important in semiarid and arid regions where climatic conditions place additional stress on wetland plants (Smith et al. 1998, Patten 1998, Castelli et al. 2000). 


\section{Need For Further Study Of Fine-Scale Floodplain Physical And Riparian Vegetation Dynamics}

Flooding is the overwhelming driver of hydrology in riparian and floodplain ecosystems (Richter and Richter 2000). Flood power, duration, timing, horizontal extent, and depth determine geomorphic surface features, create heterogeneous physical environmental landscapes, and provide significant inputs of water into the terrestrial hydrologic system (Bayley 1995, Schade et al. 2005, Walling and He 1997, Smith et al. 1998). Numerous studies have examined zonal distribution of riparian plants related to large-scale factors that influence hydrology, such as flood duration, distance from an active stream channel, and height above the active stream channel (Harris 1987, Hughes 1997, Stromberg et al. 1997, Castelli et al. 2000, Dwire et al. 2004). Other studies have identified relationships between riparian vegetation and certain key environmental variables, many of which influence fine scale hydrology and other features that affect plant species success (Weyman 1973, Willems et al. 1996, Shafroth et al. 1998, Chambers et al. 1999, Sharp 2002). These studies provide a strong foundation of information for studying and understanding the environmental factors that influence riparian vegetation. However, these and many other studies either approach the annually flooded portions of floodplains as single units, focus only on broad spatial patterns of vegetation in a floodplain related to coarse scale hydrology, or focus entirely on fine scale relationships between plants and environmental variables, without regard to lateral position (e.g., near to or distant from the channel) in the floodplain. The spatial heterogeneity of floodplain environmental 
variables is well established, but there has been little investigation of the relationships between these variables and plants in distinct locations within the floodplain. This study is intended to determine whether an annually flooded, unmanaged floodplain functions as a single ecological unit from the upper extent of annual flooding to the stream edge at baseflow; and to examine and compare the relationships between several fine scale environmental variables - soil texture, soil $\mathrm{pH}$, surface slope gradient, and depth of the A horizon - and riparian vegetation between the upper and lower extents of the floodplain subjected to annual flooding. These two zones of a floodplain experience two different flood regimes, and therefore two different coarse scale hydrological inputs that may affect the behavior and relationships of dynamics between plants and fine scale environmental controls. 


\section{METHODS}

\section{Study Area}

\section{Geographic Setting and Human Use}

This study was conducted along the main stem of the John Day River and the first four river miles of the North Fork John Day River in northeastern Oregon (Figure 1 and Figure 2). The river system consists of the main stem, North, Middle, and South Forks of the John Day River, and numerous smaller tributaries. Over the course of more than 500 total river miles, there are no impoundments. At 284 river miles long, the main stem of the John Day River is the second longest free-flowing river in the continental United States. The river system drains nearly 8100 square miles, and flows through eight counties. On the course to its mouth at the Columbia River, it passes through a number of small communities, the largest of which is John Day, population 1840. The total human population of communities on or near the river is approximately 7065 (USDI-BLM 2000). While the river system drains approximately $8.5 \%$ of Oregon's total land area, the population of the basin represents only $0.2 \%$ of Oregon's total population. 
Figure 1. Location of John Day River Basin

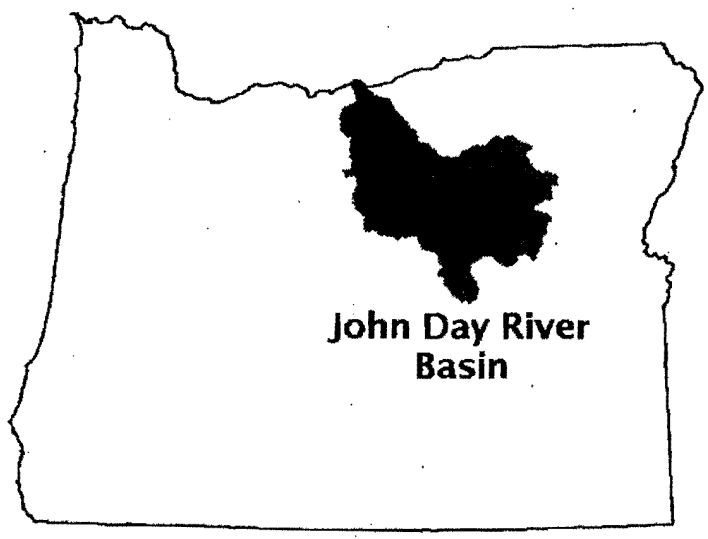

OREG O N

Figure 2. John Day River Basin and Study Area Overview

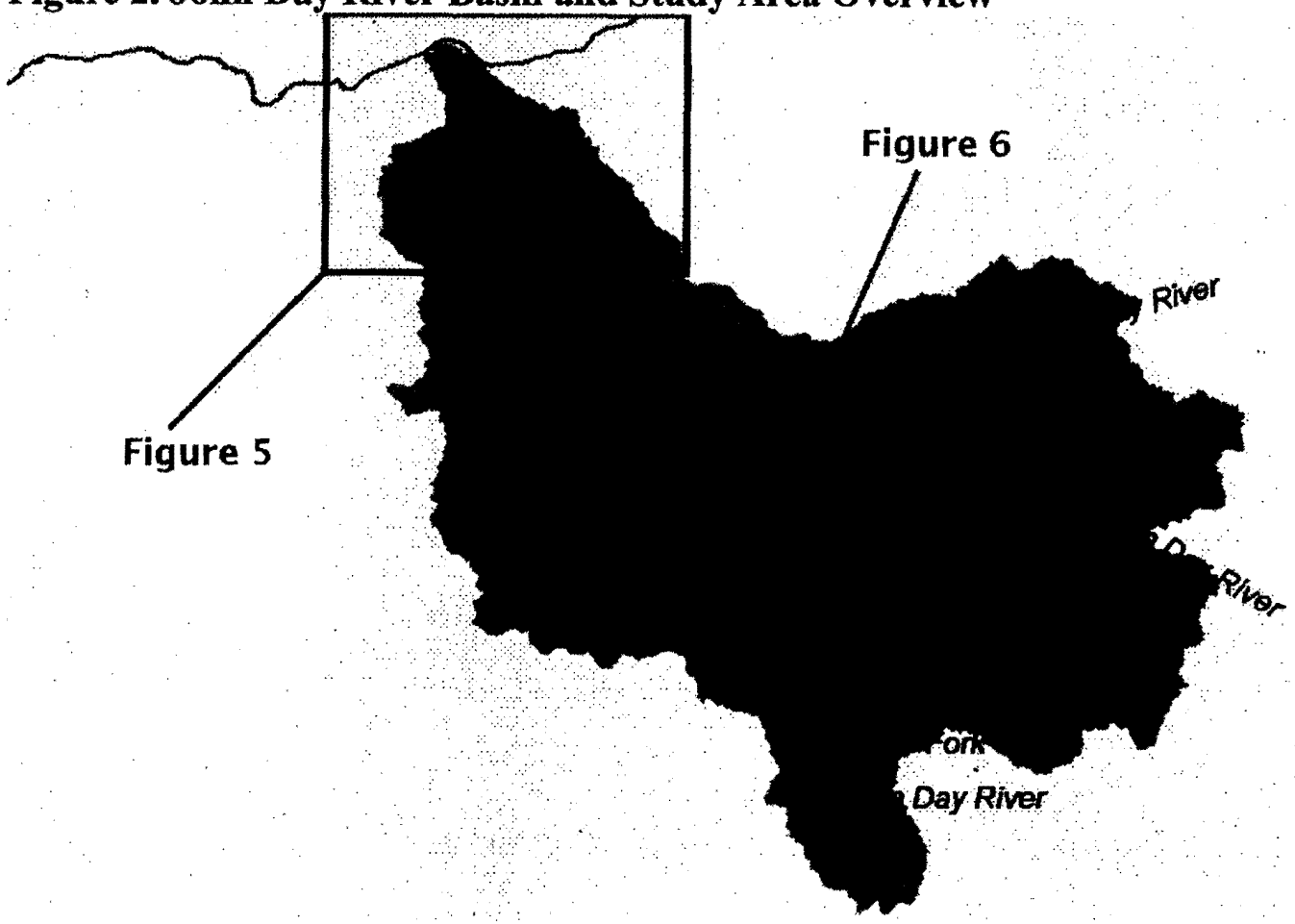

Native Americans used the John Day River basin for fishing, hunting, trapping, and gathering activities for at least 10,000 years prior to European discovery of the region (USDI-BLM 2000). The European moniker for the John Day River was 
bestowed to "honor" a member of Jacob Astor's party who became separated from the rest of his group while traveling down the Columbia River toward the Pacific Ocean in 1811-12. John Day never explored the river that bears his name. Rather, it was at the mouth of the river that members of his party found Mr. Day robbed, stripped of his clothing, and abandoned by local Native Americans (Beckham and Lentz 2000). During this time European fur trappers began to use the area. Ensuing hostilities between the Native Americans and would-be settlers resulted in military action and the displacement of natives to reservations. Homesteaders began to settle on the banks of the John Day River, taking advantage of the fertile valley bottom sediment and of irrigation water from the river (USDI-BLM 2000). Several gold discoveries in the surrounding Blue and Strawberry Mountains led to an expansion of the population and the economy of the basin. The resulting growth of settlements along the river spurred development of the lumber industry in the same mountains. Cattle and sheep ranching on the arid grassy slopes around the river proved to be a more enduring industry that began in 1862 and persists today (Beckham and Lentz 2000). The other persisting industries include crop agriculture and recreation. Grass and hay products along the basin bottom are the primary irrigated crops of the region. River rafting, fishing, hunting, camping, and wildlife observation are the most common recreational pursuits on the river (USDI-BLM 2000).

The John Day River is classified as Scenic, State Scenic, and Wild and Scenic at various stretches. Annual mean discharge is slightly more than 1.5 million acre-feet. This discharge varies from as low as 1 million to as high as 2.4 million acre-feet per 
year. Five special status fish species - Mid-Columbia steelhead (Threatened), Bull trout (Threatened), Interior Redband trout, Westslope Cutthroat trout, and Pacific lamprey (Sensitive) - occupy the river (USDI-BLM 2000). All Wild and Scenic

sections of the river are on Oregon Department of Environmental Quality's 303(d) list of affected waters for temperature. Several segments are also listed for bacteria, flow modification, and bacteria. Soils and geomorphological processes within the river system contribute to naturally high sediment loads that can affect water quality properties. However, most of the water quality problems in the basin stem from continued livestock grazing and water withdrawals, the cumulative effects of timber harvest and road building, and from historical mining and dredging activities (OWRD 1986, ODEQ 1998).

\section{Geology, Soils, and Vegetation}

The entire John Day River system drains nearly 8100 square miles of geologically diverse interior plateau. Elevations range from 265 feet at its confluence with the Columbia River at River Mile 218, to over 9000 feet in the Strawberry Mountains. Much of the area's underlying geology was covered by flood basalt flows originating in central and eastern Oregon during the relatively recent Miocene, between 20 and 15 million years ago. These flows are the most pervasive surface geology in the area today. Only in areas of substantial erosion or at particularly high elevations is other bedrock currently exposed. The area has been subjected to considerable erosion since the most recent basalt flows ceased approximately 12 
million years ago. Rich, deep Pliocene fill now covers many of the valley floors (Orr et al. 1992, Alt and Hyndman 2001).

Where either the underlying geology was not covered by basalt, or erosion has exposed the underlying rocks, there is great diversity of geologic formations. The Blue Mountain province, which contains the headwaters and substantial portions of each major fork of the John Day River, contains layered bands of exotic terranes. These terranes originated in a marine environment far from their present location, when the ancient shoreline was far to the east of its current location. During the Triassic period 200 million years ago, island blocks were transported great distances from their locations far to the west in the Pacific Ocean, and as far south as 18 degrees north latitude, and accreted to the North American craton. In all, five major terranes, each with a distinctive suite of rocks, have been recognized in this province (Orr et al. 1992).

The North and Middle Forks of the John Day River drain portions of the Elkhorn and Blue Mountains. These ranges contain not only basalt from several separate origins and flows, but also exposed granite, schist, rhyolite, andesite, and a variety of sedimentary rocks. The South Fork drains portions of the Ochoco and Aldrich Mountains. While basalt flows cover much of the lower reaches of these mountains, at higher elevations there are exposed Triassic and Jurassic sedimentary rocks (sandstones and shales), rhyolite, peridotite, gabbro, and serpentine rocks (indicating metamorphism). The main stem of the John Day River originates in the 
Strawberry Mountains. Again the ubiquitous basalt flows are present here, along with peridotite, serpentine, sedimentary rocks, and gabbro.

Another important feature of geologic history in the area is a series of explosive volcanic eruptions that deposited substantial loads of ash. This resulted in formation of rocks comprised of welded ash and occasionally mud. These features can be seen prominently in the John Day Fossil Beds National Monument, through which the river runs. The fossil beds preserve an array of plant and animal species from 54 to 6 million years ago (Orr et al. 1992, Alt and Hyndman 2001, Beckham and Lentz 2000).

Fossil plant species, along with bright red laterite soils preserved between basalt flows, indicate that during this time the John Day River basin had a tropical climate. The modern climate is quite a bit dryer and more temperate. Average annual precipitation in the river basin ranges from 9 inches at the lower elevations to 50 inches at the higher elevations, and is concentrated in the winter months. The river system is driven by snowmelt, so peak flows are generally in the late spring. Mean annual temperature is 58 degrees Fahrenheit in the lower basin and 38 degrees Fahrenheit in the upper basin, while actual temperatures vary from subzero to over 100 degrees Fahrenheit throughout the basin (USDI-BLM 2000).

The John Day River basin's non-crop vegetation varies with elevation and landform. The higher elevations receive the most precipitation and can host fairly deep soils. About half of the uplands in the basin are covered with forestland. South slopes are drier and host ponderosa pine-mountain mahogany/elk sedge-Idaho fescue 
communities. Wetter north slopes support Douglas-fir/elk sedge communities. The middle elevation uplands have more sparse vegetative cover. These slopes have been subject to substantial erosion throughout the Pleistocene and Quaternary due to a combination of lack of plant cover and large infrequent storm events. Soils are thin and support a type of shrub steppe community of sagebrush and western juniper with cheatgrass, Idaho fescue, and bluebunch wheatgrass (Franklin and Dyrness 1988, USDI-BLM 2000). Figure 3 illustrates typical landforms and vegetation of the John Day River Basin.

High erosion rates during modern geological history and the geologic variety of the plateau has contributed to a variety of soil types that make up the fluvial deposits on which modern valley floor crops and riparian vegetation grow. The soils tend to be silt loams with varying texture distributions and chemical properties. Most are well drained to very well drained (Macdonald et al. 1964, Hosler 1977). On riverine terraces no longer subjected to regular flooding, the soil is deep, but the vegetation is xeric, dominated by sagebrush and annual grasses, with some riparian plants represented where occasional floods influence the soil hydrology (USDI-BLM 2000). It is on these extensive riverine terraces with their deep soil that irrigated agriculture has displaced much of the native vegetation, particularly upriver from the community of Spray (River Mile 170). 


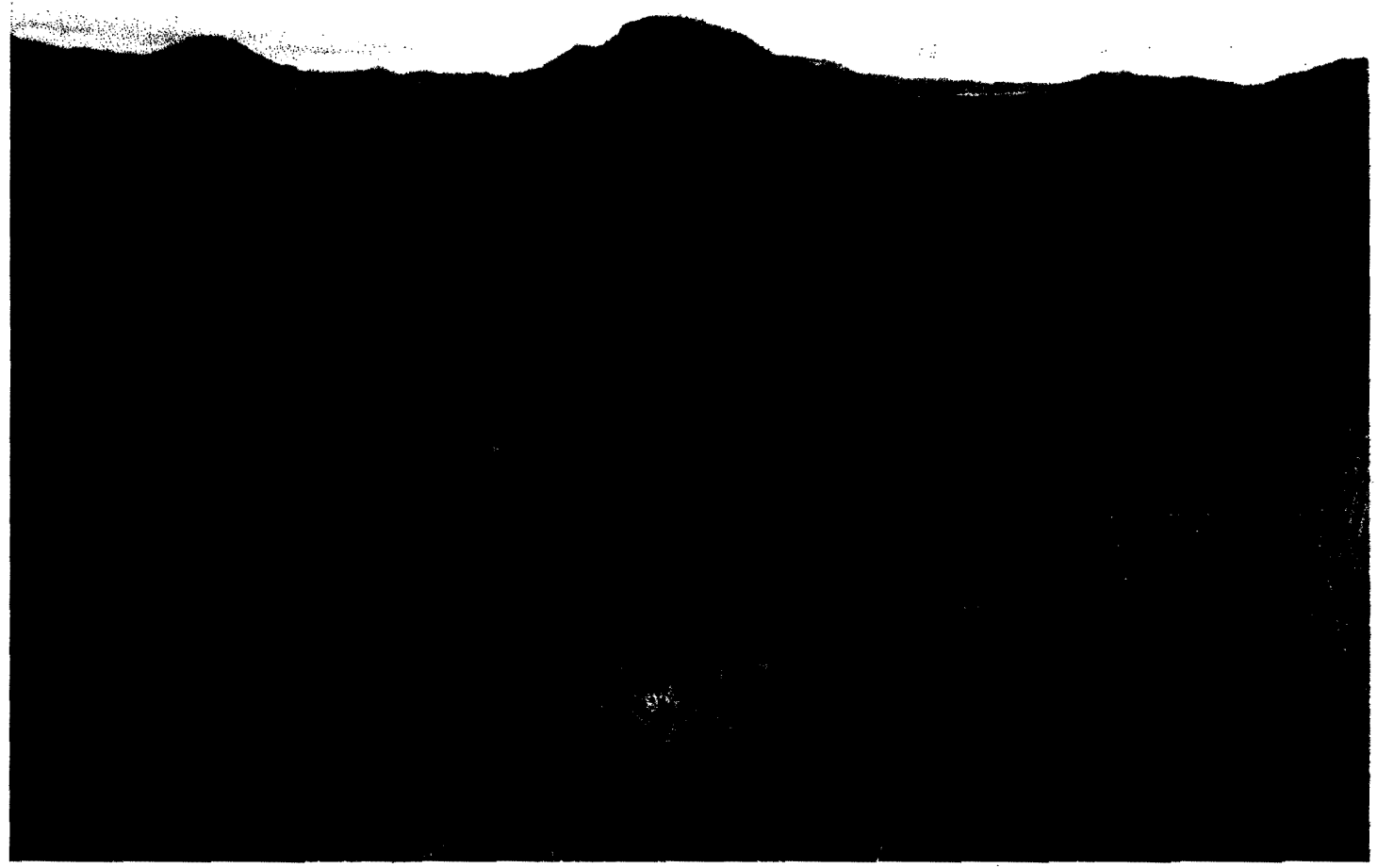

Riparian vegetation, where not replaced by agriculture, exists throughout the John Day River basin wherever the soil is inundated by the river for some portion of the growing season. Floods generally recede, leaving the riparian zones dry by midsummer. Common riparian plant communities include cottonwoods, serviceberry, alder, and annual grasses and forbs above the normal annual high water level. Willow, sedges, rushes, and a variety of forbs and grasses are common within the reaches of annual flooding (Franklin and Dyrness 1988, USDI-BLM 2000). Cattle grazing on private and public land is extensive in this drainage. For many years cattle grazed 
indiscriminately in almost all of the riparian areas. By 1980 land managers had fenced off many tracts of riparian wetland on public land. Photographic monitoring over time has shown a dramatic and fairly rapid return of native riparian vegetation, including sensitive willows, which had at one point become extirpated from many miles of riverside habitat (USDI-BLM 2000). Figure 4 illustrates a typical riparian landscape along the John Day River.

\section{Figure 4. Example of John Day River Riparian Zone, Near Spray, Oregon}

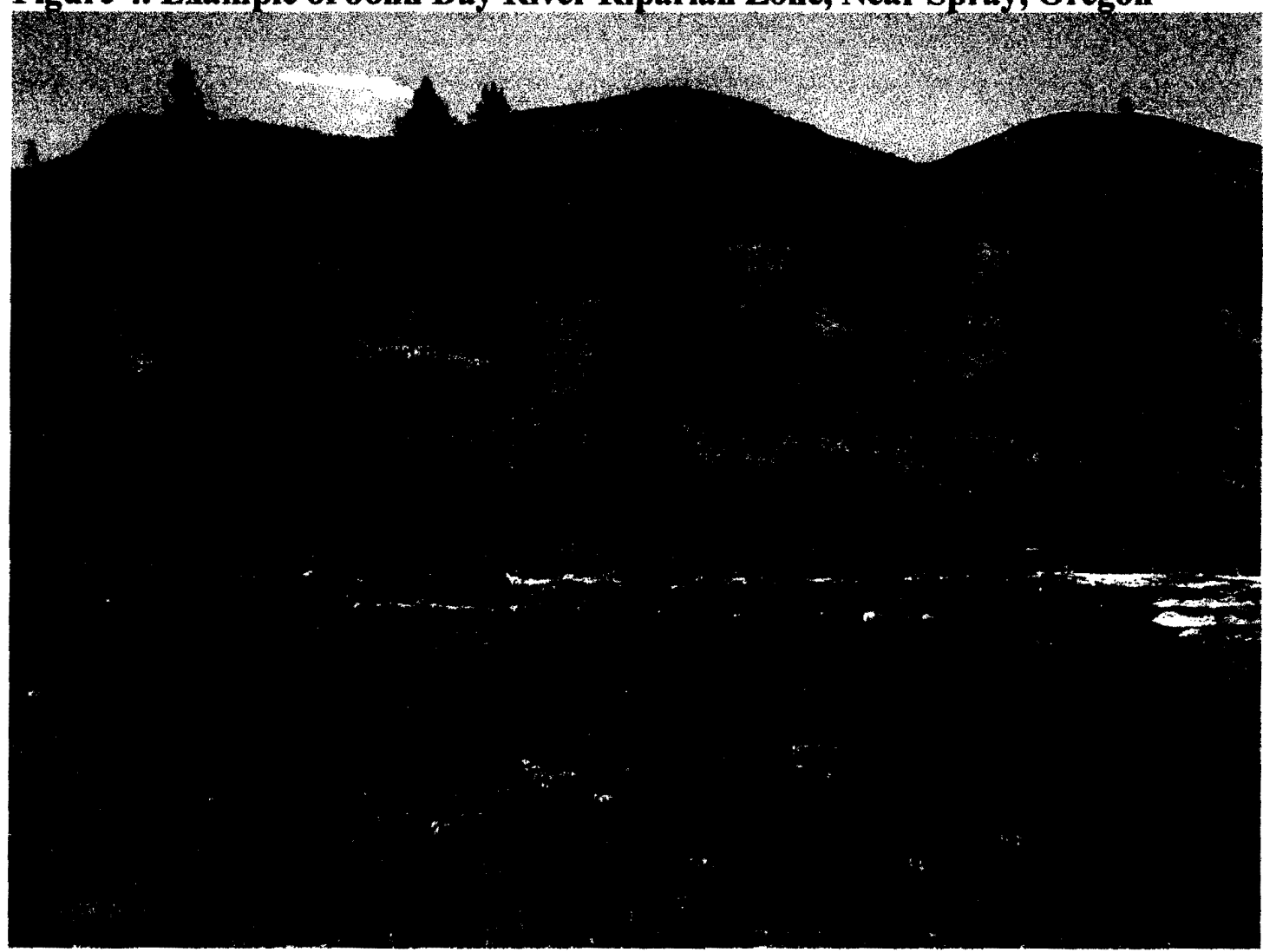




\section{Site Selection}

Sites were selected to represent random, non-paired samples in two different portions of the floodplain that would be subjected to annual flooding. Potential sample sites were established by studying aerial photographs and topographic maps, and by site visits. Final site selection was based on a number of criteria intended to minimize external disturbances, such as cattle grazing and active vegetation management activities. The upper floodplain samples were bounded upslope by the average annual flood extent for 2 consecutive weeks during the growing season, based on 75 years of stream flow data collected by the USGS. The lower floodplain was bounded downslope by the average annual flow between July 1 and November 1 . Final sample sites were selected only if they met the following criteria:

- Slope is less than $100 \%$

- Cattle have been excluded since at least 1999

Riparian zones that receive cattle exclosures recover in as few as 2 years, and generally within 5 years (Rickard and Cushing 1982, Kaufman et al 1983). Most of the riparian zones on the John Day River that were fenced as of the 1999 surveys included in a 2000 Environmental Impact Statement had actually been fenced since at least 1988 (USDI-BLM 2000).

- No known active restoration, such as planting, has occurred in the last 10 years 
- Located on BLM property, to which I had access and on which I had permission from the land manager to conduct my study

Most of the land near the John Day River is privately owned. The National Park Service administers several units of the John Day Fossil Beds National Monument, through which the river flows. Clyde Holliday State Park is the only state holding on the river. The Bureau of Land Management administers the remaining public land (USDI-BLM 2000).

- Within the limits of average annual flood extent, as determined according to methodology below

All sites were located on public property within the floodplain of the main stem of the John Day River between River Mile 0 and 187 (further upstream the river enters National Park and private holdings), and the first four river miles of the North Fork John Day River. I started by examining aerial photos and 7.5" topographic maps and making a list of what appeared to be suitable stretches of floodplain. I then crossreferenced the potential sites with allotment records shown in the 2000 John Day River Proposed Management Plan EIS (USDI-BLM) to ensure that each had been protected from grazing since at least 1999 and that no active vegetation management activities had been undertaken. I then visited the sites and made a list of floodplain stretches that were actually suitable based on the above criteria. I numbered and measured each candidate reach to the meter, using a GPS unit and field measuring tape. Each stretch was divided into 1-meter segments along an imaginary straight line 
running parallel to the stream for the entire reach length. Each point between two theoretical 1-meter segments would potentially serve as the center of a single random one square meter quadrat. I used a random number generator to produce 80 random numbers, corresponding to 40 sites in both the upper and lower active floodplain zones. No numbers were randomly selected twice. My intent was to conduct the study using 30 sites in each zone, so with 40 possible sites I had backup options if a site proved to be unusable while I was in the field. Several randomly selected points proved inaccessible, had a slope greater than $100 \%$, or otherwise did not meet the criteria for inclusion in the study. Ultimately I identified and selected 60 total sites, 30 each in the proposed upper and lower riparian zones. Figure 5 and Figure 6 illustrate locations of study sample points. Table 1 identifies the sites located in each segment.

Figure 5. Study Site Locations (1 of 2)

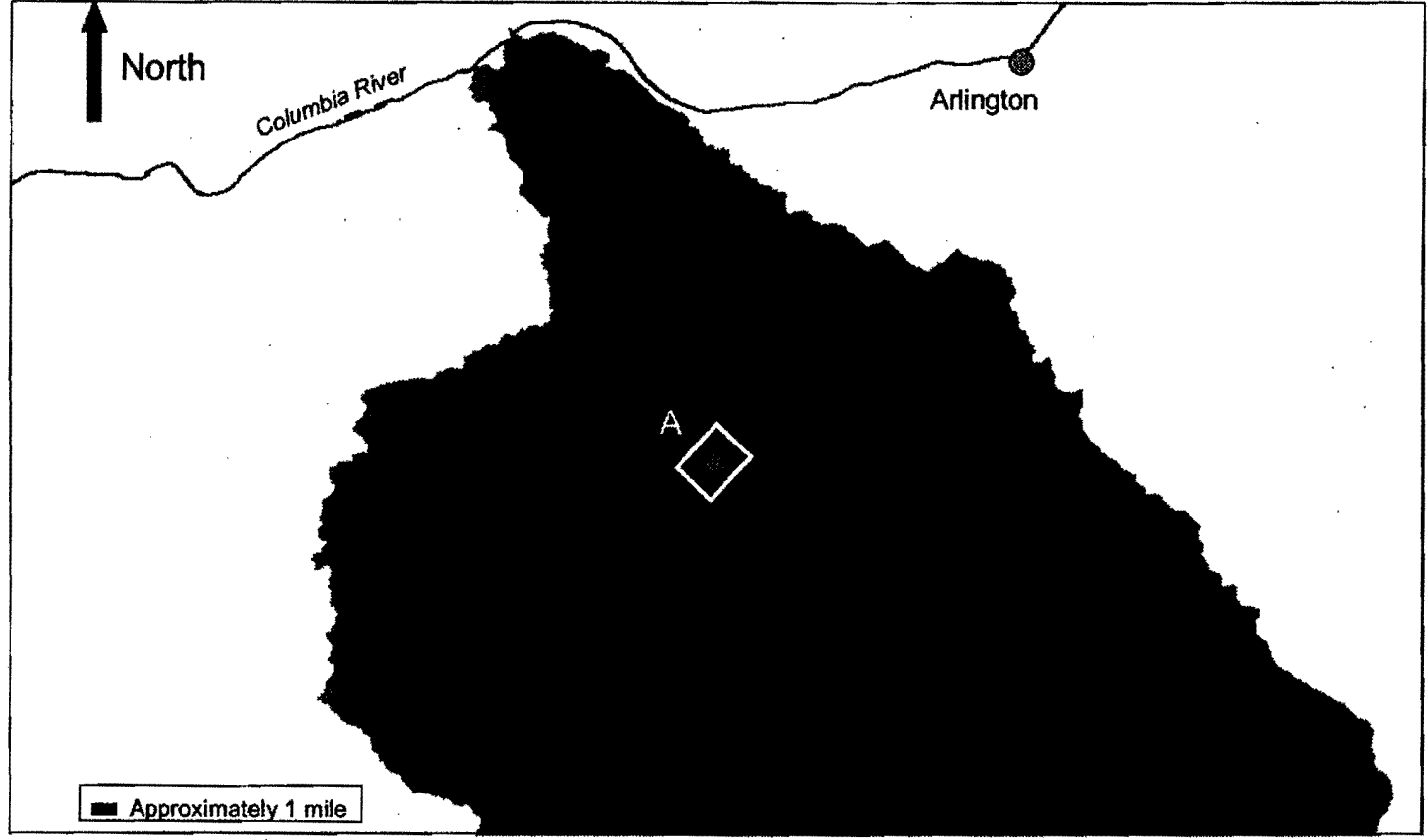


Figure 6. Study Site Locations ( 2 of 2 )

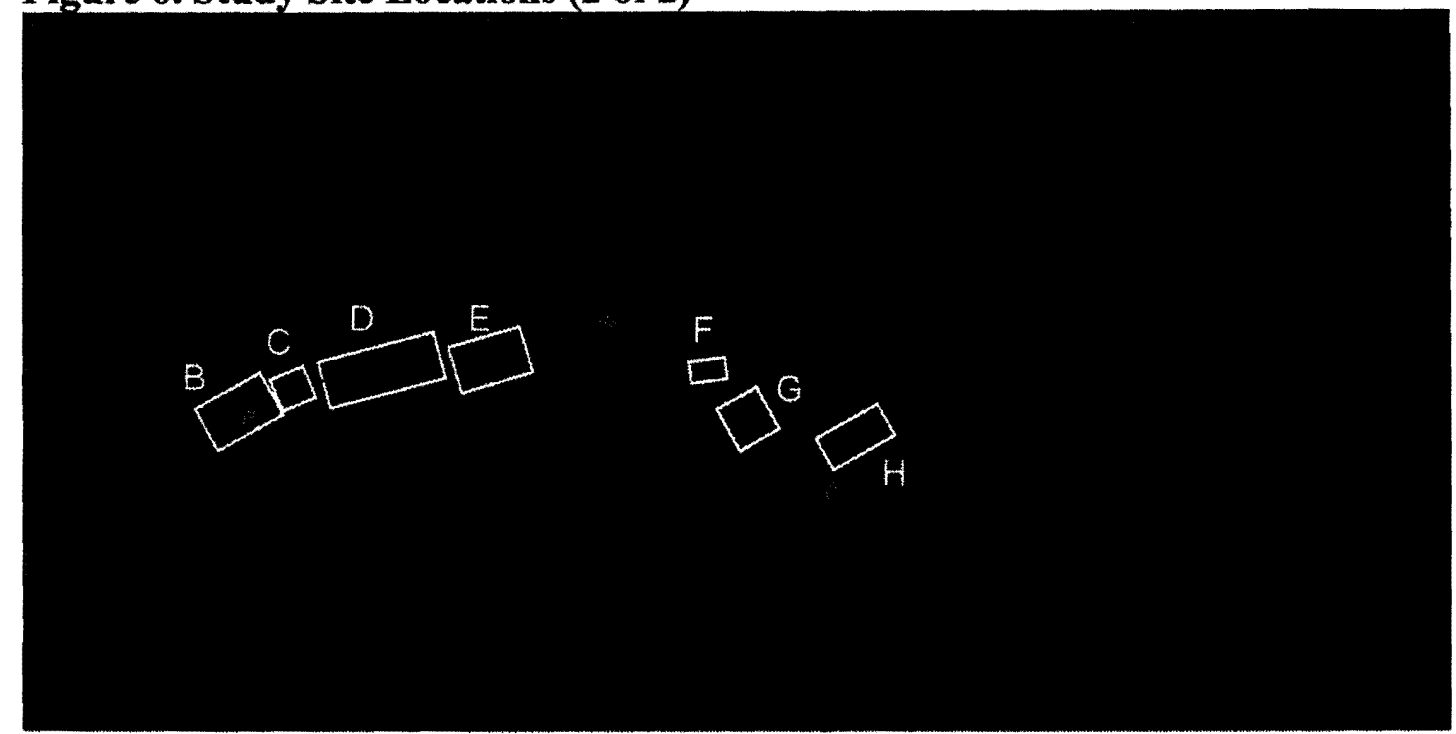

Table 1. Location of Upper and Lower Sample Site Numbers

\begin{tabular}{|l|l|l|l|l|l|l|l|l|}
\hline Segment & A & B & C & D & E & F & G & H \\
\hline $\begin{array}{l}\text { Upper } \\
\text { Sites }\end{array}$ & None & $\begin{array}{l}1-3, \\
13-18\end{array}$ & $10-12$ & $\begin{array}{l}4, \\
19-21\end{array}$ & $5-9,22$ & 23,24 & 25,26 & $27-30$ \\
\hline $\begin{array}{l}\text { Lower } \\
\text { Sites }\end{array}$ & 11 & $\begin{array}{l}7-10, \\
12,18\end{array}$ & 19,20 & $\begin{array}{l}3,21, \\
22\end{array}$ & $\begin{array}{l}4, \\
15-17\end{array}$ & $\begin{array}{l}13,14, \\
23,24\end{array}$ & $\begin{array}{l}1,2, \\
27-30\end{array}$ & $\begin{array}{l}5,6, \\
25,26\end{array}$ \\
\hline
\end{tabular}

The lowest flows on the John Day River occur between July 1 and November

1. The average flow at the Service Creek gage (Figure 6) during this period is approximately $315 \mathrm{cfs}$. For the lower riparian zone, I monitored flow rates of the John Day River at Service Creek on the USGS website (http://waterdata.usgs.gov/usa/nwis/uv?site no $=14046500$ ). On Friday, July 23, 2004, the gage read $351 \mathrm{cfs}$, which I determined to be close enough to the ideal $315 \mathrm{cfs}$ to establish the water line at average low flows in the field. On July 24,2004 , I visited my randomly selected lower riparian points. I drove a piece of rebar with pink flagging tied to the top into the substrate at the water's edge, leaving no metal above 
the surface, with a small bit of flagging protruding. I also took a GPS reading at each point. The center of each quadrat was placed 1.5 meters upslope from the water's edge at approximately $315 \mathrm{cfs}$, allowing me to measure the slope of the floodplain one meter below the downslope edge of the quadrat (Figure 7). At several locations the surface soil horizon was too shallow to get even a short segment of rebar into the ground sufficiently. In such instances, I conducted all of my field sampling at that time. Otherwise I returned to each site for sampling over the course of the following month. One criterion of wetlands is soil saturation or inundation for at least 2 weeks per year during the growing season. As the hydrology of the John Day River is driven by snowmelt, peak flows occur in April and May. I selected $4620 \mathrm{cfs}$ to represent the annual high flow for the riparian wetland. Over 75 years of data, the river floods above $4620 \mathrm{cfs}$ an average of $20 \%$ of the year. Between 1929 and 2004 the average date at which the river discharges at this rate is May 28. According to the State Climatologist, the $80^{\text {th }}$ percentile last day of spring frost for Wheeler County (in the middle of the John Day River basin) is May 12, while the $80^{\text {th }}$ percentile first day of autumn frost is October 23 (http://www.ocs.orst.edu/county climate/Wheeler files/Wheeler.html ). Therefore a flood between May 12 and May 28 may reasonably be considered a twoweek annual flood during the growing season. For the upper riparian zone, I monitored flow rates of the John Day River at Service Creek on the USGS website (http: //waterdata.usgs.gov/usa/nwis/uv?site no $=14046500$ ). On Wednesday, April 27,2005 , the gage read $4600 \mathrm{cfs}$. On Thursday, April 28,2005 , I visited my randomly selected upper riparian points. I drove a $33 \mathrm{~cm}$ piece of rebar with pink flagging tied to 
the top into the substrate at the water's edge, leaving no metal above the surface, with a small bit of flagging protruding. I also took a GPS reading at each point. After the flow had receded, the center of each quadrat was placed 0.5 meters downslope of each piece of rebar (see Figure 7). This made the upper edge of each upper riparian quadrat coincide with the upper extent of the $80^{\text {th }}$ percentile 2-week flood during the assumed growing season and ensured that the area contained in each quadrat was inundated for roughly the same period of time. Based on 75 years of data, the upper riparian sites are flooded an average of 55 days per year, 14 of which occur during the assumed growing season. By comparison, the lower riparian sites are flooded an average of 285 days per year, 86 of which occur during the assumed growing season. Lower riparian sites are flooded an average of 72 more growing season days per year than upper riparian sites.

Figure 7. Example of Site Locations

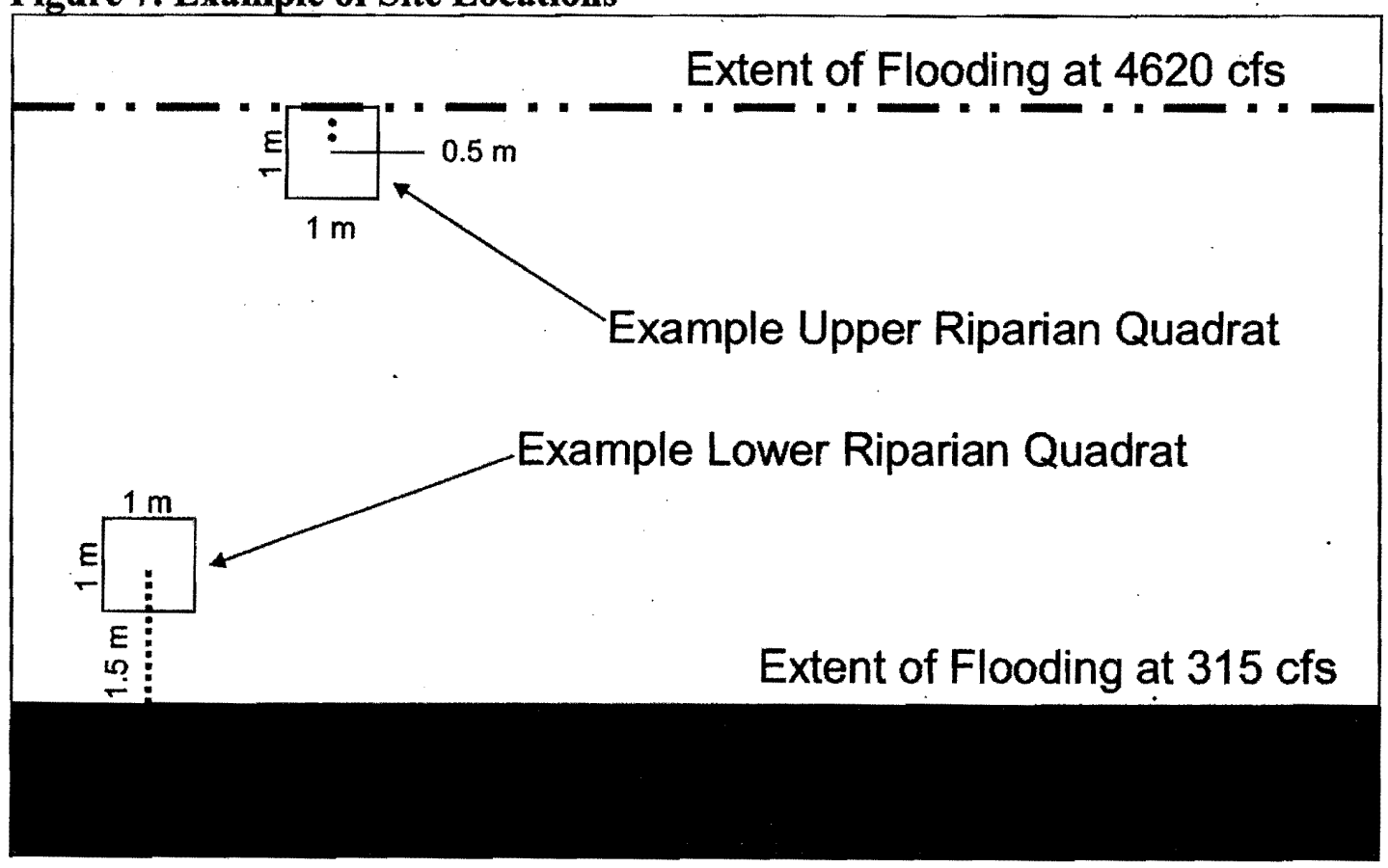


I took a GPS coordinate at the center of each quadrat. Upon completion of sampling procedures at each site, I removed the length of rebar marking the sampling location.

\section{Vegetation Sampling}

I conducted vegetation sampling in the lower and upper riparian zones in the summers of 2004 and 2005, respectively. For each sample site I placed a one-squaremeter quadrat frame so that the center aligned with the randomly selected points either upslope or downslope from each point, as described previously. Within each quadrat I identified all species and recorded cover of all herbaceous vegetation and sapling woody vegetation, by species, for each quadrat. Species identification and naming conventions followed Hitchcock and Cronquist (1973), Guard (1995), and Royer and Dickinson (1999). Cover was estimated in $1 \%$ increments up to $5 \%$, and in $5 \%$ increments thereafter (Daubenmire 1959). Because multiple layers of plant cover could exist in a single quadrat, the total coverage at times exceeded $100 \%$. Additionally, all species cover percentages were summed for the total riparian, upper riparian and lower riparian zones. The percent cover for each species was divided by the summed percent covers to determine the percent of total cover associated with each species. These percentages add up to $100 \%$. Each species identified was assigned a wetland indicator status, according to the US Fish and Wildlife Service's 1996 . wetland plants list for the Northwest region (USFWS 1997). In addition to recording 
coverage for individual species, aggregate coverage for each wetland indicator category (e.g. OBL, FACW, etc) was recorded.

This study was intended to focus on relationships between surface processes and plants and the ability of analyses at coarse and fine scales to detect such relationsips. Cover for more mature woody vegetation, which is likely to have deeper roots and to be less affected by fine scale surface processes, was not estimated. The criteria for excluding one of these plants were if they either exhibited secondary xylem development or exceeded $30 \mathrm{~cm}$ in height. Such vegetation was noted to aid qualitative site description, but was not included in any further analysis. Inclusion of sapling woody vegetation was deemed important to this study because several woody species, including Salix exigua, are considered indicative of a healthy riparian ecosystem, and land managers frequently manage toward development of such species (USDI-BLM 2000).

\section{Physical Environmental Factors: Field Sampling}

All field sampling for physical environmental factors was performed after completion of the vegetation analyses. Depth and wet color of soil horizons, distance to an impenetrable soil layer, and surface slope were measured using consistent techniques for all 60 quadrats included in the study. A soil sample was collected for laboratory analysis for each quadrat, as well.

A small hole was dug in the center of each quadrat until an impenetrable layer was reached. Depth and wet soil color of any horizons were recorded from this pit, 
using changes in color, texture, or structure as indicators of presence of a new horizon (Burns 1990). All pits revealed only an A horizon over an impenetrable C horizon. Approximately one-half gallon of soil was collected from each A horizon. For convenience, and following general sampling conventions, large cobbles were not included in the soil samples returned to the lab, although their presence was noted. Care was taken to ensure that samples included soil from throughout the vertical extent of the A horizon. If an A horizon was not deep enough to provide a full halfgallon, as much soil as possible was collected. Soil samples were placed into individual one-gallon zipper lock bags and transported to the laboratory for drying, weighing, and processing. Two additional holes were dug, one each on the upslope edge and the downslope edge of the quadrat. Distance to the impenetrable layer was recorded in all three holes. The three measurements taken at each site were averaged and recorded as the depth to the $\mathrm{C}$ horizon. Average slope of the floodplain surface was measured using two one-meter measuring sticks and a hand level. Slope measurements were taken over one meter upslope of each quadrat, within each quadrat, and one meter downslope of each quadrat. The one-meter slopes were recorded individually, but averaged over three meters for the statistical analyses.

\section{Physical Environmental Factors: Laboratory Procedures}

All laboratory analysis was conducted on the 60 soil samples collected from the A horizons in the initial soil pit for each quadrat. Each sample was air dried for four weeks prior to any further processing. Soil texture and soil $\mathrm{pH}$ were determined 
and recorded for each sample, using consistent methodology for all samples as described below. After drying, but before further analysis, dry soil color was determined for each sample. Soil texture analysis consisted of two stages: overall texture to determine the percent by weight of gravel, sand, silt, and clay; and texture analysis of the sand component only.

Soil texture analysis began with weighing each air-dried sample and subtracting the bag weight, to give a total collected sample weight. Cobbles within the soil column were noted on field data sheets, but were not retrieved from the field as part of the soil sample, and were not part of the soil texture analysis. Each sample was sifted through a U.S. Standard \#10 sieve ( $2 \mathrm{~mm}$ mesh). Mineral fragments captured by the sieve were considered gravel. The gravel from each sample was weighed, and the gravel weight was divided by the total sample weight to obtain the minimal value of percent by weight of gravel. Gravel from each site was set aside in a series of separate, labeled containers, leaving only the sand, silt and clay component in the sample containers. Large fragments of organic material were removed from the sieve and set aside in labeled containers unique to each sample to facilitate possible organic mater analysis in the future. However, soil organic content was not included in the final study.

The non-gravel component of each separate sample was homogenized in the bag. Approximately 50 grams (weighed to four significant figures) of the remaining soil sample was placed in a beaker with a small amount of water. $50 \mathrm{ml}$ sodium hexametaphosphate was added as a dispersant, and the entire solution was stirred and 
mixed. The slurry was allowed to sit for one hour to ensure dispersal of fine soil particles. This slurry was poured into a wetted US Standard \#230 sieve $(63 \mu \mathrm{m}$ mesh) placed in a funnel, with the funnel emptying into a large container. The slurry was . pushed through the sieve with a wash bottle, using no more than $900 \mathrm{ml}$ of water. The slurry was washed until the effluent was no longer visibly turbid.

The component trapped in the sieve contained the sand portion of the sample. The sieve and sand were placed in an oven and dried at $103^{\circ} \mathrm{C}$ for at least one hour. When the sand was dry, it was brushed into a pre-weighed beaker and weighed. The total sand weight was divided by the 50 gram sample weight to determine the percent by weight of sand.

The soils of the John Day River floodplain were shown to be generally quite sandy. Therefore, additional analysis of the sand component was carried out. The dried sand that did not pass through the $\# 230$ sieve in the initial sand-silt-clay analysis was passed through a series of sieves: US Standard $\# 30(600 \mu \mathrm{m}), \# 70(212 \mu \mathrm{m}), \# 120$ $(125 \mu \mathrm{m})$, and $\# 230(63 \mu \mathrm{m})$. Soil particles passing through the \#230 sieve were weighed, set aside, and added to the silt-clay solution for inclusion in the pipette method of determining silt and clay concentration. The weights of the sand that did not pass through each grade of sieve were divided by the exact 50 gram sample weight to determine the percentage by weight of each size of sand particles.

The clay-silt-water mixture, which included all particles passing through the wet and dry \#230 sieves, was placed in a 1 liter graduated cylinder, and water was added until the cylinder contained exactly 1 liter of materials. The pipette method of 
particle size determination was used, based on the rationale that the denser particles will sink deeper, faster than the less dense particles. The silt-clay-water mixture was agitated with a plunger for 1 minute prior to beginning the pipette extraction timer. $25 \mathrm{ml}$ pipette samples were taken without intermediate stirring, from varying depths at appropriate intervals, as described by Welch et al. 1979. The schedule and depth of withdrawals is shown in Table 2. Pipette contents were placed into pre-weighed beakers, which were dried in an oven at $103^{\circ} \mathrm{C}$ until all of the water evaporated, and then placed in a desiccator cabinet. Each beaker was weighed, and the total weight of the silt and clay components was determined and divided by the sample weight to give percent by weight for silt and clay.

Soil $\mathrm{pH}$ was determined using a Hanna $\mathrm{pH} 211$ Microprocessor pH Meter, according to manufacturer instructions. 10 grams from each original soil sample and $10 \mathrm{ml}$ of distilled water were added to beakers. Each mixture was stirred well and allowed to sit for 5 minutes. The $\mathrm{pH}$ meter was calibrated prior to taking readings. The meter's probe was placed in each sample for at least 30 seconds, or until the reading equilibrated to one decimal place. The $\mathrm{pH}$ for each sample was recorded to one decimal place. The probe was washed between samples to prevent cross contamination.

I initially determined the soil organic content by performing loss on ignition for each soil sample. However, the percent loss on ignition was very small (between $2.2 \%$ and $11.7 \%$ ), with little variation (mean $=6.4 \%$, standard deviation $=2.4$ ). No soils in the study area were found to be organic. Because of the minimal presence and 
lack of variation of soil organic content, percent loss on ignition was not included in any analyses for this study.

Table 2. Schedule and Depth of Withdrawals for Pipette Method

\begin{tabular}{|l|l|l|l|l|l|}
\hline Diameter Less & \multirow{2}{*}{$\begin{array}{l}\text { Diameter Less } \\
\text { Than }(\mu)\end{array}$} & Withdrawal & \multicolumn{3}{|l|}{ Withdrawal Time at $20^{\circ} \mathrm{C}$} \\
\cline { 5 - 7 } & Than $(\Phi)$ & Depth $(\mathrm{cm})$ & hr & min & sec \\
\hline 62.5 & 4.0 & 20 & - & - & 20 \\
\hline 31.2 & 5.0 & 10 & - & 01 & 54 \\
\hline 15.6 & 6.0 & 10 & - & 07 & 36 \\
\hline 7.8 & 7.0 & 10 & - & 30 & 26 \\
\hline 3.9 & 8.0 & 5 & 1 & 00 & 51 \\
\hline $1.95^{\star}$ & $9^{*}$ & 5 & 4 & 03 & 00 \\
\hline
\end{tabular}

*Clay particles

In summary, the following data set was developed for each of 30 lower riparian and 30 upper riparian sites:

- Herbaceous and sapling woody vegetation cover by species

- Herbaceous and sapling woody vegetation cover by wetland indicator status

- Basic soil profile, including wet and dry color

- Depth to impenetrable $\mathrm{C}$ horizon

- Slope one meter above, within, and one meter below each quadrat

- Overall soil texture - percent gravel, sand, silt, and clay

- Sand fraction texture

- Soil pH 


\section{Statistical Analysis}

Once all vegetation and physical environmental factor analyses were complete, the data were compiled and analyzed. Data were analyzed with a combination of univariate and multivariate methods. Univariate methods were used to directly test the null hypotheses presented for individual species or environmental variables, while the multivariate methods were used to further describe and understand the data. A P value of $\leq 0.05$ rejected the null hypothesis for all univariate statistical tests. A number of plant species were found at three or fewer sites and accounted for less than $1 \%$ of vegetation cover in either the upper or lower riparian zone. Combined, these species accounted for $3.27 \%$ and $4.45 \%$ of cover in the lower and upper riparian zones, respectively. These species, included in Table 4 in the "Results" section, were removed from the data set used for the statistical analyses. The remaining species, listed in Table 5 in the "Results" section, were labeled the "dominant species," and subject to statistical analysis.

Nine major data categories were established:

- Combined (upper and lower) riparian dominant species

- Combined (upper and lower) riparian total species, grouped by wetland indicator status.

- Combined (upper and lower) riparian environmental variables

- Upper riparian dominant species

- Upper riparian total species, grouped by wetland indicator status 
- Upper riparian environmental variables

- Lower riparian dominant species

- Lower riparian total species, grouped by wetland indicator status

- Lower riparian environmental variables

Each category was analyzed for normality of percent quadrat cover by species, with the Kolmogorov-Smirnov test, using MINITAB 13 software. Much of the data were not normally distributed. In some cases, a species or environmental variable would show normal distribution in either the upper or lower riparian zone, but not in the other. Several transformations were attempted, but failed to produce normal distribution. Whereas a few variables showed normal distribution in both zones, for the sake of consistency the non-parametric Mann-Whitney test was used to compare the medians of individual dominant species percent quadrat cover and individual environmental variables between zones (Zar 1999). A 2-sample t-test was then utilized to compare means for each of these sample sets. In each case, if the Mann-Whitney test rejected or accepted the null hypothesis, the t-test performed similarly. Using the slightly less powerful non-parametric test did not likely result in Type I or Type II errors. The plants grouped by wetland indicator status data were normally distributed, so a 2-sample t-test was used to compare means between zones for these groups. MINITAB 13 software was used for completing the Mann-Whitney and t-tests. These analyses tested the null hypotheses that there is no difference between the vegetation and the environmental characteristics of the upper and lower riparian zones. To further inform the discussion of riparian zones being studied and managed as a single unit, 
descriptive statistics were compiled for all variables in the upper and lower riparian zones, and in both zones combined.

Relationships between vegetation and physical environmental variables were analyzed using single linear regressions. The regression analysis determined a linear equation that fit a line to points in a scatterplot as closely as possible, by minimizing the mean square of residuals between data points and the line (Zar 1999). Percent of quadrat cover for each dominant species was compared to each environmental variable for the lower riparian zone $(n=30)$, the upper riparian zone $(n=30)$, and for both zones combined $(n=60)$. The process was repeated for species grouped by wetland indicator status compared to each environmental variable. The number of species and environmental variables resulted in 198 sets of comparisons, with three locations (upper, lower, total riparian) in each comparison, resulting in 594 total comparisons. For ease of visual analysis, tables were created that only display the results of the regressions that showed a significant relationship between species and environmental variables $(\mathrm{P} \leq 0.05)(\mathrm{A}-1$ through Table A-17 in Appendix A). The results for each such relationship include the $P$ value and adjusted $R^{2}$ value. The $P$ value indicates the significance of the regression test results. Analyses with $P$ values greater than 0.05 potentially occur randomly, while those less than or equal to 0.05 have a statistically significant relationship. $\mathrm{R}^{2}$ is an indicator of the amount of variation of response variable (individual species or wetland indicator status group) values that is explained by the independent (environmental) variable values. The results of the regression analyses identify the existence, nature, and significance of relationships between 
plants and environmental variables in each portion of the floodplain. These were then used to address the null hypothesis that the relationships between plants and environmental variables are the same in both the upper and lower riparian zones. Performing regressions for species cover compared to environmental variables for the entire riparian zone enables comparisons between this frequently used approach for riparian study with the zone method described in this study. Any given plantenvironmental variable combination may have a significant relationship in one zone but not the other, and this significant zonal relationship might be lost if all 60 data points (upper and lower) are analyzed together.

The riparian-wide analyses, with 60 sample points were less likely to be affected by single points than were the single zone relationships, which contained only 30 sample points. Relationships identified by the riparian-wide analyses and by the single-zone analyses were considered consistent with previous studies and the common riparian-wide approach, and were not subjected to further statistical analysis. Relationships identified in only one zone, but not the other, and not by the riparianwide regressions, were subjected to additional analyses to eliminate relationships that appear significant due only to the presence of one or more outliers. All such analyses were performed with the statistical software "R." First I calculated Cook's D for each of these relationships. Cook's $\mathrm{D}$ is a diagnostic measure that identifies sample points that exert particular influence on the results of a regression by performing a series of regression analyses, each of which eliminates a single sample point. The differences between residuals are then averaged, and individual sample points that are likely to 
change the outcome of the single linear regression significance are identified. If Cook's D identified such sample points for any given relationship, I deleted each such point from the dataset for that relationship and performed a new single linear regression. If the regression results still showed a significant relationship, then I performed the Cook's D analysis again. In each such case, with the initial influential points removed, the second Cook's D analysis did not identify new influential data points. All initial significant relationships for which Cook's D did not identify influential points, and all regressions that showed a significant relationship after influential points were removed, were retained as significant.

Each relationship that appeared to be significant in only one of the two zones, based on the initial regressions, was subjected to another set of analyses. The first analysis was a logistic regression to determine if the environmental variable involved could be used to predict the presence or absence of each species. This was based on a binomial generalized linear model, in which each data point was categorized based on the presence or absence of the species, regardless of the percent of quadrat cover. If this analysis found that the environmental variable alone was a significant predictor of the presence or absence of the species in question, then a second logistic regression was performed on the original percent of quadrat cover data. Each sample point with a cover percentage of zero was removed from the dataset for the species-environmental relationship, and the response values were compared to a Poisson distribution to determine the significance of the relationship for only non-zero data points. 
Multivariate analyses were used to further describe the data sets and to seek underlying trends and driving factors. The Mann-Whitney and t-tests performed indicate whether the upper riparian and lower riparian sites are statistically the same based on individual measured variables. Multivariate methods were used to attempt to explain what the differences are considering all factors together, and to describe how different the zones are overall, rather than in terms of single factors. The zones may appear to be similar based on single factor comparisons, but the aggregate differences may reveal something more useful.

Vegetation cover similarity between the upper and lower riparian zones was performed using PRIMER software. Two primary data categories were established: upper riparian dominant species and lower riparian dominant species. A similarity matrix was produced, using a Euclidian measure. This matrix described an index of similarity between each site and each other site, based on the percent cover of all dominant species present at each site. This matrix was used to create a MultiDimensional Scaling (MDS) plot, which is a map of the statistical distance between sites based on data interrelationships in an ordination using non-metric scaling (Clarke 1993). The MDS plot allowed a visual analysis of the similarity of sites to each other, based on the percent cover of all dominant species present at each site. Finally, oneway Analysis of Similarity (ANOSIM) was performed on the similarity matrix. ANOSIM tested the null hypothesis that there is no difference between the zones. The test ranked all differences between pairs of data points, categorized the ranks as between groups or within groups, and then calculated a mean rank for each group. The 
mean rank within groups was subtracted from the mean rank between groups, and this value was divided by a correction factor for the number of combinations used. The result of this test was the $R$ statistic. The statistical significance of $R$ was determined by permuting the grouping vector, in this case a maximum of 999 times. This established the distribution of the test statistic $R$. If the $\mathrm{P}$ value of $R$ was $\leq 0.05$ then the null hypothesis was rejected, and the two groups were considered statistically dissimilar based on the aggregation of differences in the data points (Clarke 1993). The same set of analyses was performed, using identical techniques, on two environmental data categories: upper riparian environmental variables and lower riparian environmental variables. These analyses described and compared sites based on the values of all environmental data for each site.

Variation within the dominant species percent quadrat cover and environmental factor datasets was addressed with Principle Components Analysis (PCA), using PRIMER software. Six data sets were established: upper riparian dominant species $(n=30)$, upper riparian environmental factors $(n=30)$, lower riparian dominant species $(n=30)$, lower riparian environmental factors $(n=30)$, total riparian zone dominant species $(n=60)$, and total riparian zone environmental factors $(n=60)$. Further refinement on environmental datasets included breaking each into two additional datasets: one with the texture components gravel, sand, silt, and clay; one with the texture components gravel, four different sand size categories, silt, and clay. PCA attempted to reduce the entire dataset into a smaller number of synthetic variables ("components," in this case a maximum of five) that represent multiple 
original dataset variables. This was accomplished by analyzing the covariation and finding the strongest linear correlation structure among multiple variables. The results of the PCA included the five principle components with associated eigenvalues, which described the data variance explained by each component. Each component also had an associated eigenvector for each variable. Eigenvectors indicate the contribution of each variable to the component (McCune and Grace 2002). The PCA allowed a more thorough description and understanding of the aggregate sources of variation in the dominant species and environmental variable datasets. 


\section{RESULTS}

\section{Vegetation Data}

Across all 60 quadrats included in the study, 34 total species were identified (Table 3). 14 species account for at least $1 \%$ of total vegetation cover each, and combined account for $93.81 \%$ of total riparian cover. Xanthium strumarium has the greatest cover (20.54\%), followed by Phalaris arundinacea (15.59\%), and Equisetum arvense $(10.82 \%)$. Other dominant species (those that appeared in at least three quadrats and account for at least $1 \%$ of the total cover), include Scirpus americanus, Carex aquatilis, Eleocharis palustris, Solidago occidentalis, Glycyrrhiza lepidota, Salix exigua, Polygonum lapathifolium, Leersia oryzoides, Euphorbia supina (Chamaesyce maculate), Mollugo verticillata, and Oxalis corniculata. Table 4 shows percent of total cover for all species encountered in the entire study area.

Facultative vegetation (FAC) comprise $39.10 \%$ of the total riparian vegetation studied, followed by wetland obligate species (OBL) at $31.68 \%$, facultative wetland species (FACW) at $25.63 \%$, facultative upland species (FACU) at $2.26 \%$, and upland species (UPL) at $1.12 \%$ (Figure 8 ). A single occurrence of Rhus radicans (Toxicodendron rydbergii), which has no designated wetland status (NI), accounts for $0.22 \%$ of total riparian cover. There are ten total FAC species, nine OBL species, seven FACW species, six FACU species, one UPL species, and one species without wetland status encountered in the entire riparian zone. 
Table 3. Species List

\begin{tabular}{|c|c|c|c|}
\hline Species name & Wetland Indicator Status & Upper & Lower \\
\hline Achillea millefolium & FACU & $\mathrm{x}$ & \\
\hline Agropyron repens & FACU & $\mathrm{x}$ & $\mathrm{x}$ \\
\hline Agrostis Alba & FAC & $x$ & $\mathrm{X}$ \\
\hline Alopecurus aequalis & $\mathrm{OBL}$ & & $x$ \\
\hline Carex aquatilis & $\mathrm{OBL}$ & $\mathrm{x}$ & $x$ \\
\hline Cyperus aristatus & OBL & & $\mathrm{X}$ \\
\hline Echinochloa crus-galli, & FACW & & $\mathrm{x}$ \\
\hline Eleocharis palustris & $\mathrm{OBL}$ & $\mathrm{X}$ & $x$ \\
\hline Equisetum arvense & FAC & $\mathrm{x}$ & $x$ \\
\hline Euphorbia supina & UPL & $\mathrm{X}$ & $x$ \\
\hline Glyceria striata & $\mathrm{OBL}$ & & $x$ \\
\hline Glycyrrhiza lepidota & FAC & $\mathrm{X}$ & $x$ \\
\hline Leersia oryzoides & $\mathrm{OBL}$ & $\mathrm{X}$ & $x$ \\
\hline Lycopus americanus & $\mathrm{OBL}$ & $x$ & \\
\hline Mentha arvensis & FACW & $x$ & $\mathrm{x}$ \\
\hline Mollugo verticillata & FAC & $\mathrm{X}$ & $x$ \\
\hline Muhlenbergia richardsonis & FAC & & $x$ \\
\hline Oxalis corniculata & FACU & $\mathrm{X}$ & $x$ \\
\hline Pascopyrum smithii & FACU & $x$ & \\
\hline Phalaris arundinacea & FACW & $\mathrm{X}$ & $\mathrm{X}$ \\
\hline Plantago lanceolata & FACU & $x$ & \\
\hline Plantago major & FAC & $x$ & $\mathrm{X}$ \\
\hline Polygonum lapathifolium & FACW & $\mathrm{X}$ & $\mathrm{x}$ \\
\hline Rumex crispus & FAC & $\mathrm{X}$ & \\
\hline Rumex salicifolius & FAC & & $x$ \\
\hline Salix exigua & $\mathrm{OBL}$ & $x$ & $x$ \\
\hline Salix lasiandra & FACW & & $\mathrm{x}$ \\
\hline Salix scouleriana & FAC & & $x$ \\
\hline Scirpus americanus & $\mathrm{OBL}$ & $\mathrm{x}$ & $\mathrm{x}$ \\
\hline Setaria viridis & FACU & & $x$ \\
\hline Solidago occidentalis & FACW & $\mathrm{X}$ & $x$ \\
\hline Rhus radicans & NI & $x$ & \\
\hline Trifolium wormskjoldii & FACW & $x$ & \\
\hline Xanthium strumarium & FAC & $x$ & $x$ \\
\hline \multicolumn{2}{|l|}{ Total species in each zone } & 25 & 27 \\
\hline \multicolumn{2}{|l|}{ Total species in study } & \multicolumn{2}{|c|}{34} \\
\hline
\end{tabular}


Table 4. Percent of Total Vegetation Cover by Species

\begin{tabular}{|l|l|r|r|r|}
\hline & \multirow{2}{*}{$\begin{array}{l}\text { Wetland } \\
\text { Indicator } \\
\text { Species name }\end{array}$} & $\begin{array}{l}\text { Percent of } \\
\text { Total Study } \\
\text { Area }\end{array}$ & $\begin{array}{l}\text { Percent of } \\
\text { Upper } \\
\text { Riparian }\end{array}$ & $\begin{array}{l}\text { Percent of } \\
\text { Lower } \\
\text { Riparian }\end{array}$ \\
\hline Achillea millefolium & FACU & 0.01 & 0.03 & 0.00 \\
\hline Agropyron repens & FACU & 0.87 & 1.64 & 0.14 \\
\hline Agrostis Alba & FAC & 0.15 & 0.15 & 0.14 \\
\hline Alopecurus aequalis & OBL & 0.22 & 0.00 & 0.42 \\
\hline Carex aquatilis & OBL & 7.69 & 3.88 & 11.28 \\
\hline Cyperus aristatus & OBL & 0.87 & 0.00 & 1.69 \\
\hline Echinochloa crus-galli, & FACW & 0.22 & 0.00 & 0.42 \\
\hline Eleocharis palustris & OBL & 6.45 & 6.12 & 6.77 \\
\hline Equisetum arvense & FAC & 10.82 & 7.50 & 13.96 \\
\hline Euphorbia supina & UPL & 1.12 & 0.60 & 1.61 \\
\hline Glyceria striata & OBL & 0.51 & 0.00 & 0.99 \\
\hline Glycyrrhiza lepidota & FAC & 5.29 & 4.03 & 6.48 \\
\hline Leersia oryzoides & OBL & 2.83 & 1.19 & 4.37 \\
\hline Lycopus americanus & OBL & 0.44 & 0.90 & 0.00 \\
\hline Mentha arvensis & FACW & 0.87 & 0.15 & 1.55 \\
\hline Mollugo verticillata & FAC & 1.06 & 0.54 & 1.55 \\
\hline Muhlenbergia richardsonis & FAC & 0.07 & 0.00 & 0.14 \\
\hline Oxalis corniculata & FACU & 1.02 & 0.15 & 1.83 \\
\hline Pascopyrum smithii & FACU & 0.15 & 0.30 & 0.00 \\
\hline Phalaris arundinacea & FACW & 15.59 & 27.78 & 4.09 \\
\hline Plantago lanceolata & FACU & 0.15 & 0.30 & 0.00 \\
\hline Plantago major & FAC & 0.58 & 0.75 & 0.42 \\
\hline Polygonum lapathifolium & FACW & 2.90 & 2.69 & 3.10 \\
\hline Rumex crispus & FAC & 0.51 & 1.05 & 0.00 \\
\hline Rumex salicifolius & FAC & 0.01 & 0.00 & 0.03 \\
\hline Salix exigua & OBL & 4.90 & 3.32 & 6.40 \\
\hline Salix lasiandra & FACW & 0.15 & 0.00 & 0.28 \\
\hline Salix scouleriana & FAC & 0.07 & 0.00 & 0.14 \\
\hline Scirpus americanus & OBL & 7.77 & 4.21 & 11.14 \\
\hline Setaria viridis & FACU & 0.07 & 0.00 & 0.14 \\
\hline Solidago occidentalis & FACW & 5.83 & 6.75 & 4.96 \\
\hline Rhus radicans & NI & 0.22 & 0.45 & 0.00 \\
\hline Trifolium wormskjoldii & FACW & 0.15 & 0.00 \\
\hline Xanthium strumarium & FAC & 25.39 & 15.96 \\
\hline
\end{tabular}


Figure 8. Percent Total Cover by Wettand Indicator Status

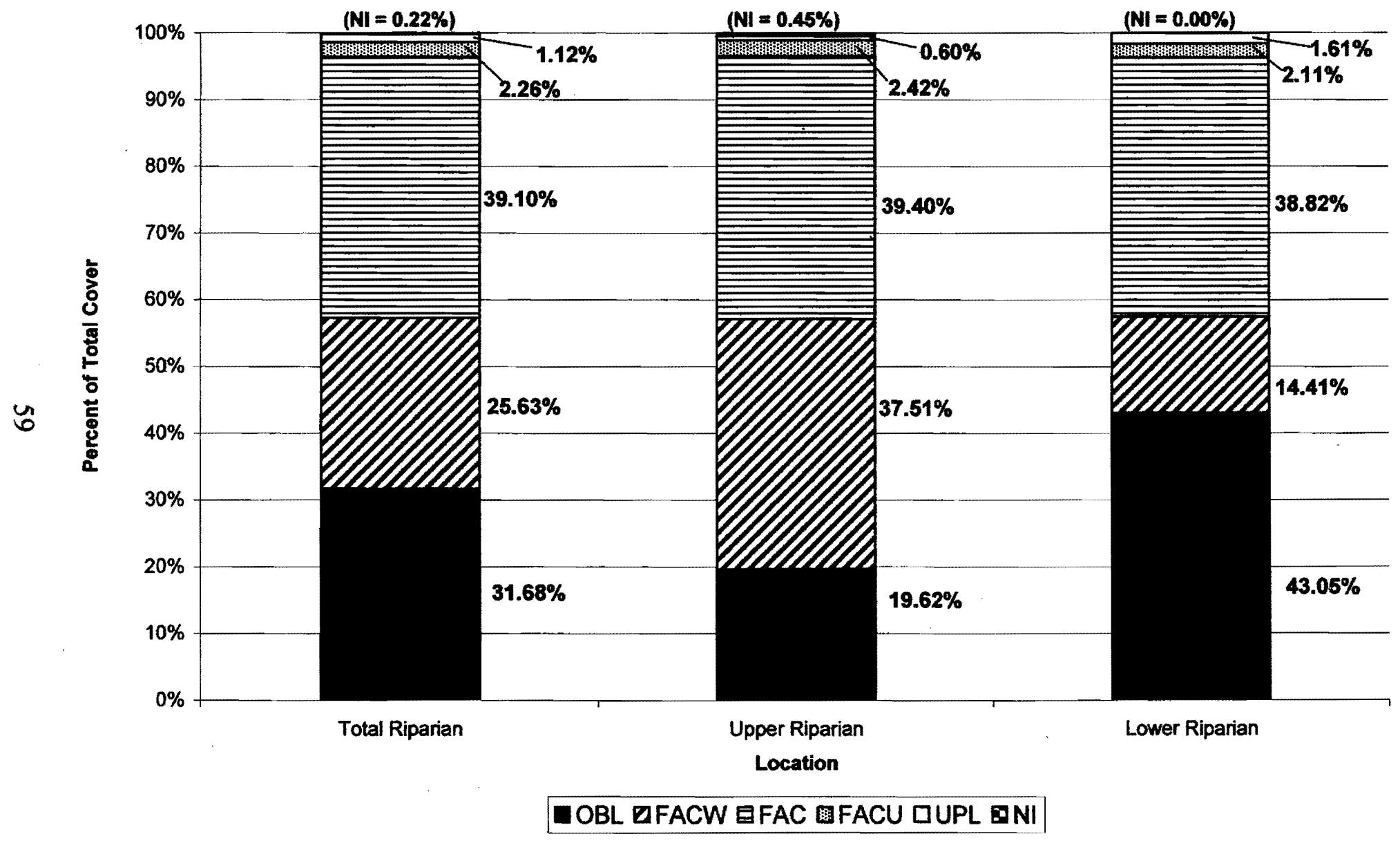




\section{Upper Riparian Zone}

The upper riparian zone study sites include 25 total species. Seven of these species do not occur in the lower riparian zone: Achillea millefolium, Lycopus americanus, Pascopyrum smithii, Plantago lanceolata, Rhus radicans, Rumex crispus, and Trifolium wormskjoldii. Each of these species accounts for less than $1 \%$ of the total cover in the upper riparian zone, with the exception of Rumex crispus, at $1.05 \%$. 13 dominant species, accounting for $95.55 \%$ of upper riparian cover, are found in the upper riparian zone. Phalaris arundinacea and Xanthium strumarium account for $27.78 \%$ and $25.39 \%$, respectively, of the total upper riparian vegetation cover. Equisetum arvense, Solidago occidentalis, Eleocharis palustris, Scirpus americanus, Glycyrrhiza lepidota, Carex aquatilis, Salix exigua, Polygonum lapathifolium, Agropyron repens, Leersia oryzoides, and Rumex crispus are the other dominant species, each of which account for less than $10 \%$ of the total upper riparian cover. Table 3 shows the percent of total riparian cover for each species. Mean percent of upper riparian quadrat cover by each dominant species is shown in Table 5.

FAC species account for $39.40 \%$, FACW species for $37.51 \%$, OBL species for $19.62 \%$, FACU species for $2.42 \%$, and UPL species for $0.60 \%$ of total vegetation cover in the upper riparian zone (Figure 8). A single occurrence of Rhus radicans (Toxicodendron rydbergii), accounts for $0.45 \%$ of upper riparian cover. There are seven total FAC, six OBL, five FACW, five FACU, one UPL and one NI upper riparian species. Mean upper riparian quadrat cover by OBL species is $19.6 \%$, by 
FACW species is $44.2 \%$, by FAC species is $46.8 \%$, by FACU species is $0.87 \%$, and by UPL species is $0.33 \%$ (Table 6 ).

Table 5. Dominant Species Percent of Quadrat Cover - Basic Descriptive Statistics

\begin{tabular}{|l|l|l|l|l|}
\hline \multirow{2}{*}{ Species } & \multicolumn{2}{l|}{ Mean\% Quadrat Cover } & \multicolumn{2}{l|}{ Standard Deviation } \\
\cline { 2 - 5 } & Upper & Lower & Upper & Lower \\
\hline Agropyron repens & 1.83 & 0.17 & 4.25 & 0.91 \\
\hline Carex aquatilis & 4.33 & 13.33 & 13.50 & 21.23 \\
\hline Cyperus aristatus & 0.00 & 2.00 & 0.00 & 5.34 \\
\hline Eleocharis palustris & 6.83 & 8.00 & 12.28 & 12.91 \\
\hline Equisetum arvense & 8.37 & 16.50 & 14.33 & 22.52 \\
\hline Euphorbia supina & 0.67 & 1.90 & 2.17 & 2.75 \\
\hline Glycyrrhiza lepidota & 4.50 & 7.67 & 8.24 & 17.89 \\
\hline Leersia oryzoides & 1.33 & 5.17 & 5.24 & 9.33 \\
\hline Mentha arvensis & 0.17 & 1.83 & 0.91 & 4.25 \\
\hline Mollugo verticillata & 0.60 & 1.83 & 1.52 & 4.04 \\
\hline Oxalis corniculata & 0.17 & 2.17 & 0.91 & 5.52 \\
\hline Phalaris arundinacea & 31.00 & 4.83 & 28.75 & 6.63 \\
\hline Polygonum lapathifolium & 3.00 & 3.67 & 6.77 & 8.99 \\
\hline Rumex crispus & 1.17 & 0.00 & 3.87 & 0.00 \\
\hline Salix exigua & 3.70 & 7.57 & 4.32 & 8.11 \\
\hline Scirpus americanus & 4.70 & 13.17 & 13.57 & 17.09 \\
\hline Solidago occidentalis & 7.53 & 5.87 & 8.76 & 7.18 \\
\hline Xanthium strumarium & 28.33 & 18.87 & 21.19 & 18.75 \\
\hline
\end{tabular}


Table 6. Descriptive Statistics for Percent Quadrat Cover by Wetland Indicator Status

\begin{tabular}{|l|l|l|l|l|}
\hline \multirow{2}{*}{ Wetland Indicator Status } & \multicolumn{3}{|l|}{ Mean \% Quadrat Cover } & \multicolumn{2}{l|}{ Standard Deviation } \\
\cline { 2 - 5 } & Upper & Lower & Upper & Lower \\
\hline OBL & 19.60 & 50.90 & 20.40 & 17.10 \\
\hline FACW & 44.20 & 17.90 & 29.80 & 11.50 \\
\hline FAC & 46.80 & 44.30 & 22.50 & 24.20 \\
\hline FACU & 0.87 & 2.67 & 2.30 & 5.50 \\
\hline UPL & 0.33 & 1.90 & 1.30 & 2.70 \\
\hline
\end{tabular}

\section{Lower Riparian Zone}

Lower riparian species total 27. Nine of these do not occur in the upper riparian zone: Alopecurus aequalis, Cyperus aristatus, Echinochloa crus-galli, Glyceria striata, Muhlenbergia richardsonis, Rumex salicifolius, Salix lasiandra, Salix scouleriana, and Setaria viridis. Each of these species, with the exception of Cyperus aristatus, accounts for less than $1 \%$ of total lower riparian cover. 16 dominant species account for $96.73 \%$ of the total lower riparian vegetation cover. The four most dominant species include Xanthium strumarium at $15.96 \%$, Equisetum arvense at $13.96 \%$, Carex aquatilis at $11.28 \%$, and Scirpus americanus at $11.14 \%$ of total lower riparian cover. Eleocharis palustris, Glycyrrhiza lepidota, Salix exigua, Solidago (Euthamia) occidentalis, Leersia oryzoides, Polygonum lapathifolium, Oxalis corniculata, Cyperus aristatus, Euphorbia supina (Chamaesyce maculate), Mentha arvensis, and Mollugo verticillata are the other dominant species each of which accounts for less than $10 \%$ of total lower riparian cover. Table 4 shows the percent of all lower riparian cover for each species. 
OBL species account for $43.05 \%$, FAC species for $38.82 \%$, FACW species for $14.41 \%$, FACU species for $2.11 \%$, and UPL species for $1.61 \%$ of total lower riparian vegetation cover (Figure 8). Nine FAC, eight OBL, six FACW, three FACU, and one

UPL species are found in the lower riparian zone. The mean percent of lower riparian quadrat cover is $50.9 \%$ for OBL species, $17.9 \%$ for FACW species, $44.3 \%$ for FAC species, $2.27 \%$ for FACU species, and $1.9 \%$ for UPL species (Table 6).

\section{Comparison of Upper and Lower Zones}

The two zones display several notable differences in terms of vegetation (Table 5, Table 7, Table 8, Figure 9). The lower riparian zone contains three more dominant species than the upper riparian zone. In the lower riparian zone there are no species that individually accounted for a notably high percentage of total cover. However, in the upper zone, there are several species that accounted for high percentages of total cover, while the remaining dominant species each account for a relatively small percentage of total cover (Figure 9). Two species $-P$. arundinacea and $X$. strumarium combined account for $53.17 \%$ of total vegetation cover, and an average of $59.33 \%$ of quadrat cover in the upper riparian zone (Table 5 and Table 7). These same species account for only $20.05 \%$ of total cover and an average of $23.70 \%$ of quadrat cover in the lower riparian zone. The vegetation cover is distributed more evenly across more species in the lower zone than the upper zone. The four species with greatest cover in the lower zone $-X$. strumarium, E. arvense, $C$. aquatilis, and $S$. americanus account for $52.33 \%$ of total lower riparian cover, and an average of $61.86 \%$ of lower riparian 
quadrat cover. Table 8 shows the ranking of each species in terms of its percent of total cover in each zone. $X$. strumarium and $E$. arvense ranked highly in both the upper and lower riparian zones, although $E$. arvense is responsible for roughly twice the percentage of vegetation cover in the lower zone than in the upper zone. E. palustris ranks similarly across both zones, and is responsible for similar percentages of total cover. The remainder of high ranking dominant species cover is not particularly similar between zones. The upper riparian zone is dominated by FAC and FACW plant species, while the lower zone is dominated by OBL and FAC species (Figure 8).

Table 7. Dominant Species Percent of Total Vegetation Cover - by Zone

\begin{tabular}{|l|l|l|l|}
\hline Species name & Total Study Area & Upper Riparian & Lower Riparian \\
\hline Agropyron repens & \multicolumn{3}{|l|}{$1.64 \%$} \\
\hline Carex aquatilis & $7.69 \%$ & $3.88 \%$ & $11.28 \%$ \\
\hline Cyperus aristatus & \multicolumn{2}{|l|}{} & $1.69 \%$ \\
\hline Eleocharis palustris & $6.45 \%$ & $6.12 \%$ & $6.77 \%$ \\
\hline Equisetum arvense & $10.82 \%$ & $7.50 \%$ & $13.96 \%$ \\
\hline Euphorbia supina & $1.12 \%$ & & $1.61 \%$ \\
\hline Glycyrrhiza lepidota & $5.29 \%$ & $4.03 \%$ & $6.48 \%$ \\
\hline Leersia oryzoides & $2.83 \%$ & $1.19 \%$ & $4.37 \%$ \\
\hline Mentha arvensis & & & $1.55 \%$ \\
\hline Mollugo verticillata & $1.06 \%$ & & $1.55 \%$ \\
\hline Oxalis corniculata & $1.02 \%$ & $27.78 \%$ & $1.83 \%$ \\
\hline Phalaris arundinacea & $15.59 \%$ & $2.69 \%$ & $4.09 \%$ \\
\hline Polygonum lapathifolium & $2.90 \%$ & $1.05 \%$ & $3.10 \%$ \\
\hline Rumex crispus & & $3.32 \%$ & \\
\hline Salix exigua & $4.90 \%$ & $4.21 \%$ & $6.40 \%$ \\
\hline Scirpus americanus & $7.77 \%$ & $6.75 \%$ & $11.14 \%$ \\
\hline Solidago occidentalis & $5.83 \%$ & $25.39 \%$ & $4.96 \%$ \\
\hline Xanthium strumarium & $20.54 \%$ & & $15.96 \%$ \\
\hline
\end{tabular}


Table 8. Vegetation Cover Ranks - Dominant Species by Zone

\begin{tabular}{|l|l|l|l|}
\hline Species name & Total Study Area & Upper Riparian & Lower Riparian \\
\hline Xanthium strumarium & 1 & 2 & 1 \\
\hline Phalaris arundinacea & 2 & 1 & 10 \\
\hline Equisetum arvense & 3 & 3 & 2 \\
\hline Scirpus americanus & 4 & 6 & 4 \\
\hline Carex aquatilis & 5 & 8 & 3 \\
\hline Eleocharis palustris & 6 & 5 & 5 \\
\hline Solidago occidentalis & 7 & 4 & 8 \\
\hline Glycyrnhiza lepidota & 8 & 7 & 6 \\
\hline Salix exigua & 9 & 9 & 7 \\
\hline Polygonum lapathifolium & 10 & 10 & 11 \\
\hline Leersia oryzoides & 11 & 12 & 9 \\
\hline Euphorbia supina & 12 & & 14 \\
\hline Mollugo verticillata & 13 & & 15 \\
\hline Oxalis corniculata & 14 & & 12 \\
\hline Cyperus aristatus & & & 13 \\
\hline Mentha arvensis & & & 16 \\
\hline Agropyron repens & & 11 & \\
\hline Rumex crispus & & 13 & \\
\hline Shas & & & \\
\hline
\end{tabular}

Shaded cells indicate that the species is not one of the dominant species for the zone represented by that column. 
Figure 9. Dominant Species Cover by Zone

Dominant Species Cover by Zone

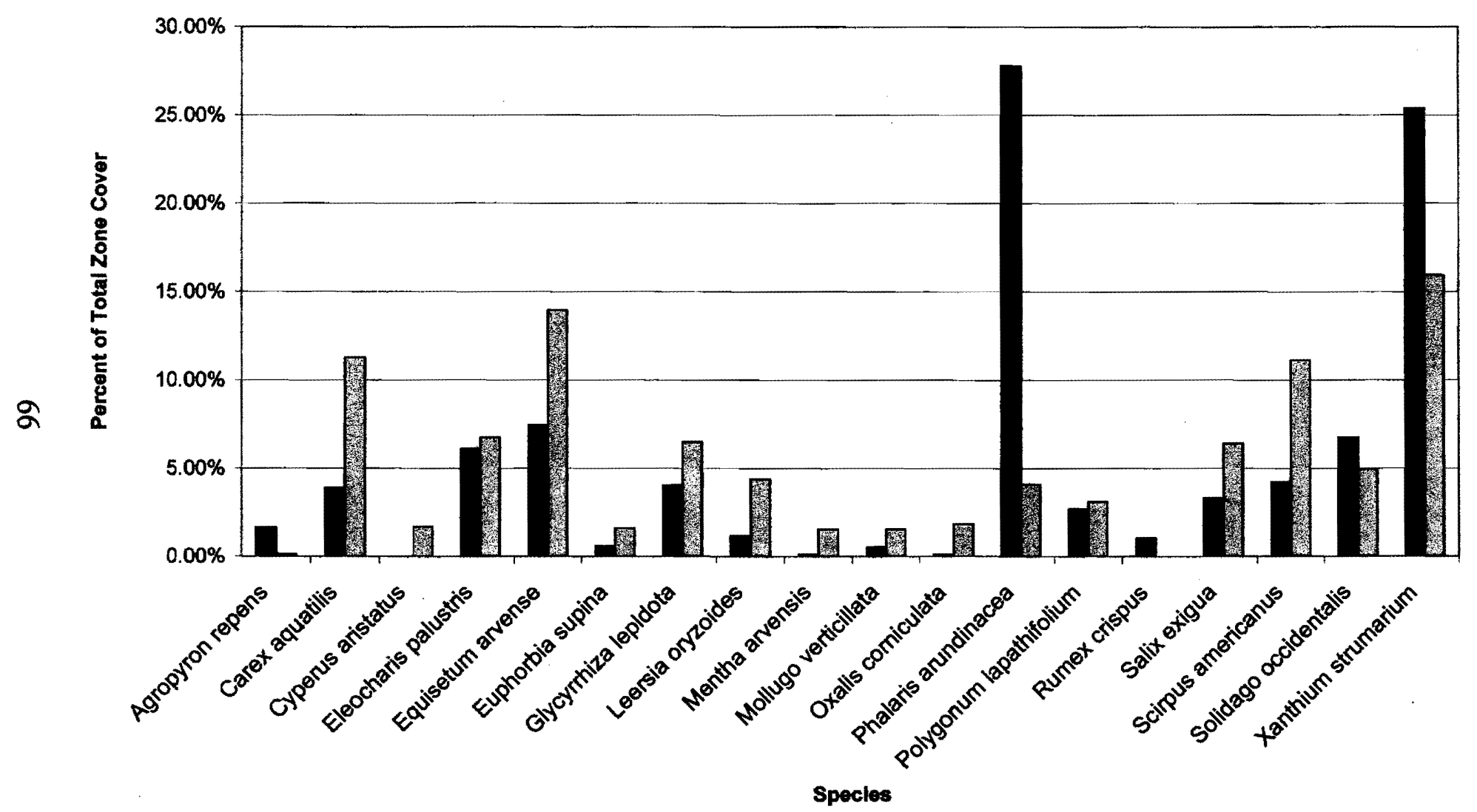

Upper Riparian 1 Lower Riparian 
Table 9 displays the results of the Mann-Whitney tests performed on each dominant species to compare between the upper and lower riparian zones as a test of the null hypothesis that the two zones would display no difference in terms of vegetation. Statistically significant differences are found between the two zones for percent quadrat cover for Carex aquatilis, Cyperus aristatus, Euphorbia supina (Chamaesyce maculate), Leersia oryzoides, Mentha arvensis, Phalaris arundinacea, Rumex crispus, and Scirpus americanus. Of the species with significant differences, only $P$. arundinacea and $R$. crispus have greater average percent of quadrat cover in the upper zone. Combined, all species with significantly different quadrat cover percentages between zones account for $38.86 \%$ and $34.03 \%$ of the total vegetation cover, and for an average of $43.36 \%$ and $40.23 \%$ of quadrat cover, in the upper and lower zones, respectively (Table 10). Carex aquatilis, Phalaris arundinacea, and Scirpus americanus show the most variation between the upper and lower riparian zones. Each also accounts for at least $10 \%$ of total vegetation cover in one zone and substantially less than $10 \%$ in the other. Table 11 displays the t-test results for the percentage of quadrat cover by wetland indicator status, compared between the upper and lower zones. A comparison was not possible for UPL and FACU groups, as there were not enough data points to conduct a valid test. The two zones are statistically the same in terms of FAC species quadrat cover. However, in terms of both OBL and FACW species, the zones are statistically different. 
Table 9. Dominant Species Percent Quadrat Cover, Mann-Whitney Test Results

\begin{tabular}{|l|l|l|l|}
\hline Species & U & P & Reject Ho \\
\hline Agropyron repens & 977.5 & 0.0781 & No \\
\hline Eleocharis palustris & & & \\
\hline Equisetum arvense & 862 & 0.3744 & No \\
\hline Glycyrrhiza lepidota & 815.5 & 0.1262 & No \\
\hline & & & \\
\hline Mollugo verticillata & 944.5 & 0.5894 & No \\
\hline Oxalis corniculata & & & \\
\hline Polygonum lapathifolium & 871.5 & 0.3891 & No \\
\hline Salix exigua & 853 & 0.0807 & No \\
\hline Solidago occidentalis & & & \\
\hline Xanthium strumarium & 902 & 0.7975 & No \\
\hline
\end{tabular}

Shaded cells contain species for which the $\mathrm{H}_{0}$ was rejected.

Table 10. Summary of Mean Quadrat and Percent of Total Cover by Species with Significantly different Mean Quadrat Cover (Reject Mann-Whitney $\mathbf{H}_{0}$ )

\begin{tabular}{|l|l|l|l|l|}
\hline \multirow{2}{*}{ Dominant Species } & \multicolumn{2}{|c|}{$\begin{array}{c}\text { Mean Percent of } \\
\text { Quadrat Cover }\end{array}$} & \multicolumn{2}{c|}{$\begin{array}{c}\text { Percent of Total } \\
\text { Vegetation Cover }\end{array}$} \\
\cline { 2 - 5 } & Upper Riparian & $\begin{array}{l}\text { Lower } \\
\text { Riparian }\end{array}$ & Upper Riparian & $\begin{array}{l}\text { Lower } \\
\text { Riparian }\end{array}$ \\
\hline Carex aquatilis & $4.33 \%$ & $13.33 \%$ & $3.88 \%$ & $11.28 \%$ \\
\hline Euphorbia supina & $0.67 \%$ & $1.90 \%$ & $0.60 \%$ & $1.61 \%$ \\
\hline Leersia oryzoides & $1.33 \%$ & $5.17 \%$ & $1.19 \%$ & $4.37 \%$ \\
\hline Mentha arvensis & $0.17 \%$ & $1.83 \%$ & $0.15 \%$ & $1.55 \%$ \\
\hline Phalaris arundinacea & $31.00 \%$ & $4.83 \%$ & $27.78 \%$ & $4.09 \%$ \\
\hline Rumex crispus & $1.17 \%$ & $0.00 \%$ & $1.05 \%$ & $0.00 \%$ \\
\hline Scirpus americanus & $4.70 \%$ & $13.17 \%$ & $4.21 \%$ & $11.14 \%$ \\
\hline Total for zone: & $43.36 \%$ & $40.23 \%$ & $38.86 \%$ & $34.03 \%$ \\
\hline
\end{tabular}


Table 11. T-Test Results for Percent of Quadrat Cover by Wetland Indicator Status

\begin{tabular}{|c|c|c|c|}
\hline \multirow[b]{2}{*}{ Wetland Indicator Status } & \multicolumn{3}{|c|}{ t-Test results } \\
\hline & T-val & P-val & Reject Ho \\
\hline FAC & 0.42 & 0.676 & No \\
\hline FACU & \multicolumn{3}{|c|}{ Too few data points } \\
\hline UPL & \multicolumn{3}{|c|}{ Too few data points } \\
\hline
\end{tabular}

Shaded cells indicate wetland indicator status groups for which the $\mathrm{H}_{0}$ was rejected

A multi-dimensional scaling (MDS) plot is shown in Figure 10. The MDS plot does not provide a quantifiable measure of similarity between the upper and lower zone, but visually indicates the similarity of individual sites to other individual sites, based on all data for each site. Some clustering of sites by zone is visually evident. These loose clusters overlap to some extent, with several sites in the upper zone and lower zone located further from the area of overlap. This indicates that many of the sites are similar in terms of vegetation data, regardless of zone, but that there are certain sites in the upper zone that have a high degree of dissimilarity to certain sites in the lower zone. The MDS plot was useful for a qualitative visual description of sites relative to each other, but was not useful for hypothesis testing, so the ANOSIM was used. The ANOSIM analysis considered variation in percent of quadrat cover of all the dominant species in both riparian zones. The resulting $R$ statistic for species between zones is 0.16 , with a P value of 0.001 . Therefore, the $R$ null hypothesis, that the two zones are statistically the same in terms of vegetation, was rejected. While individual species comparisons for quadrat cover vary between statistically the same and statistically different between the two zones, the ANOSIM analysis demonstrates that 
the upper and lower riparian zones are distinct from each other based on the aggregated differences for all species data within them.

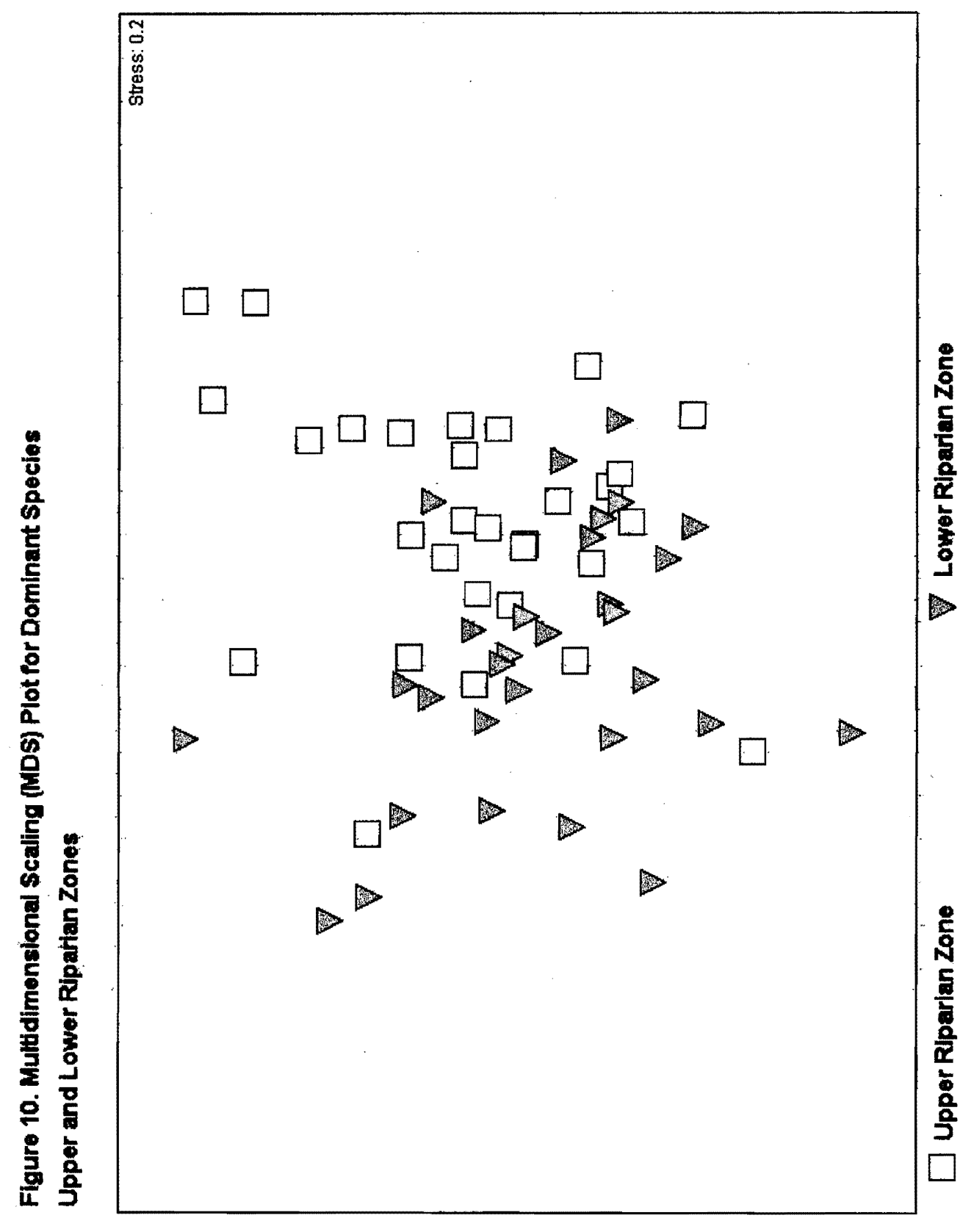


The results of principle components analyses conducted for species data in the total, upper, and lower riparian zones are presented in Table 12 through Table 14.

Table 12. Principle Components Analysis for Total Riparian Dominant Species

\begin{tabular}{|c|c|c|c|c|c|}
\hline PC & Eigenvalues & $\%$ Variation & $\begin{array}{l}\text { Cumulative } \\
\text { \%Variation }\end{array}$ & & \\
\hline 1 & 2.62 & 13.1 & 13.1 & & \\
\hline 2 & 2.35 & 11.8 & 24.8 & & \\
\hline 3 & 2.06 & 10.3 & 35.1 & & \\
\hline 4 & 1.71 & 8.5 & 43.7 & & \\
\hline 5 & 1.56 & 7.8 & 51.5 & & \\
\hline Species & PC1 & PC2 & PC3 & PC4 & PC5 \\
\hline $\begin{array}{l}\text { Agropyron } \\
\text { repens }\end{array}$ & 0.293 & -0.486 & -0.087 & -0.030 & -0.145 \\
\hline Carex aquatilis & -0.066 & -0.020 & 0.009 & -0.191 & 0.404 \\
\hline $\begin{array}{l}\text { Cyperus } \\
\text { aristatus }\end{array}$ & 0.304 & 0.240 & 0.355 & -0.015 & -0.119 \\
\hline $\begin{array}{l}\text { Eleocharis } \\
\text { palustris }\end{array}$ & 0.024 & -0.012 & -0.101 & 0.062 & 0.143 \\
\hline $\begin{array}{l}\text { Equisetum } \\
\text { arvense }\end{array}$ & -0.287 & -0.210 & 0.253 & -0.106 & 0.050 \\
\hline $\begin{array}{l}\text { Euphorbia } \\
\text { supina }\end{array}$ & 0.362 & 0.039 & 0.401 & 0.072 & -0.101 \\
\hline $\begin{array}{l}\text { Glycyrrhiza } \\
\text { lepidota }\end{array}$ & -0.297 & 0.004 & 0.104 & -0.242 & -0.013 \\
\hline $\begin{array}{l}\text { Leersia } \\
\text { oryzoides }\end{array}$ & -0.134 & 0.259 & -0.093 & 0.037 & 0.138 \\
\hline Mentha arvensis & -0.157 & -0.050 & 0.087 & 0.627 & -0.075 \\
\hline $\begin{array}{l}\text { Mollugo } \\
\text { verticillata }\end{array}$ & 0.333 & 0.121 & 0.425 & -0.022 & -0.089 \\
\hline $\begin{array}{l}\text { Oxalis } \\
\text { corniculata }\end{array}$ & 0.034 & 0.029 & -0.017 & 0.057 & 0.546 \\
\hline $\begin{array}{l}\text { Phalaris } \\
\text { arundinacea }\end{array}$ & -0.004 & 0.093 & -0.291 & -0.212 & -0.419 \\
\hline $\begin{array}{l}\text { Polygonum } \\
\text { lapathifolium }\end{array}$ & 0.017 & 0.237 & -0.058 & -0.089 & -0.274 \\
\hline Rumex crispus & 0.258 & -0.470 & -0.065 & -0.051 & -0.106 \\
\hline Salix exigua & -0.248 & -0.081 & 0.439 & -0.246 & 0.058 \\
\hline $\begin{array}{l}\text { Scirpus } \\
\text { americanus }\end{array}$ & -0.212 & 0.013 & 0.063 & 0.588 & -0.128 \\
\hline $\begin{array}{l}\text { Solidago } \\
\text { occidentalis }\end{array}$ & 0.151 & -0.478 & -0.011 & 0.075 & 0.103 \\
\hline $\begin{array}{l}\text { Xanthium } \\
\text { strumarium }\end{array}$ & 0.399 & 0.198 & -0.321 & 0.075 & 0.211 \\
\hline
\end{tabular}


Table 13. Principle Components Analysis for Upper Riparian Dominant Species

\begin{tabular}{|c|c|c|c|c|c|}
\hline PC & Eigenvalues & $\%$ Variation & $\begin{array}{l}\text { Cumulative } \\
\text { \%Variation }\end{array}$ & & \\
\hline 1 & 3.47 & 20.4 & 20.4 & & \\
\hline 2 & 2.77 & 16.3 & 36.7 & & \\
\hline 3 & 1.89 & 11.1 & 47.8 & & \\
\hline 4 & 1.43 & 8.4 & 56.2 & & \\
\hline 5 & 1.28 & 7.5 & 63.8 & & \\
\hline Species & PC1 & PC2 & PC3 & PC4 & PC5 \\
\hline $\begin{array}{l}\text { Agropyron } \\
\text { repens }\end{array}$ & 0.195 & -0.516 & 0.003 & 0.094 & -0.149 \\
\hline Carex aquatilis & -0.081 & -0.182 & -0.108 & -0.205 & 0.611 \\
\hline $\begin{array}{l}\text { Eleocharis } \\
\text { palustris }\end{array}$ & 0.042 & 0.112 & 0.318 & 0.400 & -0.046 \\
\hline $\begin{array}{l}\text { Equisetum } \\
\text { arvense }\end{array}$ & -0.318 & -0.176 & 0.026 & -0.126 & -0.048 \\
\hline $\begin{array}{l}\text { Euphorbia } \\
\text { supina }\end{array}$ & 0.178 & -0.134 & 0.200 & 0.202 & -0.180 \\
\hline $\begin{array}{l}\text { Glycyrrhiza } \\
\text { lepidota }\end{array}$ & -0.437 & -0.087 & -0.004 & 0.253 & 0.132 \\
\hline Mentha arvensis & -0.298 & -0.034 & 0.027 & 0.416 & 0.046 \\
\hline $\begin{array}{l}\text { Mollugo } \\
\text { verticillata }\end{array}$ & 0.212 & -0.131 & 0.375 & 0.247 & 0.294 \\
\hline $\begin{array}{l}\text { Oxalis } \\
\text { corniculata }\end{array}$ & -0.023 & 0.032 & -0.137 & -0.208 & 0.539 \\
\hline $\begin{array}{l}\text { Phalaris } \\
\text { arundinacea }\end{array}$ & 0.082 & 0.236 & 0.463 & -0.210 & -0.105 \\
\hline $\begin{array}{l}\text { Polygonum } \\
\text { lapathifolium }\end{array}$ & 0.102 & 0.193 & 0.437 & 0.224 & 0.227 \\
\hline Rumex crispus & 0.172 & -0.502 & 0.060 & 0.094 & 0.045 \\
\hline Salix exigua & -0.433 & -0.066 & -0.026 & -0.050 & -0.067 \\
\hline $\begin{array}{l}\text { Scirpus } \\
\text { americanus }\end{array}$ & -0.012 & 0.087 & -0.109 & -0.342 & -0.266 \\
\hline $\begin{array}{l}\text { Solidago } \\
\text { occidentalis }\end{array}$ & 0.123 & -0.454 & -0.116 & -0.204 & -0.078 \\
\hline $\begin{array}{l}\text { Xanthium } \\
\text { strumarium }\end{array}$ & 0.292 & 0.171 & -0.430 & $0.310^{\circ}$ & 0.044 \\
\hline
\end{tabular}


Table 14. Principle Components Analysis for Lower Riparian Dominant Species

\begin{tabular}{|c|c|c|c|c|c|}
\hline PC & Eigenvalues & $\%$ Variation & $\begin{array}{l}\text { Cumulative } \\
\% \text { Variation }\end{array}$ & & \\
\hline 1 & 2.94 & 15.5 & 15.5 & & \\
\hline 2 & 2.52 & 13.3 & 28.7 & & \\
\hline 3 & 2.37 & 12.5 & 41.2 & & \\
\hline 4 & 1.89 & 9.9 & 51.1 & & \\
\hline 5 & 1.73 & 9.1 & 60.2 & & \\
\hline Species & PC1 & PC2 & PC3 & $\mathrm{PC}_{4}$ & PC5 \\
\hline $\begin{array}{l}\text { Agropyron } \\
\text { repens }\end{array}$ & 0.150 & -0.002 & -0.320 & -0.132 & -0.305 \\
\hline Carex aquatilis & -0.010 & -0.328 & -0.120 & 0.252 & -0.417 \\
\hline $\begin{array}{l}\text { Cyperus } \\
\text { aristatus }\end{array}$ & 0.407 & -0.068 & 0.152 & -0.292 & 0.068 \\
\hline $\begin{array}{l}\text { Eleocharis } \\
\text { palustris }\end{array}$ & -0.049 & 0.309 & 0.107 & 0.230 & 0.287 \\
\hline $\begin{array}{l}\text { Equisetum } \\
\text { arvense }\end{array}$ & -0.293 & 0.140 & 0.213 & 0.018 & -0.109 \\
\hline $\begin{array}{l}\text { Euphorbia } \\
\text { supina }\end{array}$ & 0.442 & 0.256 & 0.124 & -0.203 & -0.123 \\
\hline $\begin{array}{l}\text { Glycyrrhiza } \\
\text { lepidota }\end{array}$ & -0.226 & -0.187 & 0.103 & -0.141 & -0.167 \\
\hline $\begin{array}{l}\text { Leersia } \\
\text { oryzoides }\end{array}$ & 0.127 & 0.264 & 0.072 & 0.054 & 0.488 \\
\hline Mentha arvensis & -0.120 & 0.207 & -0.456 & -0.263 & 0.115 \\
\hline $\begin{array}{l}\text { Mollugo } \\
\text { verticillata }\end{array}$ & 0.381 & 0.120 & 0.222 & -0.246 & -0.113 \\
\hline $\begin{array}{l}\text { Oxalis } \\
\text { corniculata }\end{array}$ & 0.092 & -0.016 & -0.172 & 0.447 & -0.128 \\
\hline $\begin{array}{l}\text { Phalaris } \\
\text { arundinacea }\end{array}$ & -0.086 & -0.409 & 0.096 & -0.018 & 0.148 \\
\hline $\begin{array}{l}\text { Polygonum } \\
\text { lapathifolium }\end{array}$ & 0.066 & -0.207 & -0.116 & -0.208 & 0.025 \\
\hline Salix exigua & -0.163 & 0.163 & 0.421 & -0.094 & -0.261 \\
\hline $\begin{array}{l}\text { Scirpus } \\
\text { americanus }\end{array}$ & -0.231 & 0.204 & -0.296 & -0.304 & 0.296 \\
\hline $\begin{array}{l}\text { Solidago } \\
\text { occidentalis }\end{array}$ & -0.030 & 0.467 & 0.018 & 0.291 & 0.037 \\
\hline $\begin{array}{l}\text { Xanthium } \\
\text { strumarium }\end{array}$ & 0.364 & -0.118 & -0.130 & 0.281 & 0.258 \\
\hline
\end{tabular}

PC1 accounts for $13.1 \%, 20.4 \%$, and $15.5 \%$ of the data variation in the total, upper, and lower riparian zones, respectively. The most influential sources of data 
variation in $\mathrm{PCl}$ are identical between the total and lower riparian zones: percent of quadrat cover by Cyperus aristatus, Euphorbia supina, Mollugo verticillata, and Xanthium strumarium. Note that $C$. aristatus is not encountered in the upper riparian zone. In the upper riparian zone Equisetum arvense, Glycyrrhiza lepidota, and Salix exigua are the species whose percent of quadrat cover most strongly affected data variability.

PC2 describes $11.1 \%, 16.3 \%$ and $13.3 \%$ of data variation in the total, upper and lower zones, respectively. Agropyron repens, Rumex crispus, and Solidago occidentalis were the most influential for data variation in the total and upper zones, while Carex aquatilis, Phalaris arundinacea, and $S$. occidentalis are the species with greatest influence over data variation in the lower zone. Note that $R$. crispus is not encountered in the lower zone.

PC3 accounts for $10.3 \%, 11.1 \%$, and $12.5 \%$ of data variation for species quadrat cover in the total, upper, and lower riparian zones, respectively. Mostly unique individual species exert the greatest influence on this variability between the analyses for PC3. E. supina, M. verticillata, and S. exigua are the most.influential in the total riparian analysis. $P$. arundinacea, Polygonum lapathifolium, and X. strumarium are the most influential in the upper zone. A. repens, Mentha arvensis, and S. exigua are the most influential in the lower zone.

PC4 explains $8.5 \%, 8.4 \%$, and $9.9 \%$ of species data variability in the total, upper, and lower zones. $M$. arvensis and Scirpus americanus are most influential in the total riparian analysis. Eleocharis palustris and $M$. arvensis are most influential in 
the upper zone. Oxalis corniculata and S. americanus are most influential in the lower zone.

PC5 accounts for $7.8 \%, 7.5 \%$, and $9.1 \%$ of species data variation in the total, upper, and lower zones respectively. There is overlap of highly influential species in PC5 between the total and lower zones, and between the upper and lower zones. In the total riparian analysis $O$. corniculata and $P$. arundinacea are most influential. In the upper zone analysis, $C$. aquatilis and $O$. corniculata are most influential. The most influential species in the lower zone are C. aquatilis and Leersia oryzoides.

\section{Physical Environmental Data}

\section{Soil Horizons}

At all sites sampled, there is no development of $\mathrm{O}$ or $\mathrm{B}$ horizons. The $\mathrm{A}$ horizon at each location is underlain by a $\mathrm{C}$ horizon. The $\mathrm{A}$ horizons are mixtures of sand, silt, clay, and gravel. There is no gleying evident at any of the sites. 13 upper riparian sites and 24 lower riparian sites display redoximorphic features. While some minor soil matrix mottling is evident, the majority of redoximorphic features is limited to oxidized rhizospheres associated with plant roots. The $\mathrm{C}$ horizons are comprised of a matrix of cobbles with a small amount of sand and fine material between them. Attempts were made on numerous occasions to excavate enough of the cobbles to determine if older horizons were beneath them, but this proved impossible with the small hand tools used for the study. 
The mean, standard deviation, and range of values for A horizon depth, average 3 meter slope gradient, $\mathrm{pH}$, and soil texture primary components (percent gravel, sand, silt, and clay) are shown in Table 15. Mann-Whiney test for all .environmental variables compared between the upper and lower riparian zones to test the null hypothesis that there is no difference between zones in terms of environmental variables are shown in Table 16.

\section{Depth of A horizon/Depth to Chorizon}

The A horizon depth varies between 0.003 meter and 0.630 meter, with an average of 0.210 meter across all 60 quadrats. Depth values within the upper and lower riparian zones are highly variable. The upper zone has the greatest range of A horizon depths ( 0.081 to 0.630 meter), with an average depth of 0.291 meter. Average lower zone A horizon depth is 0.128 , with a range of 0.003 to 0.294 meter. The result of the Mann-Whitney test to compare the upper and lower zone is $\mathrm{W}=638$, with a $\mathrm{P}$ value of $<0.0001$. The null hypothesis was rejected in this case. Despite some overlap in values, the depth of the A horizon is statistically different between the upper and lower riparian zones, with the upper zone having generally deeper A horizons.

\section{Average 3 meter slope gradient}

The average slope taken 1 meter above each quadrat, within the quadrat, and 1 meter below the quadrat ranges from $5 \%$ to $44 \%$, with an average of $21 \%$ for all 60 sites. The ranges and means for the slopes of the upper and lower riparian are very 
similar. The upper riparian average slope is $21.2 \%$, and ranges between $5 \%$ and $43 \%$.

Average slope in the lower riparian zone is $21.7 \%$, with a range between $7 \%$ and $44 \%$.

Comparing the slopes of both zones with a Mann-Whitney test yields a U statistic of

930.5 , with a $\mathrm{P}$ value of 0.824 . The null hypothesis that no difference exists between

the slopes of the two zones was accepted.

Table 15. Summary of Environmental Data

\begin{tabular}{|c|c|c|c|c|c|c|c|c|}
\hline & & $\begin{array}{l}\text { Depth to } \\
\text { C } \\
\text { (meters) }\end{array}$ & $\begin{array}{l}\text { Average } \\
\text { Slope \% }\end{array}$ & $\mathrm{pH}$ & $\begin{array}{l}\% \\
\text { Gravel }\end{array}$ & $\begin{array}{l}\% \\
\text { Sand }\end{array}$ & $\begin{array}{l}\% \\
\text { Silt }\end{array}$ & $\begin{array}{l}\% \\
\text { Clay }\end{array}$ \\
\hline \multirow[t]{2}{*}{ Mean } & Upper & 0.29 & 20.20 & 6.51 & 3.19 & 72.72 & 21.46 & 2.43 \\
\hline & Lower & 0.13 & 21.70 & 6.65 & 7.39 & 78.97 & 15.79 & 1.93 \\
\hline \multirow{2}{*}{$\begin{array}{l}\text { Standard } \\
\text { Deviation }\end{array}$} & Upper & 0.16 & 9.80 & 0.43 & 8.17 & 10.34 & 9.23 & 0.98 \\
\hline & Lower & 0.09 & 11.02 & 0.57 & 12.67 & 14.41 & 12.93 & 1.15 \\
\hline \multirow{2}{*}{$\begin{array}{l}\text { Range - } \\
\text { Low End }\end{array}$} & Upper & 0.08 & 5.00 & 5.50 & 0.00 & 49.58 & 2.79 & 0.80 \\
\hline & Lower & 0.00 & 7.00 & 5.20 & 0.00 & 36.69 & 1.57 & 0.59 \\
\hline \multirow{2}{*}{$\begin{array}{l}\text { Range - } \\
\text { High End }\end{array}$} & Upper & 0.63 & 43.00 & 7.30 & 35.74 & 92.99 & 43.47 & 5.23 \\
\hline & Lower & 0.29 & 44.00 & 7.50 & 52.73 & 95.55 & 53.88 & 4.96 \\
\hline
\end{tabular}

'Clay, silt, and sand values are a percentage by weight of $50 \mathrm{~g}$ soil samples that did not include gravel. The gravel was removed prior to measuring out the $50 \mathrm{~g}$.

Table 16. Mann-Whitney Test Results for Environmental Variables

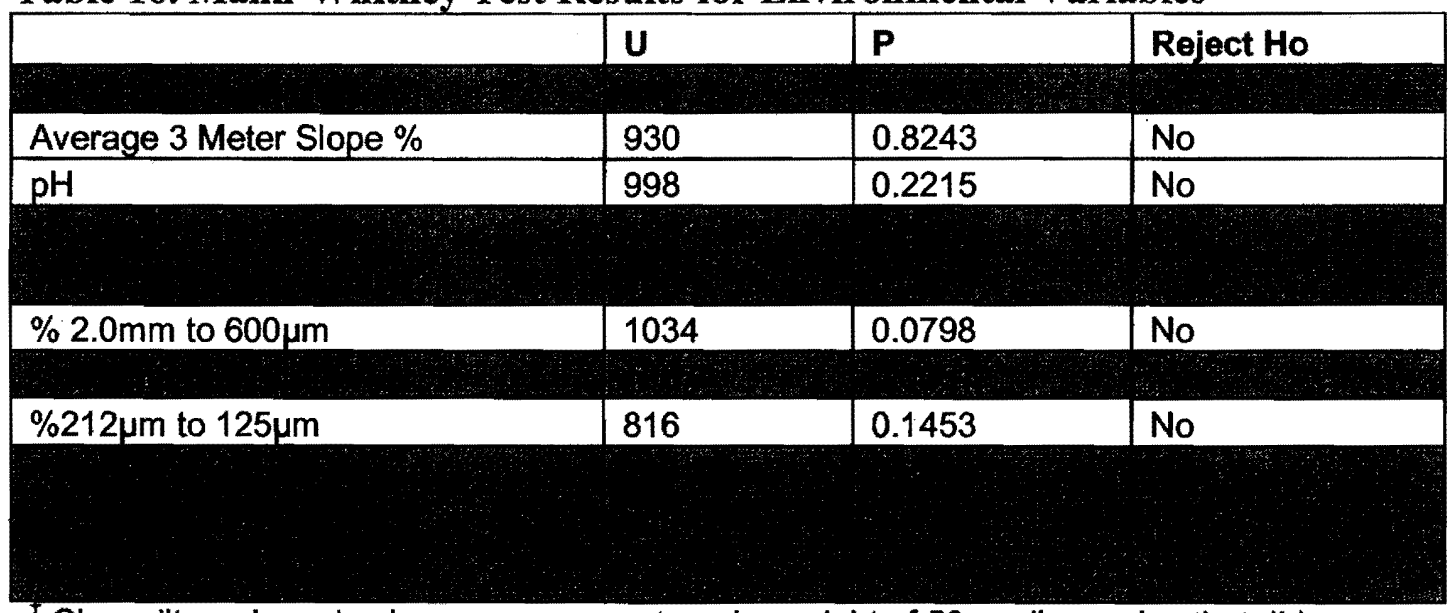

Clay, silt, and sand values are a percentage by weight of $50 \mathrm{~g}$ soil samples that did not include gravel. The gravel was removed prior to measuring out the $50 \mathrm{~g}$ samples.

Shaded cells contain variables for which the $\mathrm{H}_{0}$ was rejected. 


\section{$\underline{\text { Soil pH}}$}

Soil in this riparian zone tends to be somewhat acidic, although a few soil samples are very slightly basic. Over all 60 sites, the average $\mathrm{pH}$ value is 6.6 , with a range between 5.2 and 7.5. Descriptive statistics of the two zones show a great deal of overlap. The average upper and lower riparian $\mathrm{pH}$ are 6.5 and 6.6 , respectively. The upper riparian soil $\mathrm{pH}$ range is 5.5 to 7.3 , and the lower riparian range is 5.2 to 7.5 . Results of the Mann-Whitney test performed on the two zones' $\mathrm{pH}$ values accepted the null hypothesis, with a $\mathrm{U}$ value of 998.0 and a $\mathrm{P}$ value of 0.222 . Soil $\mathrm{pH}$ is not statistically different between the two zones.

\section{$\underline{\text { Soil Texture }}$}

\section{Minimal Percent Gravel}

Minimal percent gravel in the riparian zone ranges from $0 \%$ to $52.73 \%$, with an average of $5.29 \%$. The lower riparian zone has the greatest variability $(0 \%$ to $52.73 \%)$ and the highest average of percent gravel values $(7.39 \%)$. Upper riparian values range from $0 \%$ to $35.74 \%$, with an average of $3.19 \%$ gravel. Mann-Whitney test results show a $U$ value of 10.52 , with a $P$ value of 0.0436 . The null hypothesis was rejected, and the percent gravel is different between the upper and lower riparian zones. Gravel percentage is higher in the lower riparian soils. 


\section{Percent sand}

The soils included in the survey tend to be sandy, although there is a great deal of variation throughout the riparian zone, and within the upper and lower zones. Average sand content by weight is $75.85 \%$ for the entire riparian zone, and ranges from $36.69 \%$ to $95.54 \%$ across all 60 sites. Although some of the sites have markedly low sand content compared to the others, the overall sand content is generally high. The upper riparian zone demonstrates less variability than the lower zone, with sand percentage ranging between $49.58 \%$ and $92.99 \%$. The range of sand content for all sites is determined by the variability of sand content in the lower riparian zone ( $36.69 \%$ to $95.54 \%$ ). The upper zone averages $72.72 \%$ sand, while the lower zone averages $78.97 \%$ sand. Mann-Whitney results for percent sand between the sites include a $U$ value of 1098.0 , and a $P$ value of 0.007 . According to this test the two zones have significantly different percentages of sand, with the lower zone being somewhat sandier than the upper zone.

Results of the sand texture analysis follow. The values given represent the percentage of the total soil sample used for texture analysis, not percentages of the sand fraction only. Mean, standard deviation, and range of values for each sand component are shown in Table 17.

Two of the four categories of sand size have significant differences between the upper and lower riparian soils, according to the Mann-Whitney tests performed (Table 16). The lower riparian soils show a statistically higher percentage coarser grained sand $(600 \mu \mathrm{m}$ to $212 \mu \mathrm{m})$, while the upper riparian soils show a statistically 
higher percentage of finer grained sand $(125 \mu \mathrm{m}$ to $63 \mu \mathrm{m})$. While the results above show that the lower riparian soils are somewhat sandier than the upper riparian soils, the results of the analyses below demonstrate that the lower riparian soils also tend to have coarser sand texture than the upper riparian soils. This illustrates an overall pattern fining of soil particles moving away from the stream channel.

Table 17. Summary of Sand Fraction Analysis

\begin{tabular}{|c|c|c|c|c|c|}
\hline & & $\begin{array}{l}\% 2.0 \mathrm{~mm} \text { to } \\
600 \mu \mathrm{m}\end{array}$ & $\begin{array}{l}\% 600 \mu \mathrm{m} \text { to } \\
212 \mu \mathrm{m}\end{array}$ & $\begin{array}{l}\% 212 \mu \mathrm{m} \text { to } \\
125 \mu \mathrm{m}\end{array}$ & $\begin{array}{l}\% 125 \mu \mathrm{m} \\
\text { to } 63 \mu \mathrm{m}\end{array}$ \\
\hline \multirow{2}{*}{ Mean } & Upper & 2.95 & 29.35 & 21.96 & 18.46 \\
\hline & Lower & 5.82 & 40.08 & 19.80 & 13.27 \\
\hline \multirow{2}{*}{$\begin{array}{l}\text { Standard } \\
\text { Deviation }\end{array}$} & Upper & 2.92 & 12.69 & 6.35 & 5.53 \\
\hline & Lower & 6.33 & 18.54 & 6.26 & 6.39 \\
\hline \multirow{2}{*}{$\begin{array}{l}\text { Range - Low } \\
\text { End }\end{array}$} & Upper & 0.31 & 7.54 & 7.34 & 10.60 \\
\hline & Lower & 0.46 & 9.54 & 10.64 & 3.05 \\
\hline \multirow{2}{*}{$\begin{array}{l}\text { Range - High } \\
\text { End }\end{array}$} & Upper & 14.50 & 49.31 & 40.29 & 28.58 \\
\hline & Lower & 25.65 & 74.77 & 38.57 & 27.53 \\
\hline
\end{tabular}

${ }^{\top}$ Clay, silt, and sand values are a percentage by weight of $50 \mathrm{~g}$ soil samples that did not include gravel. The gravel was removed prior to measuring out the $50 \mathrm{~g}$ samples.

\section{Percent sand-between $2.0 \mathrm{~mm}$ and $600 \mu \mathrm{m}$}

Total riparian percentage of sand between $2.0 \mathrm{~mm}$ and $600 \mu \mathrm{m}$ averages $4.39 \%$ and varies between $0.31 \%$ and $25.65 \%$. The upper riparian zone appeares to have generally less of this coarse sand, with an average of $2.95 \%$, while the lower riparian zone averages $5.82 \%$. The upper zone has less coarse sand variability, with values ranging between $0.31 \%$ and $14.50 \%$. The lower zone ranges from $0.46 \%$ to $25.65 \%$. Despite apparent differences, the Mann-Whitney test accepted the null hypothesis that there is no difference, with a $U$ value of 1034.0 and a $P$ value of 0.0798 . 


\section{Percent sand-between $600 \mu \mathrm{m}$ and $212 \mu \mathrm{m}$}

Average sand content between $600 \mu \mathrm{m}$ and $212 \mu \mathrm{m}$ for the entire riparian zone is $34.71 \%$ and ranges between $7.54 \%$ and $74.77 \%$. Upper riparian soil averages $29.35 \%$, while the lower riparian soil averages $40.08 \%$ sand in this size range. The upper riparian soil shows less variation of values, ranging from $7.53 \%$ to $49.31 \%$, whereas the lower riparian soil ranges from $9.54 \%$ to $74.77 \%$ sand between $600 \mu \mathrm{m}$ and $212 \mu \mathrm{m}$. The Mann-Whitney $U$ statistic value was 1067.0 , with a $P$ value of 0.0251. The null hypothesis was rejected, indicating a statistically significant difference between the two zones for sand in this size range.

Percent sand - between $212 \mu \mathrm{m}$ and $125 \mu \mathrm{m}$

Over all 60 sample sites, the average percentage of sand between $212 \mu \mathrm{m}$ and $125 \mu \mathrm{m}$ is $20.88 \%$, with a range between $7.34 \%$ and $40.29 \%$. The total range mirrors that of the upper riparian zone soils, which averages $21.96 \%$ sand of this size. Variability of the lower riparian soils is slightly less, with a range of $10.64 \%$ to $38.57 \%$, and an average of $19.80 \%$. The $U$ statistic resulting from the Mann-Whitney test is 816.0 , with an associated $P$ value of 0.1453 . The null hypothesis for this size of sand was accepted, indicating that the upper and lower riparian zones are the same in terms of this variable. 


\section{Percent sand-between $125 \mu \mathrm{m}$ and $63 \mu \mathrm{m}$}

The average value of the finest category of sand analyzed is $15.87 \%$ for the entire riparian zone. The overall range of values is between $3.05 \%$ and $28.58 \%$ of the soil samples. Samples from the upper riparian zone range from $10.60 \%$ to $28.58 \%$ and -average $18.46 \%$. The lower riparian values range from $3.05 \%$ to $27.53 \%$ and average $13.27 \%$. The $\mathrm{U}$ statistic resulting from the Mann-Whitney test is 720.0 , with a $\mathrm{P}$ value of 0.0040 . This shows that the upper riparian soil has a statistically greater proportion of sand in this size range than does the lower riparian soil.

\section{Percent Silt}

Percent silt is highly variable. The range of values over all 60 sample sites is $1.57 \%$ to $53.88 \%$, with an average of $18.63 \%$. Both the upper and lower riparian soils demonstrate a high degree of variability, however it is somewhat less in the upper zone. Upper riparian soils range from $2.79 \%$ to $43.47 \%$ silt, while the range of lower riparian values is identical to the range for the entire study area. The average upper riparian value is $21.46 \%$ silt, and the average lower riparian value is $15.79 \%$. The Mann-Whitney $U$ statistic is 725.0 , with a $P$ value of 0.0051 . The null hypothesis was rejected, indicating that the two zones are statistically different; with the upper riparian containing significantly more silt than the lower riparian soils. 


\section{Percent Clay}

Clay is a small component of all soils surveyed in this study. The average clay content for all 60 sample sites iss $2.18 \%$, and ranges between $0.59 \%$ and $5.23 \%$. The upper riparian soils average $2.43 \%$ clay, while the lower riparian soils average $1.93 \%$ clay. Variability of values across the entire studied riparian zone, as well as within the two zones is small. The range of upper riparian values is $0.80 \%$ to $5.23 \%$, and the range of lower riparian values is $0.59 \%$ to $4.96 \%$ clay. The Mann-Whitney test results in a $U$ value of 766.0 , with a $P$ value of 0.0281 . The null hypothesis that the two zones have the same clay content was therefore rejected. Clay content in the upper riparian soils is significantly greater than that of the lower riparian soils.

\section{Multivariate Analyses}

Figure 11 shows an MDS plot, which visually represents the statistical distance between each quadrat and each other quadrat, based on the environmental variable values at each site. This plot shows less overlap between upper zone sites and lower zone sites than the species MDS plot shows. Clustering is evident, indicating a tendency for upper zone sites to be overall more similar to other upper zone sites than to lower zone sites. Despite the clustering, there is still some degree of overlap, indicating that the site groupings are not radically different based on zone. The upper zone sites tend to be more tightly clustered, while the lower zone sites are more spread out over the plot. This demonstrates, and the descriptive data confirms, that when all 
variables are considered, the lower zone has more highly variable measurements and data.

Several individual environmental variables display statistical differences between the upper and lower riparian zones. ANOSIM analysis was performed to examine the differences between upper and lower sites based on an aggregation of variability of all of the environmental variables studied (A horizon depth, average three-meter slope, $\mathrm{pH}$, and soil texture). The resulting $R$ value is 0.102 , with a $\mathrm{P}$ value of 0.004 . The null hypothesis that the upper and lower zones are the same, considering all environmental data available, was rejected, indicating a difference between the studied upper and lower environmental characteristics.

Principle components analysis (PCA) was performed on the environmental data to determine which variables exert the most control over variance in the environmental variables. The entire riparian, the upper riparian, and the lower riparian zones were analyzed twice each: once with the stratified sand texture data included, once with the total sand value included. In each case, the analyses that did not stratify sand sizes were able to describe considerably more of the overall variance. For the remainder of the PCA discussion only the data with the total sand values were used. Conducting analyses for the entire riparian zone and for the upper and lower zones facilitated a comparison of the sources of variance at two different scales, and within the two zones that ANOSIM identified as statistically different from each other. A summary of the principle components and the eigenvectors for each is presented in Table 18, Table 19, and Table 20. 


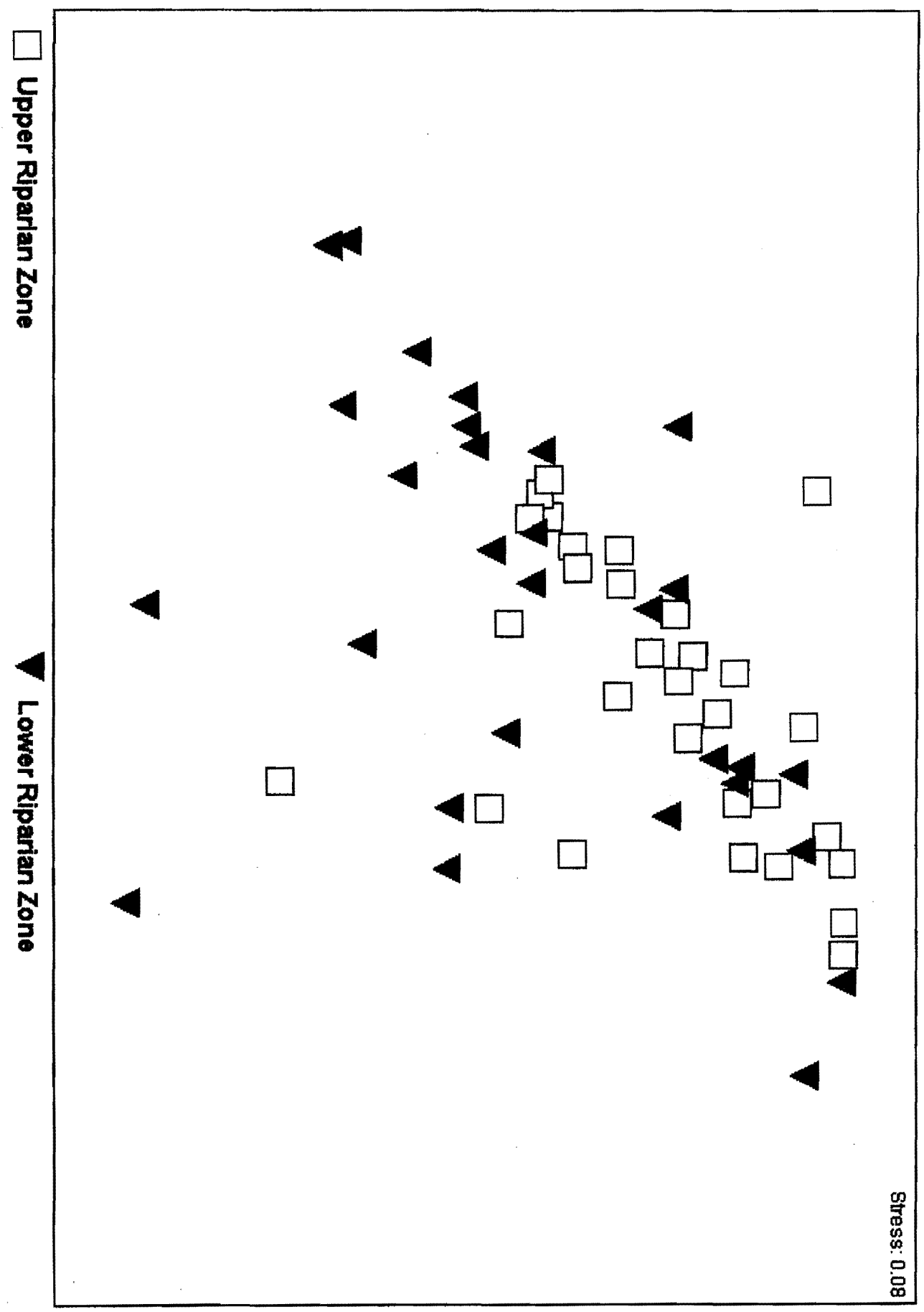

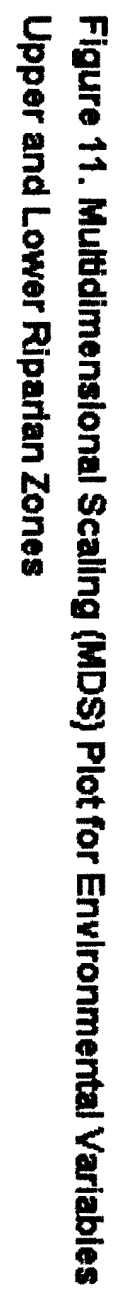


Table 18. Principal Components Analysis for Total Riparian Zone Environmental Variables

\begin{tabular}{|c|c|c|c|c|c|}
\hline PC & Eigenvalues & $\%$ Variation & $\begin{array}{l}\text { Cumulative } \\
\text { \%Variation }\end{array}$ & & \\
\hline 1 & 2.83 & 40.5 & 40.5 & & \\
\hline 2 & 1.41 & 20.2 & 60.7 & & \\
\hline 3 & 1.06 & 15.1 & 75.8 & & \\
\hline 4 & 0.96 & 13.7 & 89.5 & & \\
\hline 5 & 0.52 & 7.4 & 96.9 & & \\
\hline & PC1 & PC2 & PC3 & PC4 & PC5 \\
\hline A Horizon Depth & -0.117 & 0.7 & -0.078 & 0.194 & 0.652 \\
\hline Average $3 \mathrm{~m}$ Slope & -0.105 & 0.484 & -0.648 & -0.233 & -0.516 \\
\hline $\mathrm{pH}$ & 0.114 & -0.358 & -0.619 & 0.605 & 0.068 \\
\hline \%Gravel & 0.227 & -0.282 & -0.399 & -0.682 & 0.494 \\
\hline \%Sand & 0.568 & 0.177 & 0.11 & -0.034 & -0.134 \\
\hline$\%$ Silt & -0.561 & -0.178 & -0.115 & 0.066 & 0.158 \\
\hline \%Clay & -0.523 & -0.071 & 0.082 & -0.268 & -0.128 \\
\hline
\end{tabular}

Table 19. Principal Components Analysis for Upper Riparian Zone Environmental Variables

\begin{tabular}{|l|l|l|l|l|l|}
\hline PC & Eigenvalues & \%Variation & $\begin{array}{l}\text { Cumulative } \\
\text { \%Variation }\end{array}$ & & \\
\hline 1 & 2.81 & 40.2 & 40.2 & & \\
\hline 2 & 1.57 & 22.4 & 62.6 & & \\
\hline 3 & 1.18 & 16.9 & 79.5 & & \\
\hline 4 & 0.94 & 13.4 & 93 & & \\
\hline 5 & 0.36 & 5.2 & 98.1 & & \\
\hline \multicolumn{7}{|l|}{} \\
\hline \multicolumn{7}{|l|l|l|l|l|l|}{} \\
\hline A Horizon Depth & PC1 & PC2 & PC3 & PC4 & PC5 \\
\hline Average 3 m Slope & 0.204 & 0.539 & 0.265 & 0.548 & 0.48 \\
\hline pH & 0.059 & -0.19 & 0.2 & -0.105 & -0.649 \\
\hline \%Gravel & 0.144 & 0.407 & -0.8 & -0.41 & -0.009 \\
\hline \%Sand & 0.563 & -0.184 & -0.15 & -0.696 & 0.357 \\
\hline \%Silt & -0.553 & 0.182 & 0.193 & 0.101 & -0.156 \\
\hline \%Clay & -0.53 & 0.133 & -0.211 & -0.107 & 0.217 \\
\hline
\end{tabular}


Table 20. Principal Components Analysis for Lower Riparian Zone Environmental Variables

\begin{tabular}{|l|l|l|l|l|l|}
\hline PC & Eigenvalues & \%Variation & $\begin{array}{l}\text { Cumulative } \\
\text { \%Variation }\end{array}$ & & \\
\hline 1 & 2.92 & 41.7 & 41.7 & & \\
\hline 2 & 1.74 & 24.9 & 66.6 & & \\
\hline 3 & 0.93 & 13.3 & 79.9 & & \\
\hline 4 & 0.84 & 11.9 & 91.9 & & \\
\hline 5 & 0.33 & 4.8 & 96.6 & & \\
\hline \multicolumn{7}{|l|}{} & PC2 & PC3 & PC4 & PC5 \\
\hline & PC1 & 0.663 & 0.225 & -0.037 & 0.701 \\
\hline A Horizon Depth & -0.085 & 0.318 & 0.365 & 0.696 & -0.381 \\
\hline Average 3 m Slope & -0.283 & -0.366 & 0.87 & -0.138 & 0.03 \\
\hline pH & 0.096 & -0.366 & -0.109 & 0.636 & 0.549 \\
\hline \%Gravel & 0.246 & -0.463 & -0.035 & 0.131 & -0.175 \\
\hline \%Sand & 0.545 & 0.226 & -0.035 & -0.165 & 0.176 \\
\hline \%Silt & -0.537 & -0.229 & 0.042 & -215 & -0.009 \\
\hline \%Clay & -0.508 & -0.096 & -0.211 & 0.215 & \\
\hline
\end{tabular}

Principle component (PC) 1 has similar characteristics in each of the datasets. Variation represented by this $\mathrm{PC}$ is $40.5 \%, 40.2 \%$, and $41.7 \%$ for the total, upper, and lower riparian zones respectively. In all three datasets, the variables with the greatest influence on variance are sand, silt, and clay: collectively soil texture.

PC 2 represents $20.2 \%, 22.4 \%$, and $24.9 \%$ of variance in the total, upper, and lower riparian zones respectively. For the total riparian and lower riparian zones, depth of the A horizon represents the greatest variance. Slope is most significant for PC 2 values in the upper riparian zone, and second most for the total riparian zone. Percent gravel strongly influences data variance for PC 2 in the upper and lower riparian datasets, but is much less significant for the total riparian zone.

PC 3 represents $15.1 \%, 16.9 \%$, and $13.3 \%$ of variance in the total, upper, and lower riparian datasets. $\mathrm{pH}$ is the most important factor for this $\mathrm{PC}$ in all three zones. 
However, when the entire riparian zone is examined, slope is also a very strong contributor to variation.

PC 4 represents $13.7 \%, 13.4 \%$, and $11.9 \%$ of variance in the total, upper, and lower riparian datasets respectively. Percent gravel exerts the greatest influence for the total and upper riparian datasets. It is also a strong vector in the lower riparian dataset. Slope is very influential in the lower riparian dataset, but has considerably smaller effects on the total and upper riparian dataset variances. Similarly, depth of the A horizon represents a great deal of variability for the upper riparian data set, but very little for the other two sets, while $\mathrm{pH}$ is a strong contributor in the total riparian dataset, a moderate contributor in the upper set, and a very weak contributor in the lower set.

PC 5 represents $7.4 \%, 5.2 \%$, and $4.8 \%$ of the variance in the total, upper, and lower riparian datasets respectively. Depth of the A horizon has the greatest influence on variance in the total and lower riparian datasets, and is moderately significant in the upper riparian set. Slope is most significant for the upper riparian set, and strongly influences variability of this $\mathrm{PC}$ in the total riparian set. Percent gravel is relatively important in all three datasets; however it is notably more significant for the total and lower datasets than for the upper dataset.

\section{Single Linear Regressions-Plant-Environmental Variable Relationships}

Table 21 through Table 24 summarize the results of single linear regressions performed for each dominant species compared to each environmental variable, for the 
total, upper, and lower riparian zones. The nature of the significant relationships positive or negative - is displayed. Shaded cells without such indicators represent regressions that are not significant, with a $P$ value greater than 0.05 . The data are further presented, by species and with statistical data values, in figures A-1 through Table A-17 in Appendix A. Seventeen dominant species have at least one significant relationship with an environmental variable, while only one species, Carex aquatilis, does not demonstrate any significant environmental relationships. Several instances occur in which only clay has a significant relationship with a plant species, while neither silt nor total sand does. However, in all instances in which total sand has a significant vegetation relationship, silt and clay also have a significant relationship. The correlation between plants and silt/clay is always opposite the correlation with total sand (e.g. if total sand has a positive relationship, silt and clay always have a negative relationship).

This study was designed and implemented to determine whether a riparianwide approach to management and analysis of riparian zones is appropriate, rather than to establish the causality of plant-environmental relationships. Therefore, detailed results for regressions involving only the five species that demonstrate the greatest amount of cover (Xanthium strumarium, Phalaris arundinacea, Equisetum arvense, Carex aquatilis, and Scirpus americanus) will be presented in the text. However, summaries of all regressions with significant relationships are presented in Table 21 through Table 24. X. strumarium has significant relationships with depth of the A horizon over the entire study area (positive correlation, $P=0.023, \mathrm{R}^{2}=0.07$ ) and in 
the lower riparian zone (positive correlation, $\mathrm{P}=0.003, \mathrm{R}^{2}=0.252$ ); with the average 3 meter slope only in the total riparian area (positive correlation, $P=0.032, \mathrm{R}^{2}=$ 0.061 ); with sand between $2.0 \mathrm{~mm}$ and $600 \mu \mathrm{m}$ in both the total riparian zone (negative correlation, $\mathrm{P}=0.002, \mathrm{R}^{2}=0.134$ ) and the lower riparian zone (negative correlation, $\mathrm{P}$ $=0.018, \mathrm{R}^{2}=0.156$ ); with sand between $600 \mu \mathrm{m}$ and $212 \mu \mathrm{m}$ in both the total riparian (positive correlation, $\mathrm{P}=0.047, \mathrm{R}^{2}=0.05$ ) and lower riparian zones (positive correlation, $P=0.07, R^{2}=0.206$ ); with sand between $125 \mu \mathrm{m}$ and $63 \mu \mathrm{m}$ in the lower riparian zone only (negative correlation, $\mathrm{P}=0.024, \mathrm{R}^{2}=0.14$ ); and with $\mathrm{pH}$ in the lower riparian zone (negative correlation, $\mathrm{P}=0.026, \mathrm{R}^{2}=0.135$ ). See Table A-1 (Appendix A) for a summary of $X$. strumarium regressions.

P. arundinacea is the most dominant species in the upper riparian zone and the second most dominant species for the total study area. There are significant relationships between this plant and the depth of the A horizon in both the total study area (positive correlation, $\mathrm{P}<0.001, \mathrm{R}^{2}=0.259$ ) and in the upper riparian zone (positive correlation, $\mathrm{P}=0.049, \mathrm{R}^{2}=0.10$ ); and with the percent of soil between $125 \mu \mathrm{m}$ and $63 \mu \mathrm{m}$ for the total riparian zone (positive correlation, $\mathrm{P}=0.038, \mathrm{R}^{2}=$ $0.056) . P$. arundinacea displays no significant relationships with any of the studied environmental variables in the lower riparian zone. The plant's relationship with the depth of the A horizon is very important for the entire study area, but is apparently much less so in the upper and lower riparian zones as individual systems $\left(\mathrm{R}^{2}=0.259\right.$, 0.10 , and insignificant, respectively). Table A-2 summarizes relationships between $P$. arundinacea and environmental variables. 
E. arvense has the third greatest cover for the entire study area and upper riparian zone, and the second greatest for the lower riparian zone. This plant has significant relationships with the depth of the A horizon in the total riparian zone (negative correlation, $\mathrm{P}=0.009, \mathrm{R}^{2}=0.096$ ); with the average 3 meter slope in the upper riparian zone (negative correlation, $P=0.015, R^{2}=0.165$ ); with percent clay in the upper riparian zone (positive correlation, $\mathrm{P}=0.018, \mathrm{R}^{2}=0.156$ ); with percent of soil between $2.0 \mathrm{~mm}$ and $600 \mu \mathrm{m}$ in the total riparian zone (positive correlation, $\mathrm{P}=$ $0.008, \mathrm{R}^{2}=0.10$ ); and with percent of soil between $600 \mu \mathrm{m}$ and $212 \mu \mathrm{m}$ (negative correlation, $P=0.05, R^{2}=0.099$ ) and percent of soil between $125 \mu \mathrm{m}$ and $63 \mu \mathrm{m}$ (positive correlation, $\mathrm{P}=0.035, \mathrm{R}^{2}=0.119$ ) in the lower riparian zone. E. arvense does not have any relationships with environmental variables that are similar between the upper and lower floodplains. Regressions performed for the entire riparian zone establish two significant relationships at that scale. However, the relationships that are apparent between this important riparian plant and environmental variables within the upper and lower zones are lost completely when looking only at the entire riparian area dataset. Table A-3 summarizes $E$. arvensis and environmental variable regressions.

C. aquatilis does not have any significant relationships with any of the environmental variable studied. S. americanus has a single significant relationship: depth of the A horizon is positively correlated with S. americanus quadrat cover for the entire riparian area $\left(P=0.025, R^{2}=0.068\right)$. No significant relationships are 
identified in the upper or lower riparian zone alone between this plant and the studied environmental variables (Table A-4).

Depth of the A horizon has more significant relationships with dominant species quadrat cover than any other single environmental variable (17 total). Surface slope displays ten significant relationships with species cover, and percent of soil between $600 \mu \mathrm{m}$ and $212 \mu \mathrm{m}$ had eight such relationships. Percent clay has six total significant species cover relationships. $\mathrm{pH}$ has only one significant relationship with species quadrat cover.

Regressions performed for species quadrat cover, but grouped by wetland indicator status, give additional insights into relationships between environmental variables and plants. A summary table for these relationships is shown in Table 25 . Table A-18 through Table A-21 in Appendix A show the details of the significant relationships between the environmental variables and OBL, FACW, FACU, and UPL plant cover. There are no significant relationships between the environmental variables studied and FAC plant cover. FACU quadrat cover is positively correlated with the average 3 meter slope for the entire study area $\left(P=0.007, R^{2}=0.103\right)$ and in the lower riparian zone $\left(P=0.006, R^{2}=0.211\right)$. Percent gravel is positively correlated with FACU quadrat cover when the entire study area was analyzed $\left(P=0.040, R^{2}=\right.$ 0.055). UPL quadrat cover has significant relationships with environmental variables only at the riparian-wide scale, and both relationships are with stratified sand texture categories: percent of soil between $600 \mu \mathrm{m}$ and $212 \mu \mathrm{m}$ (positive correlation, $\mathbf{P}=0.005$, 
$\mathrm{R}^{2}=0.115$ ), and percent of soil between $125 \mu \mathrm{m}$ and $63 \mu \mathrm{m}$ (negative correlation, $\mathrm{P}=$ $\left.0.010, \mathrm{R}^{2}=0.093\right)$.

OBL quadrat cover has significant negative relationships with depth of the $A$ horizon and the percent of soil between $125 \mu \mathrm{m}$ and $63 \mu \mathrm{m}$ across the entire riparian area $\left(P<0.001, R^{2}=0.204\right.$ and $P=0.040, R^{2}=0.054$, respectively), but not in either the upper or lower riparian zone. The average 3 meter slope has a significant negative relationship with $\mathrm{OBL}$ cover in the upper riparian zone only $\left(\mathrm{P}=0.034, \mathrm{R}^{2}=0.120\right)$. Percent clay has a significant relationship with $\mathrm{OBL}$ cover in the lower riparian zone only (positive correlation, $\mathrm{P}=0.014, \mathrm{R}^{2}=0.167$ ). The slope and clay relationships are only apparent when analyzing the data stratified between the upper and lower zones.

Significant relationships exist between FACW quadrat cover and the depth of the A horizon in both the entire riparian (positive correlation, $\mathrm{P}<0.001, \mathrm{R}^{2}=0.234$ ) and in the upper riparian zones (positive correlation, $\mathrm{P}=0.038, \mathrm{R}^{2}=0.114$ ). Percent gravel has a significant negative relationship with FACW species cover $\left(P=0.037, R^{2}\right.$ $=0.116)$ in the lower riparian zone. Percent of soil between $212 \mu \mathrm{m}$ and $125 \mu \mathrm{m}$ has significant relationships with FACW cover in the entire study are (positive correlation, $\mathrm{P}=0.034, \mathrm{R}^{2}=0.049$ ) and in the lower riparian zone (positive correlation, $\mathrm{P}=0.039$, $\left.\mathrm{R}^{2}=0.113\right)$. 
Table 21. Summary of Dominant Species \% Quadrat Cover vs. Environmental Variable Single Linear Regressions, Part 1 of 4

\begin{tabular}{|c|c|c|c|c|c|c|c|c|c|c|c|c|}
\hline \multirow[b]{2}{*}{ Species } & \multirow[b]{2}{*}{ Zone } & \multicolumn{6}{|c|}{ Relationships: + (Positive) } & \multicolumn{5}{|c|}{ Shaded (No Relationship, $P>0.05$ ) } \\
\hline & & $\begin{array}{c}\text { A } \\
\text { Horizon } \\
\text { Depth }\end{array}$ & $\begin{array}{l}\text { Average } \\
3 \text { Meter } \\
\text { Slope \% }\end{array}$ & $\mathrm{pH}$ & $\begin{array}{c}\% \\
\text { Gravel }\end{array}$ & $\stackrel{\%}{\text { Sand }}$ & $\begin{array}{c}\% \\
\text { silt }\end{array}$ & Clay $^{\%}$ & $\begin{array}{c}\% 2.0 \mathrm{~mm} \\
\text { to } \\
600 \mathrm{um}^{\dagger}\end{array}$ & $\begin{array}{c}\% 600 \mu \mathrm{m} \\
\text { to } \\
212 \mu \mathrm{m}^{t}\end{array}$ & $\begin{array}{c}\% 212 \mu \mathrm{m} \\
\text { to } \\
125 \mathrm{um}^{\dagger}\end{array}$ & $\begin{array}{c}\% \\
125 \mu m \\
\text { to } \\
63 \mathrm{~m}^{+}\end{array}$ \\
\hline \multirow{3}{*}{$\begin{array}{l}\text { Agropyron } \\
\text { repens }\end{array}$} & All Sites & + & + & & & & & & & & & \\
\hline & Upper & & + & & & & & & & & & \\
\hline & Lower & & & & & & & & & & & \\
\hline \multirow{3}{*}{$\begin{array}{l}\text { Carex } \\
\text { aquatilis }\end{array}$} & All Sites & & & & & & & & & & & \\
\hline & Upper & & & & & & & & & & & \\
\hline & Lower & & & & & & & & & & & \\
\hline \multirow{3}{*}{$\begin{array}{l}\text { Cyperus } \\
\text { aristatus }\end{array}$} & All Sites & & & & & & & & & + & & - \\
\hline & Upper & & & & & & & & & & & \\
\hline & Lower & & & & & & & & & + & & \\
\hline \multirow{3}{*}{$\begin{array}{l}\text { Eleocharis } \\
\text { Palustris }\end{array}$} & All Sites & & & & & - & + & + & & & & \\
\hline & Upper & & & & & & & & & & & \\
\hline & Lower & & & & & - & + & + & & & & \\
\hline \multirow{3}{*}{$\begin{array}{l}\text { Equisetum } \\
\text { arvense }\end{array}$} & All Sites & - & & & & & & & + & & & \\
\hline & Upper & & - & & & & & + & & & & \\
\hline & Lower & & & & & & & & & - & & + \\
\hline
\end{tabular}

${ }^{\dagger}$ Clay, silt, and sand values are a percentage by weight of $50 \mathrm{~g}$ soil samples with gravel removed prior to analysis. 
Table 22. Summary of Dominant Species \% Quadrat Cover vs Environmental Variable Single Linear Regressions, Part 2 of 4

\begin{tabular}{|c|c|c|c|c|c|c|c|c|c|c|c|c|}
\hline \multirow[b]{2}{*}{ Species } & \multirow[b]{2}{*}{ Zone } & \multicolumn{7}{|c|}{ Relationships: + (Positive) - (Negative) } & \multicolumn{4}{|c|}{ Shaded (No Relationship, P > 0.05) } \\
\hline & & $\begin{array}{c}\text { A } \\
\text { Horizon } \\
\text { Depth }\end{array}$ & $\begin{array}{l}\text { Average } \\
3 \text { Meter } \\
\text { Slope \% }\end{array}$ & $\mathbf{p H}$ & $\begin{array}{c}\% \\
\text { Gravel }\end{array}$ & $\begin{array}{c}\% \\
\text { Sand }\end{array}$ & silt $^{\dagger}$ & clay $^{\%}$ & $\begin{array}{c}\% 2.0 \mathrm{~mm} \\
\text { to } \\
600 \mathrm{um}^{\dagger}\end{array}$ & $\begin{array}{c}\% 600 \mu m \\
\text { to } \\
212 \mathrm{um}^{\dagger}\end{array}$ & $\begin{array}{c}\% 212 \mu \mathrm{m} \\
\text { to } \\
125 \mathrm{~mm}^{\dagger}\end{array}$ & $\begin{array}{l}\% 125 \mu \mathrm{m} \\
\text { to } 63 \mathrm{~mm}^{\dagger}\end{array}$ \\
\hline \multirow{3}{*}{$\begin{array}{l}\text { Euphorbia } \\
\text { supina }\end{array}$} & Al Sites & & & & & & & & & & & \\
\hline & Upper & & & & & & & & & & & \\
\hline & Lower & + & & & & & & & & & & \\
\hline \multirow{3}{*}{$\begin{array}{l}\text { Glycymhiza } \\
\text { lepidota }\end{array}$} & Al Sites & - & - & & & & & & & & & \\
\hline & Upper & - & . & & & & & & & & & \\
\hline & Lower & - & - & & & & & & & & & \\
\hline \multirow{3}{*}{$\begin{array}{l}\text { Leersia } \\
\text { oryzoides }\end{array}$} & All Sites & & & & & & & & & & & \\
\hline & Upper & & & & & & & & & & & \\
\hline & Lower & + & & & & & & & & & & \\
\hline \multirow{3}{*}{$\begin{array}{l}\text { Mentha } \\
\text { arvensis }\end{array}$} & All Sites & - & & & & & & & & & & \\
\hline & Upper & & & & & & & & & & & \\
\hline & Lower & & & & & & & & & & & \\
\hline \multirow{3}{*}{$\begin{array}{l}\text { Mollugo } \\
\text { verticillata }\end{array}$} & All Sites & & & & & & & & & + & - & \\
\hline & Upper & & & & & & & & & & & \\
\hline & Lower & + & & & & & & & & & & \\
\hline
\end{tabular}

${ }^{\dagger}$ Clay, silt, and sand values are a percentage by weight of $50 \mathrm{~g}$ soil samples with gravel removed prior to analysis. 
Table 23. Summary of Dominant Species \% Quadrat Cover vs Environmental Variable Single Linear Regressions, Part 3 of 4

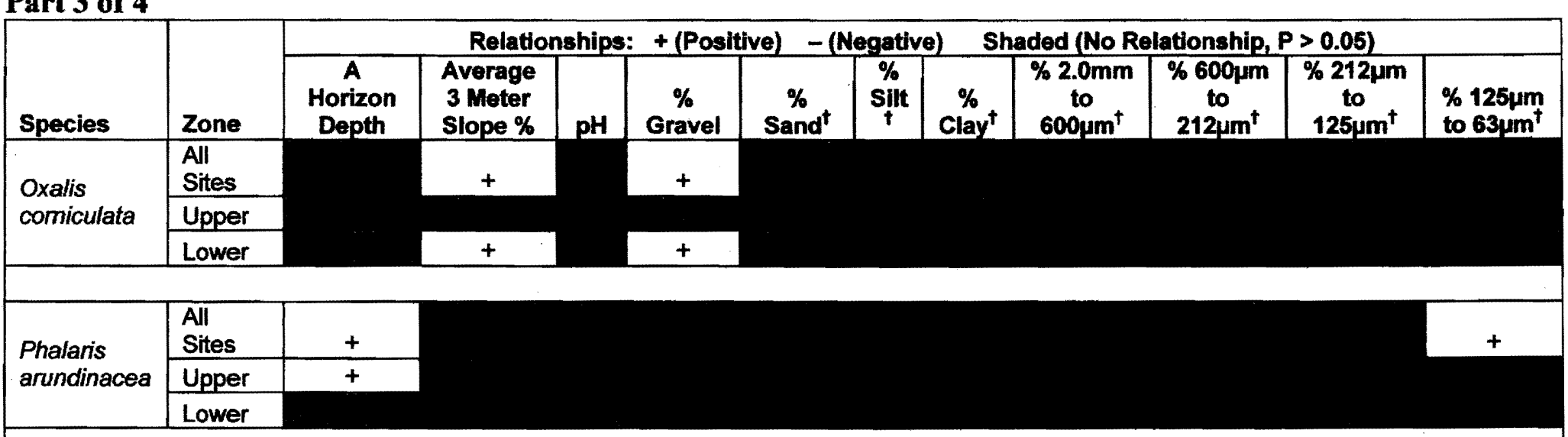

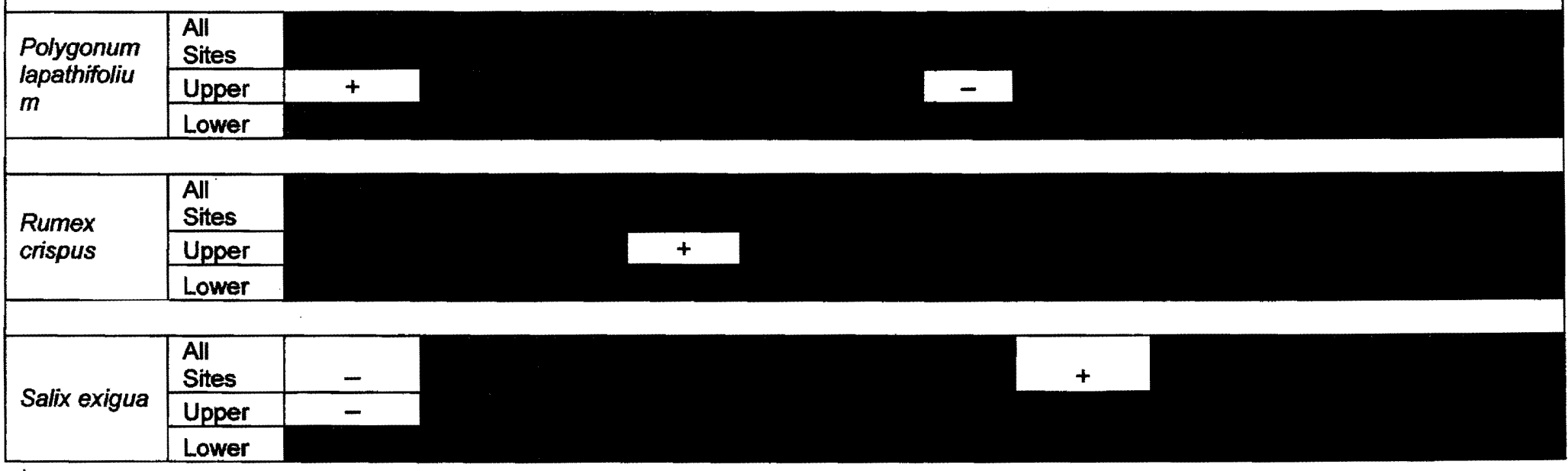

${ }^{t}$ Clay, silt, and sand values are a percentage by weight of $50 \mathrm{~g}$ soil samples with gravel removed prior to analysis. 
Table 24. Summary of Dominant Species \% Quadrat Cover vs Environmental Variable Single Linear Regressions, Part 4 of 4

\begin{tabular}{|c|c|c|c|c|c|c|c|c|c|c|c|c|}
\hline \multirow[b]{2}{*}{ Species } & \multirow[b]{2}{*}{ Zone } & \multicolumn{6}{|c|}{ Relationships: + (Positive) } & \multicolumn{5}{|c|}{ Shaded (No Relationship, $P>0.05$ ) } \\
\hline & & $\begin{array}{l}\text { A } \\
\text { Horizon } \\
\text { Depth }\end{array}$ & $\begin{array}{l}\text { Average } \\
3 \text { Meter } \\
\text { Slope \% }\end{array}$ & pH & $\begin{array}{c}\% \\
\text { Gravel }\end{array}$ & $\stackrel{\%}{\text { Sand }}$ & $\begin{array}{c}\% \\
\text { silt }\end{array}$ & Clay $^{\%}$ & $\begin{array}{c}\% 2.0 \mathrm{~mm} \\
\text { to } \\
600 \mu \mathrm{m}^{*}\end{array}$ & $\begin{array}{c}\% 600 \mu \mathrm{m} \\
\text { to } \\
212 \mu \mathrm{m}^{*}\end{array}$ & $\begin{array}{c}\% 212 \mu \mathrm{m} \\
\text { to } \\
125 \mathrm{~mm}^{\ddagger}\end{array}$ & $\begin{array}{c}\% \\
125 \mu \mathrm{m} \\
\text { to } 63 \mathrm{um}^{\ddagger}\end{array}$ \\
\hline \multirow{3}{*}{$\begin{array}{l}\text { Scirpus } \\
\text { americana }\end{array}$} & $\begin{array}{l}\text { All } \\
\text { Sites }\end{array}$ & - & & & & & & & & & & \\
\hline & Upper & & & & & & & & & & & \\
\hline & Lower & & & & & & & & & & & \\
\hline \multirow{3}{*}{$\begin{array}{l}\text { Solidago } \\
\text { occidentalis }\end{array}$} & $\begin{array}{l}\text { All } \\
\text { Sites }\end{array}$ & & + & & & - & + & + & & - & & \\
\hline & Upper & & + & & + & & & & + & & & \\
\hline & Lower & & & & & - & + & + & & - & & \\
\hline \multirow{3}{*}{$\begin{array}{l}\text { Xanthium } \\
\text { strumarium }\end{array}$} & $\begin{array}{l}\text { All } \\
\text { Sites }\end{array}$ & + & + & & & & & & - & + & & \\
\hline & Upper & & & & & & & & & & & \\
\hline & Lower & + & & - & & & & & - & + & & - \\
\hline
\end{tabular}

${ }^{\dagger}$ Clay, silt, and sand values are a percentage by weight of $50 \mathrm{~g}$ soil samples with gravel removed prior to analysis. 
Table 25. Summary of Wetland Indicator Status Group \% Quadrat Cover vs. Environmental Variable Single Linear Regressions

\begin{tabular}{|c|c|c|c|c|c|c|c|c|c|c|c|c|}
\hline \multirow[b]{2}{*}{ Species } & \multirow[b]{2}{*}{ Zone } & \multicolumn{11}{|c|}{ Relationships: + (Positive) - (Negative) } \\
\hline & & $\begin{array}{c}\text { A } \\
\text { Horizon } \\
\text { Depth }\end{array}$ & $\begin{array}{c}\text { Average } 3 \\
\text { Meter } \\
\text { Slope \% }\end{array}$ & pH & $\begin{array}{c}\% \\
\text { Gravel }\end{array}$ & $\begin{array}{c}\% \\
\text { Sand }\end{array}$ & $\begin{array}{l}\% \\
\text { Silt }^{t}\end{array}$ & $\mathrm{Clay}^{\%}$ & $\begin{array}{c}\% 2.0 \mathrm{~mm} \\
\text { to } \\
600 \mathrm{~mm}^{\dagger}\end{array}$ & $\begin{array}{c}\% 600 \mu m \\
\text { to } \\
212 \mu m^{\dagger}\end{array}$ & $\begin{array}{c}\% 212 \mu \mathrm{m} \\
\text { to } \\
125 \mathrm{~m}^{\dagger}\end{array}$ & $\begin{array}{l}\% 125 \mu m \\
\text { to } 63 \mu m^{\dagger}\end{array}$ \\
\hline & All Sites & - & 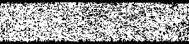 & 2 & 30130 & 3) & Pity & 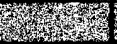 & (2) & $204253=$ & Dins & - \\
\hline \multirow[t]{4}{*}{$\% \mathrm{OBL}$} & Upper & 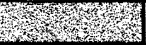 & - & X & 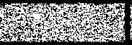 & 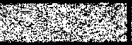 & 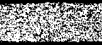 & 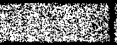 & - & 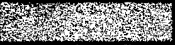 & 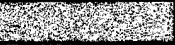 & 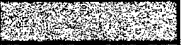 \\
\hline & Lower & (5) & $\sqrt{4}+4$ & (5) & (3) & 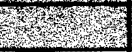 & 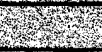 & + & 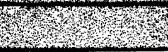 & $x^{2}$ & $8 x^{2}$ & (3) \\
\hline & & & & & & & & & & & & \\
\hline & All Sites & + & W. & 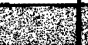 & When & (5) & & (2) & 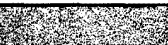 & 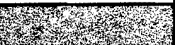 & + & (2) \\
\hline \multirow[t]{4}{*}{$\%$ FACW } & Upper & + & $173^{2}$ & 2. & $y^{2}+2 x$ & 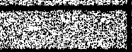 & 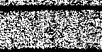 & S. & Pr & 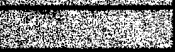 & 2) & 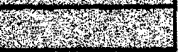 \\
\hline & Lower & S & 54 & 5 & 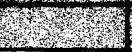 & 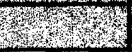 & 20 & Ty & 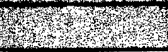 & 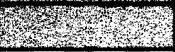 & + & (n) \\
\hline & & & & & & & & & & & & \\
\hline & All Sites & (2) & 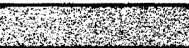 & 25 & 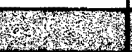 & (25) & & 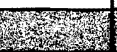 & 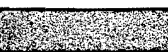 & 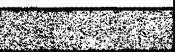 & 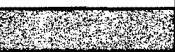 & \\
\hline \multirow[t]{4}{*}{$\% \mathrm{FAC}$} & Upper & Fertryt & $3 \times 14$ & & 8 & 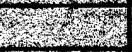 & & 3.4 & $\gamma(x+6)$ & V) & (2) & 2 \\
\hline & Lower & (2) & 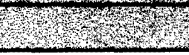 & rir & 378 & $x^{2}$ & & (2) & 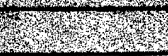 & 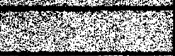 & retrin & $y^{2}$ \\
\hline & & & & & & & & & & & & \\
\hline & All Sites & (2. & + & (5) & + & 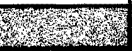 & (3) & $x^{2}$ & & 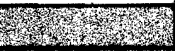 & 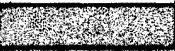 & P. \\
\hline \multirow[t]{4}{*}{$\%$ FACU } & Upper & 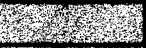 & 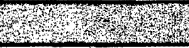 & 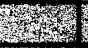 & 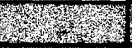 & 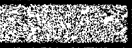 & 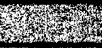 & 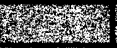 & (1) & 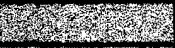 & 3revery & St \\
\hline & Lower & 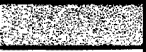 & + & 25 & 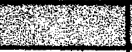 & F & (3) & 3rt? & 4 & $x^{2}$ & 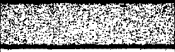 & 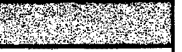 \\
\hline & & & & & & & & & & & & \\
\hline & All Sites & 3 & 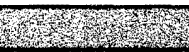 & 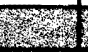 & 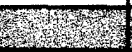 & 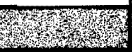 & (5) & & 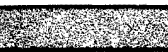 & + & $37 x^{2}$ & - \\
\hline \multirow[t]{2}{*}{ \%UPL } & Upper & & $v^{2}+x^{2}$ & & 2. & S & 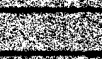 & rxt & & 7. & $x^{2}$ & res \\
\hline & Lower & 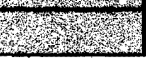 & $x^{2}$ & & 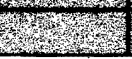 & Whes & & & & 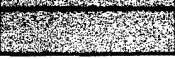 & $x^{2}$ & \\
\hline
\end{tabular}

\footnotetext{
${ }^{\dagger}$ Clay, silt, and sand values are a percentage by weight of $50 \mathrm{~g}$ soil samples with gravel removed prior to analysis.
} 
Examining relationships within the individual zones effectively controlled for flood duration and allowed analysis of finer scale relationships within those zones. Relationships identified by the riparian wide analyses support previous studies and common management approaches that assume that relationships between plants and environmental variables are consistent throughout the riparian zone, and were not subjected to further analysis. Table 26 , Table 27 and Table 28 summarize the relationships that single linear regression identified as significant in only either the , upper or the lower riparian zone. Each of these relationships was further analyzed using Cook's D to determine if individual data points were influential enough to potentially cause the regressions to falsely identify non-significant relationships as significant. This subset of relationships was subjected to diagnostic analyses because the sample size for each was 30 (compared to 60 for the riparian wide analyses), and therefore potentially influenced by individual data points. It was necessary to test for such points in this subset prior to suggesting that the riparian wide analyses were not sensitive to fine scale relationships existing in only one zone of the riparian landscape. Cook's D identified influential data points for five of the relationships, summarized in Table 29.

When the individual influential data points were removed and the single linear regressions run with the remaining data, only one of the above relationships was still found to be significant: Leersia oryzoides vs. A horizon depth. Table 30 summarizes the adjusted set of significant relationships identified in only the upper or lower zone, 
Table 26. Relationships Identified Only in Upper Riparian Zone

\begin{tabular}{|l|l|l|l|l|}
\hline $\begin{array}{l}\text { Environmental } \\
\text { Variable }\end{array}$ & Species & $\begin{array}{l}\text { Species Wetland } \\
\text { Indicator Status }\end{array}$ & Relationship & $\begin{array}{l}\text { Adjusted } \\
\mathbf{R}^{2}\end{array}$ \\
\hline$\%$ Gravel & Rumex crispus & FAC & + & 0.160 \\
\hline$\%$ Gravel & Solidago occidentalis & FACW & + & 0.360 \\
\hline $\begin{array}{l}\% 2.0 \mathrm{~mm} \text { to } \\
600 \mu \mathrm{m}\end{array}$ & Solidago occidentalis & FACW & + & 0.329 \\
\hline$\%$ Clay & Equisetum arvense & FAC & + & 0.156 \\
\hline$\%$ Clay & $\begin{array}{l}\text { Polygonum } \\
\text { lapathifolium }\end{array}$ & FACW & - & 0.100 \\
\hline Depth to C & $\begin{array}{l}\text { Polygonum } \\
\text { lapathifolium }\end{array}$ & FACW & + & 0.201 \\
\hline Avg 3m Slope & Equisetum arvense & FAC & - & 0.165 \\
\hline
\end{tabular}

Table 27. Relationships Identified Only in Lower Riparian Zone

\begin{tabular}{|c|c|c|c|c|}
\hline $\begin{array}{l}\text { Environmental } \\
\text { Variable }\end{array}$ & Species & $\begin{array}{l}\text { Species Wetland } \\
\text { Indicator Status }\end{array}$ & Relationship & $\begin{array}{l}\text { Adjusted } \\
\mathbf{R}^{2}\end{array}$ \\
\hline $\begin{array}{l}\% 600 \mu \mathrm{m} \text { to } \\
212 \mu \mathrm{m}\end{array}$ & Equisetum arvense & FAC & 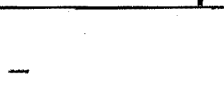 & 0.099 \\
\hline$\% 125 \mu \mathrm{m}$ to $63 \mu \mathrm{m}$ & Equisetum arvense & FAC & + & 0.119 \\
\hline$\% 125 \mu \mathrm{m}$ to $63 \mu \mathrm{m}$ & $\begin{array}{l}\text { Xanthium } \\
\text { strumarium }\end{array}$ & FAC & - & 0.135 \\
\hline Depth to C & Euphorbia supina & UPL & + & 0.186 \\
\hline Depth to C & Leersia oryzoides & $\mathrm{OBL}$ & + & 0.196 \\
\hline Depth to C & Mollugo verticillata & FAC & + & 0.132 \\
\hline $\mathrm{pH}$ & $\begin{array}{l}\text { Xanthium } \\
\text { strumarium }\end{array}$ & FAC & - & 0.140 \\
\hline
\end{tabular}

Table 28. Wetland Indicator Status Group Relationships Identified in Only One Zone

\begin{tabular}{|l|l|l|l|l|}
\hline $\begin{array}{l}\text { Environmental } \\
\text { Variable }\end{array}$ & $\begin{array}{l}\text { Wetland Indicator } \\
\text { Status }\end{array}$ & Zone & Relationship & Adjusted $\mathbf{R}^{2}$ \\
\hline Average Slope \% & OBL & Upper & - & 0.120 \\
\hline$\%$ Clay & OBL & Lower & + & 0.167 \\
\hline
\end{tabular}

Table 29. Relationships with influential points identified by Cook's D

\begin{tabular}{|l|l|l|c|}
\hline Species & Environmental Variable & Zone & $\begin{array}{l}\text { Number of } \\
\text { influential points }\end{array}$ \\
\hline Rumex crispus & $\%$ Gravel & Upper & 2 \\
\hline Equisetum arvense & $\%$ Clay & Upper & 1 \\
\hline Equisetum arvense & Average 3m Slope & Upper & 1 \\
\hline Leersia oryzoides & A Horizon Depth & Lower & 1 \\
\hline Mullugo verticillata & A Horizon Depth & Lower & 1 \\
\hline
\end{tabular}


and verified with the Cook's D analysis. Normal Q-Q plots, showing standardized residual vs. theoretical quantiles for the relationships in Table 30 (including Leersia oryzoides vs. A horizon depth with the outlier identified by Cook's D removed) are presented in Table B-1 through Table B-12 in Appendix B.

The binary logistic regressions performed identified only one instance in which the environmental variable predicted the presence or absence of the species. A horizon depth in the upper zone has a positive relationship with (predicts) the presence of $P$. lapathifolium, with a $\mathrm{P}$ value of 0.029 . The $\mathrm{P}$ value of the subsequent logistic regression performed on the quadrat cover data using only sites with non-zero values was 0.188 , indicating that the remaining data did not fit the Poisson distribution. 
Table 30. Summary of Verified Significant Relationships Identified in Only One Zone

\begin{tabular}{|l|l|c|c|c|}
\hline $\begin{array}{c}\text { Environmental } \\
\text { Variable }\end{array}$ & \multicolumn{1}{|c|}{ Species } & $\begin{array}{c}\text { Species } \\
\text { Wetland } \\
\text { Indicator } \\
\text { Status }\end{array}$ & Relationship & $\begin{array}{c}\text { Adjusted } \\
\mathbf{R}^{2}\end{array}$ \\
\hline$\%$ Gravel & Solidago occidentalis & FACW & + & 0.360 \\
\hline $\begin{array}{l}\% 2.0 \mathrm{~mm} \text { to } \\
600 \mu \mathrm{m}\end{array}$ & Solidago occidentalis & FACW & + & 0.329 \\
\hline$\%$ Clay & $\begin{array}{l}\text { Polygonum } \\
\text { lapathifolium }\end{array}$ & FACW & - & 0.100 \\
\hline Depth to C & $\begin{array}{l}\text { Polygonum } \\
\text { lapathifolium }\end{array}$ & FACW & + & 0.201 \\
\hline
\end{tabular}

Relationships Identified Only in Lower Riparian Zone

\begin{tabular}{|c|c|c|c|c|}
\hline $\begin{array}{c}\text { Environmental } \\
\text { Variable }\end{array}$ & Species & $\begin{array}{l}\text { Species } \\
\text { Wetland } \\
\text { Indicator } \\
\text { Status }\end{array}$ & Relationship & $\begin{array}{c}\text { Adjusted } \\
\mathbf{R}^{2}\end{array}$ \\
\hline $\begin{array}{l}\% 600 \mu \mathrm{m} \text { to } \\
212 \mu \mathrm{m}\end{array}$ & Equisetum arvense & FAC & - & 0.099 \\
\hline$\% 125 \mu \mathrm{m}$ to $63 \mu \mathrm{m}$ & Equisetum arvense & FAC & + & 0.119 \\
\hline$\% 125 \mu \mathrm{m}$ to $63 \mu \mathrm{m}$ & Xanthium strumarium & FAC & - & 0.135 \\
\hline Depth to C & Euphorbia supina & UPL & + & 0.186 \\
\hline $\mathrm{pH}$ & Xanthium strumarium & FAC & - & 0.140 \\
\hline
\end{tabular}

Wetland Indicator Status Relationships Identified in Only One Zone

\begin{tabular}{|l|c|c|c|r|}
\hline $\begin{array}{c}\text { Environmental } \\
\text { Variable }\end{array}$ & $\begin{array}{c}\text { Wetland Indicator } \\
\text { Status }\end{array}$ & Zone & Relationship & $\begin{array}{c}\text { Adjusted } \\
\mathbf{R}^{2}\end{array}$ \\
\hline Average Slope \% & OBL & Upper & - & 0.12 \\
\hline$\%$ Clay & OBL & Lower & + & 0.167 \\
\hline
\end{tabular}




\section{DISCUSSION}

\section{Vegetation Observations}

The proposed upper and lower zones of the annually inundated floodplain have different vegetation characteristics from each other. Both zones have a similar number of total species (25 in the upper and 27 in the lower zone). However, distinct differences in the distribution of riparian cover by species was apparent between zones. In the upper zone, two species (Phalaris arundinacea and Xanthium strumarium) account for $53.17 \%$ of the total cover. Percentage of vegetation cover in the lower zone is more evenly distributed across more species. The two most dominant species in the lower zone (Xanthium strumarium and Equisetum arvense) account for $29.92 \%$ of lower riparian vegetation cover. Two other species, Carex aquatilis and Equisetum arvense each account for more than $10 \%$ of lower riparian cover, while the remaining 23 species each account for less than $10 \%$ of lower riparian cover (Table 4). Important to this study is the fact that when the annually flooded riparian zone is viewed as a single unit, $P$. arundinacea is the second most dominant species, accounting for $15.59 \%$ of the riparian vegetation cover. However, when the lower

zone is examined alone, this plant is a relatively minor component, ranked number 10 , accounting for only $4.09 \%$ of total plant cover. $P$. arundinacea accounts for such a high percentage of vegetation cover in the entire riparian zone because in the upper zone it accounts for $27.78 \%$ of total vegetation cover. This is the first of numerous 
examples of potentially important fine-scale spatial vegetation cover characteristics that are lost when the riparian zone is studied as a single zone.

$X$. strumarium is ubiquitous across the studied riparian landscape. It is the most dominant species for the entire riparian zone (20.54\% of vegetation cover) and lower riparian zone ( $15.96 \%$ of vegetation cover), and second most dominant in the upper zone $(25.39 \%$ of vegetation cover). However the apparent similarities are somewhat misleading, as vegetation cover is more evenly distributed among more species in the lower zone. Unlike in the upper zone, the percent of total vegetation cover attributed to $X$. strumarium in the lower zone is barely more than the next three most dominant species. The relative importance of $X$. strumarium at the riparian scale is skewed considerably by its disproportionately high percentage of vegetation cover in the upper zone.

Scirpus americanus and Carex aquatilis are both rather important species in the lower zone. S. americanus accounts for $11.14 \%$ of total lower riparian vegetation cover and $4.21 \%$ of total upper riparian vegetation cover. The relative cover for $C$. aquatilis is similarly divergent, at $11.28 \%$ of total lower riparian vegetation cover and $3.88 \%$ of total upper riparian vegetation cover. When the entire riparian zone is averaged $(S$. americanus $=7.77 \%$ and $C$. aquatilis $=7.69 \%$ of total riparian vegetation cover), the relative importance of these plants is understated for the lower zone, and overstated for the upper zone. This is particularly apparent for C. aquatilis, which is the third most dominant species in the lower zone, and the eighth most in the upper zone. 
Kalliola and Puhakka (1988), Hupp and Osterkamp (1996), and Hughes (1997) found that floodplain plant species respond to a variety of abiotic factors, and that portions of the floodplain subjected to more flooding develop more variable surface topography. Wintle and Kirkpatrick (2007) demonstrated that riparian species richness is higher in locations with increased scour. The results of my study support these concepts, as the lower floodplain, exposed to longer, more frequent, and more powerful flooding, features a more heterogeneous physical environment and a more heterogeneous plant community than the upper riparian zone. The marked difference in vegetation cover, with the upper zone dominated by relatively few species, likely hampers the ability of the riparian-wide vegetation analysis to recognize important fine spatial scale vegetation patterns that are apparent in the lower riparian zone.

Both zones have similar combined percentages of total vegetation cover by OBL, FACW, and FAC species combined $(96.54 \%$ and $96.28 \%$ in the upper and lower zones, respectively), as well as mean percent of quadrat cover by these species combined (110.6\% and $113.1 \%$ in the upper and lower zones, respectively). Both zones qualify for wetland status based on plant cover. However, the distribution of cover by OBL, FACW and FACU species as individual groups shows distinct differences, while the percent of vegetation and quadrat cover by FAC species is similar in both zones.

Not surprisingly, the upper zone, subjected to shorter flood durations and closer to upland seed sources, contains five FACU species, compared to three FACU species in the lower zone. Percent of vegetation cover by these species is similar at 
$2.42 \%$ in the upper and $2.11 \%$ in the lower zone. The upper zone has greater FACU species diversity, despite similar vegetation cover percentages. Table A-20, in Appendix A, shows that while there are no significant relationships between aggregated FACU species in the upper zone, there is a significant positive relationship in the lower zone with slope. With extended flooding in the lower zone, FACU species may be relegated to sites with physical features, such as increased slope, that promote drier soil (Nassif and Wilson 1975, Dingman 2002). It is also possible that some of the FACU species found in this riparian zone are more or less tolerant to other factors related to flooding, such as scour. In such cases, the more sensitive species may succeed in the upper zone, but not in the lower zone.

Percent of vegetation cover by OBL species in the lower zone is $43.05 \%$, compared to $19.62 \%$ in the upper zone. Mean percent of quadrat cover is $50.9 \%$ in the lower zone and $19.6 \%$ in the upper zone. This substantial difference reflects the adaptations of OBL species to longer flood durations, greater scour, and increased erosion and deposition in the lower zone. Additionally, the percentages of both total vegetation cover and of mean quadrat cover for FAC, FACU, and UPL species are quite similar between the two zones. The major differences in cover at the zone or quadrat scale are between $\mathrm{OBL}$ and FACW species. $P$. arundinacea, a FACW species, singularly is so dominant in the upper zone that it accounts for a substantial portion of the disparity between zones for wetland indicator status groups. FACW species account for $37.5 \%$ of vegetation cover and have a mean quadrat cover of $44.2 \%$ in the upper zone. In the lower zone these species account for $14.4 \%$ of vegetation cover and 
have a mean quadrat cover of $17.9 \%$. In addition to the effects of $P$. arundinacea dominance, this reflects the ability of FACW plants to out-compete OBL plants at slightly drier locations (Smith et al 1999, Boudell and Stromberg 2008).

Despite highly similar percent of vegetation and mean quadrat cover by $\mathrm{OBL}$; FACW, and FAC species combined, the lower riparian zone contain more species of each of these wetland indicator statuses. More OBL species in the lower zone may simply be a function of the extended flooding, making a few species with higher water demands and greater flood tolerance able to out-compete FACW and FAC plants only in the lower zone. The lower zone notably contains one more FACW plant species than the upper zone, despite FACW plants accounting for significantly more percentage of vegetation and mean quadrat cover in the upper zone than in the lower zone. Part of this difference is driven by the upper riparian abundance of $P$. arundinacea, as discussed previously. The greater disturbance and creation of more microsites in the lower zone also increases the diversity of species relative to the upper zone (Kalliola and Puhakka 1988, Wintle and Kirkpatrick 2007). FAC cover in both zones is very similar, yet there are nine FAC species in the lower zone, and only seven in the upper zone. The abundance and diversity of FAC species is facilitated by the arid climate of the John Day River region. When annual floods or storm-related flood pulses recede, there is increased soil evaporation. Patches of soil with lesser water retention capacities will dry out relatively quickly (particularly in this semi-arid region), creating sites that are hospitable to less flood tolerant plants (Smith et al. 1998). 
There are nine species in the lower zone that are not in the upper zone, and seven in the upper zone that are not in the lower zone. Eight of the lower zone species not found in the upper zone are OBL, FACW, and FAC. Only three of the species found in the upper zone but not the lower zone fit these categories. It is possible that throughout the summer the relative cover by various species could shift as drought tolerant plants increase in size and plants with higher water demands either stop growing or die back. This could affect the comparisons between the upper and lower zones. However, this effect was minimized by the study implementation, including beginning sampling in each zone immediately after the floods receded from that zone.

The broader range in $\mathrm{OBL}, \mathrm{FACW}$, and $\mathrm{FAC}$ species diversity in the lower zone is likely influenced by a variety of factors, including biotic factors. For example, $P$. arundinacea forms dense monotypic stands, that once established can out-compete existing vegetation, as well as prevent propagules of other plants from becoming established at a site. Abiotic factors are also important. The lower zone is subjected to more flooding disturbance, and a greater range of disturbance types. Scour, deposition, sediment-plant and sediment-floodplain geomorphology dynamics create a physically heterogeneous landscape in floodplains (Kalliola and Puhakka 1988, Hughes 1997, Walling and He 1997, Smith et al. 1998). This is evidenced by the greater ranges of percent gravel, sand, and silt in the lower riparian zone than in the upper zone.

Flood disturbance is more dramatic more often in the lower riparian zone, creating a more complex physical environment, with more patchiness and variety of microsites. This affects subsequent stream power, soil drainage and evaporation, and 
other factors that affect plants (Kalliola and Puhakka 1988, Hughes 1997). The dry local climate increases evaporation in even the lower riparian sites (Patten 1998, Smith et al. 1998). This external environmental pressure on microsites enhances the patchiness of water availability. The resultant increased heterogeneity of the lower riparian physical environment allows the establishment of a wider range of species and the success of a wider range of life histories than in less complex landscapes like the upper riparian zone.

\section{Hypothesis Testing}

\section{Hol: There is no difference in herbaceous and woody sapling plant composition} between the upper and lower floodplain.

My first hypothesis was that herbaceous and woody sapling plant composition would not differ significantly between the proposed upper and lower riparian zones. If the riparian zone functions as a single unit from the edge of a stream at baseflow to the upper extent of regular flooding, then random sampling should have identified no difference in the occurrence and cover by individual species and species groups (such as wetland indicator status) based on distance from the stream within that unit.

Of 34 species found in the study area, 18 are considered dominant (more than $1 \%$ of total cover and encountered in at least three quadrats), and eight of these differ significantly between the upper and lower riparian zones, in terms of percentage of quadrat cover. Of the dominant species that are significantly different between zones, $P$. arundinacea exhibits greater quadrat cover in the upper zone, and Rumex crispus 
occurrs only in the upper zone. Carex aquatilis, Euphorbia supina, Leersia oryzoides, Mentha arvensis, and Scirpus americanus has higher quadrat cover in the lower zone. Cyperus aristatus occurrs only in the lower zone.

The species with higher cover in the upper zone include one FACW species and one FAC species. Species with significantly greater cover in the lower zone include four OBL species, one FACW species, and one UPL species. OBL species account for significantly more quadrat cover in the lower zone than the upper zone, while FACW species account for significantly more quadrat cover in the upper zone than the lower zone. It is not surprising that all of the OBL species with significantly different coverage between zones are more abundant in the lower zone. OBL species as a group possess numerous adaptations to survive and reproduce under oxygen stress from inundation, as well as the physical processes of scour, sedimentation, and stream power that are associated with flooding. (Guard 1995, Bendix 1999, Mitsch and Gosselink 2000, Karrenberg et al. 2002). These conditions might kill, damage, or remove less flood-tolerant species, allowing less competition for colonization by the OBL species, as well as promote vegetative reproduction by OBL species (Bendix 1999). While this is likely the case at some points in space, the generally similar cover by FAC species across the riparian zone indicates that conditions are not entirely inhospitable to less adapted species in the lower zone. OBL species may simply outcompete less adapted species at many of these sites. That the lower zone also has significantly more quadrat cover than the upper zone by a single UPL species likely reflects the greater heterogeneity of the physical landscape of the lower riparian zone, 
which provides sites suitable for colonization by UPL species adjacent to sites suitable for OBL species colonization.

On a species-by-species basis, the hypothesis testing performed rejected the null hypothesis roughly one quarter of the time for all species, and just under half of the time for the dominant species. Species that differ significantly between zones account for $38.86 \%$ of total cover in the upper zone and $35.72 \%$ of total cover in the lower zone. This alone does not determine whether the plant communities in the two zones are significantly different from each other.

The ANOSIM analysis considers differences in quadrat cover by species between the zones, regardless of whether the values are statistically different. The aggregate differences between the upper and lower zones based on percent quadrat cover by all species resulted in rejection of the ANOSIM null hypothesis. According to this multi-species, multivariate approach, the upper and lower riparian zones constitute two unique, statistically dissimilar plant communities. The results of physical environmental variable hypothesis testing and of the regressions performed help explain why the two distinct plant communities exist in the floodplain.

These findings are consistent with a number of previously published studies. The growing conditions available to plants do differ based on position within the floodplain (Harris 1987, Hughes 1997, Dwire et al. 2004). The area adjacent to the baseflow stream is subjected to more flooding throughout the year than the area immediately down slope from bankfull conditions. This results in coarse scale differences in hydrology that affect plants (Hughes 1997, Smith et al. 1998). The 
dynamics between stream flow, sediment, vegetation, and geomorphology create a mosaic of physical environmental conditions that also affect plants on a fine scale, and position within the floodplain has been shown to influence these patterns (Harris 1987, Kalliola and Puhakka 1988, Hughes-1997, Stromberg et al. 1997).

\section{Ho2: There is no difference in depth of the A horizon, local surface slope gradient,} soil pH, and soil texture, between the upper and lower floodplain.

My second hypothesis was that the two proposed zones would not differ significantly in terms of four selected physical environmental variables. The null hypotheses were accepted for surface slope gradient and soil $\mathrm{pH}$. Slope angle is largely controlled by underlying geology, soil stability, climate, and weathering. These factors may vary widely in a drainage as large and diverse as that of the John Day River, but such variations exist on a scale considerably greater than the floodplain scale. Random samples from the upper and lower floodplain captured a range of slope gradients from $5 \%$ to $44 \%$. Any two points compared between the upper and lower zones may have dramatically different slope angles, but across the sample sets, the coarse-scale controls on slope are reflected by statistically similar values between zones.

Soil $\mathrm{pH}$ is controlled primarily by parent material, biological inputs and process, and weathering (Gerrard 2000). Each of these features varies considerably throughout the drainage. This is reflected in the range of $\mathrm{pH}$ from 5.2 to 7.5. The processes of sediment transport, erosion, and deposition that regularly occur in 
riparian zones create a mosaic of soils with different properties, including $\mathrm{pH}$, that are reflected by the variation of individual sample points. However, across the entire dataset, the large-scale control over these processes and the resulting $\mathrm{pH}$ result in no overall difference between the two zones. The generally acidic soil is no surprise, considering the long-term, repeated effects of leaching of cations and their replacement with hydrogen ions, due to flooding (Gerrard 2000). The sandy, frequently disturbed soils encountered within this riparian zone have relatively low organic carbon content; therefore it is unlikely that organic matter decomposition within the soils contributes greatly to the overall acidity. For both slope gradient and $\mathrm{pH}$, the processes that affect the upper zone are similar or identical to those that affect the lower zone (Chambers et al. 1999).

The null hypothesis was rejected for depth of the A horizon. At each of the study locations, the depth of the A horizon is equal to the depth to the $\mathrm{C}$ horizon. It appears that a combination of the generally sandy soil with the regular erosion and deposition process disrupts the soil forming processes enough that diagnostic horizons have not developed in this part of the floodplain. Mitsch and Gosselink (2000) point out that this is a common feature of riparian wetland soils. The statistically significant differences in the depth of the A horizon are primarily attributable to the stream power associated with proximity to or distance from the stream channel. The depth of the lower zone A horizon tends to be much less than that of the upper zone. This zone is subjected to stronger flows, greater scour and erosion, and less deposition. A study of floodplain sedimentation conducted by Asselman and Middelkoop (1995) 
demonstrated that deposition rates on the banks of levees averaged $4 \mathrm{~kg}$ per square meter, while in the low lying areas, the average rate was $1.6 \mathrm{~kg}$ per square meter.

The range of A horizon depths is greatest in the upper zone. Numerous studies have demonstrated that, other factors being equal, sediment deposition decreases with distance from the channel (Asselman and Middelkoop 1995, Walling and He 1997). In addition, Asselman and Middlekoop (1995) also demonstrated greater sedimentation rates on levee banks compared to low lying areas. On the John Day River, floodplain width is quite variable. Where floodplain slope is steeper, the lateral extent of flooding is diminished. I performed a series of regression analyses and determined that in the upper floodplain, slope and A horizon depth have a relatively strong significant positive relationship $\left(\mathrm{P}=0.003\right.$, Adjusted $\left.\mathrm{R}^{2}=0.255\right)$. This indicates that on this river, sites with steeper slopes in the upper riparian zone demonstrate the increased sedimentation rates associated with levee banks. Upper riparian sites in reaches with low lateral slope gradients are constrained by the depth of floodwater, not by the slope. These upper riparian sites are further from the channel than upper riparian sites in reaches with high lateral slope gradients. These sites are subjected to the lesser sediment deposition rates associated with distance from the channel. This variability in channel morphology likely explains a great deal of the variability in A horizon depth in the upper riparian zone.

The results of soil texture analysis show a significant difference between the two zones across all major variables included (percent gravel, sand, silt, and clay). The patterns displayed are reasonably predictable and are consistent with other studies on 
sedimentation patterns associated with stream flooding within floodplains (Marriott 1992, Walling and He 1997). Gravel and sand percentages are highest in the lower zone, silt and clay percentages are highest in the upper zone. These patterns even extend to the sand fraction of the soil. The lower zone has a statistically greater proportion of $600 \mu \mathrm{m}$ to $212 \mu \mathrm{m}$ sand than the upper zone, and the upper zone has a greater proportion of $125 \mu \mathrm{m}$ to $63 \mu \mathrm{m}$ sand particles than the lower zone. Stream power and water column depth are greater near the active channel, allowing entrainment and transport of larger particle sizes such as sand and gravel. Smaller particles, such as silt and clay remain suspended for longer periods of time in such conditions, and barring overriding channel features such as backwaters or eddies, their deposition rates near the channel are relatively low. As distance from the channel and water column depth decreases, stream power and the total sediment load of the water decrease. Coarser sediments are deposited in the lower zone subjected to higher flow rates, leaving a greater proportion of silt and clay compared to sand available for deposition in the upper zone. As the water slows in the upper floodplain, more of the fine sediments are able to settle out (Marriot 1992, Walling and He 1997)

With the exception of clay, the lower riparian zone shows more variability for percentages of soil texture categories. Within each zone a wide range of features can influence the soil texture: stream power, depth of the water column, vegetation features that slow water or preferentially trap smaller or larger soil particles, and microtopographical features (Hughes 1997, Lowrance and Sheridan 2005, Francis 2006). Therefore the range of within-zone values is not surprising. The greater range 
in the lower zone may be explained by the fact that as a whole, it experiences a greater range of water depth and stream flow power. In an average year, there is a limit to the depth and force of water that affects the upper zone. This results in a constrained range of these environmental variables that influence soil texture in this zone. The lower zone will experience generally deeper water and more powerful flows than the upper zone. However, as the annual flood recedes, the lower zone will be subjected to more moderate values for these variables. Toward the end of flooding the lower zone will be subjected to the same or similar water depth and flow force as the upper zone experienced as a maximum. So the deposition and sorting effects that were active in the upper zone when the lower zone was subjected to much different effects will now influence the lower zone. Ultimately this may result in a greater range of soil texture between sites in the lower zone than between upper zone sites.

The PCA suggested that the studied environmental factors with greatest PC1 eigenvalues within the zones were sand, silt, and clay percentages. Interestingly, the analysis of the entire riparian zone marked percent gravel with the next greatest eigenvalue, while individual zone analyses found that slope gradient had a higher eigenvalue than percent gravel. Slope gradient has the lowest eigenvalue of all factors for PC1 in the total riparian zone. Soil texture is clearly the environmental variable that accounted for the majority of variance within each zone, and the riparian zone in general.

The ANOSIM analysis considers differences in environmental variable values between the zones, regardless of whether the values are statistically different. The 
aggregate differences between the upper and lower zone based on all of the measured variables resulted in the rejecting of the ANOSIM null hypothesis. According to this multivariate approach, the upper and lower riparian zones have two distinct sets of environmental conditions based on those variables measured. Soil texture, depth of the A horizon, the surface slope gradient, and $\mathrm{pH}$ are all factors that can influence a plant species' success at a given location. Because the two zones possess statistically different environmental properties, it is no surprise that they also host statistically different plant communities.

Ho3: There is no difference in relationships between herbaceous and woody sapling plant composition and soil texture, soil pH, local surface slope gradient, and depth to Chorizon, between the upper and lower floodplain.

\section{Overview of Species - Environmental Variable Regression Analysis}

My final null hypothesis was that if a relationship between a plant species or plant group and a physical environmental factor existed in either the upper or lower zone that the same relationship would exist in the other zone. To further examine the issue of the riparian zone as a single unit compared to two different units, I performed regression analyses not only for the upper and lower zones, but also for the entire riparian zone (Table 21 through Table 24). It is important to note that these regressions were performed not to establish causality between environmental variable values and species quadrat cover, but rather to test generally whether riparian-wide analyses are sensitive to significant relationships that may exist in restricted portions of the studied 
riparian zone. An attempt was made to apply readily available research by others to explain possible causes for the significant relationships discussed below.

There are significant plant species-environmental variable relationships at each level of analysis: 29 in the entire riparian zone, 13 in the upper zone and 22 in the lower zone. However, for the total riparian and lower riparian regressions, if sand, silt, or clay percentage has a significant relationship, the other two of these variables always do as well. In such instances, a positive correlation with sand always has a negative correlation with silt and clay and vice-versa. This is not the case in the upper zone, where clay has significant relationships with two species, but sand and silt have no significant species relationships. Sand is a dominant soil component in general, but this is especially true for the lower zone. This is likely reflected by the fact that lower zone relationships with sand are always associated with opposite relationships to silt and clay. Sand is less dominant, and silt and clay show a greater range of values in the upper zone. Therefore clay relationships in the upper zone are not necessarily driven by sand percentages or relationships with sand percentage.

Examining the data at both the riparian-wide and stratified riparian zone scales revealed ecosystem properties that may have implications for future study and management of riparian zones. Results of all significant relationships identified are summarized in Table 21 through Table 24 . There is only one instance in which a relationship is apparent between species quadrat cover and an environmental variable for the upper and lower riparian zones: A horizon depth has a negative relationship 
with Glycyrrhiza lepidota quadrat cover in both zones, and this negative relationship is also displayed in the riparian-wide analysis.

There are five relationships that are apparent for the entire riparian zone and the upper zone, and there are 13 relationships apparent for the entire riparian zone and lower riparian zone. In such cases, the relationships that would be identified with a riparian-wide analysis would overstate the plant-environmental relationships in the zone with no significant relationship. The analysis results identified situations in which the total riparian analysis either overstate or understate relationships that actually exist in one of the two zones $\left(\mathrm{R}^{2}\right.$ value higher for total riparian than for upper or lower riparian or $\mathrm{R}^{2}$ value lower for total riparian than for upper or lower riparian, respectively).

Based on the initial single linear regression analyses, there are seven unique plant-environmental relationships that are apparent only in the upper zone, and seven that are apparent only in the lower zone. Diagnostic regression analysis determined that four of these apparent relationships were due to the presence of influential outliers (three in the upper zone, and one in the lower zone; Table 30). The riparian-wide analysis described in the "Results" section fails to recognize the ten confirmed plantenvironment relationships within the individual zones. This demonstrates the lack of ability for riparian-wide analyses to identify all relationships between species and environmental variables. If the species in question are important from a management perspective (either as desirable or undesirable species), then only the analysis at the 
fine scale would reveal patterns that further understanding of the dynamics in question.

Of the binary logistic regressions performed, only a single relationship was identified for which the environmental relationship was predictive of the presence or absence of the species: increased A horizon depth was significantly related to the presence of Polygonum lapathifolium in the upper zone. Because of the percent quadrat cover methodology, if the species or wetland indicator status group was so much as visibly detectable within a quadrat during the field study, the statistical analysis considered it present, making the analysis sensitive only to the presence of a species, but not to its contribution to riparian or zone cover. Several of the species, including $S$. occidentalis in the upper zone, E. arvense and $X$. strumarium in the lower zone, and OBL species in both zones, are present at most or all sites. To the contrary, $P$ lapathifolium is present at only six sites in the upper zone. Depth of the A horizon was a truly limiting factor for the presence of this species, and the analysis used was able to detect this.

The discussion will now focus on the relationships that were identified for only one zone within the floodplain, but not by the riparian-wide analyses. While the analyses were able to identify the existence and to some degree the nature of these relationships (positive or negative correlation), they did not identify why the relationships exist. This study was intended to establish whether plant-environmental relationships differ between the upper and lower zones, and whether riparian-wide analyses are sensitive to differences that may exist between different zones within the 
floodplain. It was not designed to investigate individual species adaptations to particular environmental conditions; therefore, the following discussion is limited to a broad analysis of the relationships identified in one zone, but not at the riparian-wide scale. Specific species-environmental relationships identified in this study may not apply to other riparian ecosystems with different soil textures, flood regimes or climates, so the discussion of these relationship differences is intended to encourage additional research across a range of riparian systems with the same and with different species.

Individual species-environmental relationships identified only in the upper riparian zone

Seven apparent relationships were identified, and four of these were confirmed by diagnostic regression analyses, in the upper zone only. Table 30 summarizes these relationships. Three of the four confirmed relationships in only the upper zone involve soil texture, while the other one involves depth of the A horizon.

Soil texture affects plants growing in the riparian zone by influencing the permeability and hydrologic conductivity of the soil and the rates of direct evaporation from the soil, which in turn affects the availability of soil water to plants. Soil texture has been demonstrated to be an important factor influencing riparian vegetation through hydrologic control (Chambers et al. 1999, Law et al. 2000, Dong et al. 2003). Solidago occidentalis had significant positive relationships with coarse soil components (percent gravel and coarse sand) in the upper riparian zone only. Coarse 
soil is often more permeable to hydrological inputs, but may also drain more quickly and experience more direct evaporation than fine grained soils (Dingman 2002, Dong et al. 2003). In the upper riparian zone, the influence of drainage and evaporation on soil water availability and resulting effects on plant species may be amplified compared to the lower zone, which receives greater hydrologic inputs. Species with positive relationships to these variables may out-compete other species with higher water demands in this setting.

Percent clay has a significant negative relationship with percent quadrat cover by Polygonum lapathifolium. Soils with higher clay content retain water by retarding both downward drainage and direct evaporation (Dingman 2002, Dong et al. 2003). In the upper riparian zone, with reduced hydrologic inputs, the presence of clay may hold enough water to allow species with higher water demands to persist at such locations. Conversely, high clay content may negatively affect species that have lower tolerance for waterlogged soil (Aringhieri 2006). Higher clay content is highly correlated with total organic carbon and nitrogen mineralization (Bechtold and Naiman 2006). Species with high nutrient demands may benefit from increased clay concentrations, while more opportunistic species may be out-competed on high clay, high nutrient sites that promote vigorous growth in other species.

Depth of the A horizon has a significant positive relationship with $P$. lapathifolium quadrat cover in the upper zone. As noted above, the only significant relationship in which an environmental variable predicted the presence of a species, was A horizon depth for P. lapathifolium. In this riparian zone, the bottom of the A 
horizon was consistently demarcated by a sharp change from generally sandy soils with some silt and clay, to a $\mathrm{C}$ horizon comprised primarily of large cobbles. This $\mathrm{C}$ horizon provides little in the way of nutrients and space for root growth. The downward extent of root extension by the small herbaceous plants studied, such as $P$. lapathifolium is likely limited by the depth to the $\mathrm{C}$ horizon. The positive relationship with the A horizon depth is similarly likely associated with the lack of soil quality associated with the $\mathrm{C}$ horizon.

Individual species-environmental relationships identified only in the lower riparian zone

Seven apparent relationships were identified, and six of these were confirmed as significant by diagnostic regression analyses, in the lower zone only. Table 30 summarizes these relationships.

Three of the six relationships identified only in the lower riparian zone involve soil texture, and each of these is with grades of sand. The percent of soil between $125 \mu \mathrm{m}$ and $63 \mu \mathrm{m}$ has one positive and one negative relationship to species, each of which is a FAC species. E. arvense has a negative relationship with coarse sand, and a positive relationship with fine sand, while the relationship between $X$. strumarium and fine sand is negative. As discussed previously, soil texture, particularly sand content, affects plants largely through hydrological processes. That two FAC species have opposite relationships with fine sand likely illustrates that FAC species have a range of tolerances to soil saturation and soil water availability. 
Depth of the $\mathrm{A} /$ depth to the $\mathrm{C}$ horizon has two significant relationships in the lower riparian zone that are not identified by the riparian-wide analysis. Percent quadrat cover by Euphorbia supina and Leersia oryzoides each has a positive relationship with this environmental variable. Interestingly, these are a UPL species, and an $\mathrm{OBL}$ species, respectively, each with a positive relationship to the same environmental variable. Throughout the riparian zone, depth of the $A /$ depth to the $C$ horizon has more significant relationships with species than any other single environmental variable. The A horizon is significantly shallower overall in the lower zone than in the upper zone. That a UPL and an OBL species have both have a positive relationship with this variable, it is likely that at least one mechanism affecting their success is the depth of high quality soil, which ends abruptly at the $C$ horizon.

\section{Overview of wetland indicator status group - environmental variable relationships}

The percent of quadrat cover attributed to all species within a given wetland indicator status classification was compared to each environmental variable for the total, upper, and lower riparian zones. This provided an opportunity to identify trends across functional groups and possibly identify relationships between a given environmental variable and a group's aggregate adaptations that the variables may affect. However, due to the aggregation of factors, this approach also risked losing important species-specific resolution or suggesting broad relationships that may not exist for individual species. Only 14 significant relationships were identified between 
the studied environmental variables and wetland indicator status groups (Table 25 in "Results" section). Four were identified only at the riparian-wide scale. One was identified for the total and upper riparian zones. Three were identified for the total and lower riparian zones. One was identified for only the upper zone, and one was identified for only the lower zone. A summary of all significant wetland indicator status group-environmental variable relationships is presented in Table 25 , in the "Results" section.

Each group with the exception of FAC displays significant relationships. Numerous relationships between individual FAC species and environmental variables exist. But it is possible that this group represents such a variety of species, each with substantially different wetland adaptations, that when the effects of environment on those adaptations are aggregated, no relationships are apparent. Despite the potential limitations of this approach, management objectives might be effectively facilitated by looking at functional groups rather than individual species. The value of these analyses for FACU and UPL groups is rather suspect, given the infrequent occurrence of species in these groups and subsequently small dataset for use in the regressions.

Wetland indicator status group - environmental variable relationships identified in only the upper or lower riparian zone

Two relationships are apparent at only the fine scale of analysis, both of which were confirmed as significant by diagnostic regression analyses. One relationship 
exists in the upper zone, and one in the lower zone. Both relationships are with the OBL species group. Table 30 summarizes these relationships.

The relationships identified in only one of the two zones, and not identified at the riparian-wide scale likely relate to fine-scale differences in water availability, as the OBL species group contains plants that are found in jurisdictional wetlands $99 \%$ of the time. In the upper riparian zone, quadrat cover by these species has a negative relationship with increasing surface slope gradient. OBL plants in the upper zone theoretically have the same water requirements as OBL plants in the lower zone. However, in the upper zone these plants experience less frequent and shorter floods, and reduced subsequent hydrological inputs compared to the lower zone. Other factors being equal, sites with lesser slope gradients may be inundated slightly longer than those with greater slope gradients. Receding floodwaters and overland flow at locations with a relatively low slope gradient will have a longer residence time, allowing more water to infiltrate into the soil (Dingman 2002). Sites with lesser slope gradients also experience slower soil water movement downslope and downward through the soil column, increasing soil water residence time at that point (Weyman 1973). This increases the opportunity for the soil to become saturated. Conversely, as slope gradient increases, the influence of each of these processes is reduced or may become reversed, and combined result in local soils that have less water available to the plants. OBL species appear to be sensitive to these differences within the upper riparian zone, where hydrologic inputs are reduced. 
The relationship between OBL species quadrat cover and percent of soil that is clay is positive and significant only in the lower riparian zone. It is not surprising that greater clay content, which increases the soil's water holding capacity, has a positive relationship with OBL species. What is somewhat surprising is that this relationship was not evident in the upper riparian zone or in the total riparian zone analysis. This may be due to the generally sandier nature of the lower riparian soils, such that the presence of clay in the lower zone exerts a greater influence over OBL plants compared to the upper zone. While increased clay content increases soil water holding capacity, it can also decrease the permeability and hydrologic conductivity of soil (Gerrard 2000). It is therefore possible that in the upper zone, where hydrologic inputs are small compared to the lower zone, the water retaining properties that clay imparts to soil are less significant than the effect of clay restricting water movement into and through the soil column during and after flood events.

\section{Research and Management Implications}

This study has demonstrated that not only do two distinct physical environmental zones exist within the annually inundated portions of the John Day River floodplain, but also that two unique plant communities occupy those zones. Further analysis has demonstrated that at least certain plant species and functional groups common to both zones have different relationships with physical environmental variables between the two zones. Riparian studies often treat the entire zone of annual flooding as a single unit and assume that while some predictability in 
environmental gradients exists, the dynamics between plants and environmental variables is stable across this landscape (Harris 1987, Stromberg et al. 1997, Castelli et al. 2000, Law et al. 2000, Dwire et al. 2004).

The results of this study suggest that research and management efforts may benefit from more focused examinations of the finer-scale zones to achieve objectives and to understand more accurately the actual functioning of riparian ecosystems. The riparian-wide approach has been demonstrated to potentially misrepresent ecosystem function in three ways: (1) it may fail to identify relationships that only exist in either the upper or lower zone, but that may be rather important in that zone; (2) it may identify relationships that exist in one zone and not the other, thereby falsely suggesting that relationships exist in the zone from which they are absent; and (3) it may identify relationships that exist in one or both zones, but with under- or overestimated relationship strength for one or both zones.

Detailed studies that focus on plants, environmental variables, and their relationships within the stratified zones should be conducted in a variety of riparian zones in a variety of climates, with different species and soil textures. The relationships identified in this study will not necessarily apply to rivers that have major impoundments or other distuptions to natural flood regimes. In wetter climates, the lack of climate pressure on soil hydrology may result in riparian zones that do not vary considerably in terms of vegetation and plant-environmental relationships. The soils in this study area are sandy loam or loamy sand, while many large rivers have riparian soils with high clay content. Riparian zones with radically different soil 
textures, different flood timing, subjected to different climates, or with different watershed geology, would likely exhibit different internal relationships between plants and environmental variables. Additional environmental variables should also be studied to further understand the extent to which internal riparian zone variables and relationships vary. Soil organic carbon content, available soil nitrogen, soil bulk density, soil salinity, and soil redox potential are commonly studies soil characteristics that can affect or be affected by soil hydrology, and that in turn can affect the success of plants at a given site. Other variables that can affect plant distribution and cover, and which could be considered or controlled for in future studies include herbivory, allelopathy, and floodplain geomorphology as it affects flood flow power. Despite the need for considerable additional research, this study has established that there are notable variations within the stratified zones of the annually inundated floodplain of the John Day River, and while the same specific variations may not apply to all riparian zones, it is likely that additional variations would be found. This finding warrants further study to increase the understanding and reduce the introduction of unnecessary uncertainty into studies of riparian ecosystem dynamics in general. Reducing misunderstanding of the detailed functions of the riparian ecosystem can lead to more efficient application of management focus, effort, and resources. For example, an active restoration effort focused on increasing native wetland obligate species that conducted surveys and regression analyses of OBL species and soil texture throughout the riparian zone might overlook the potential value of planting Eleocharis palustris. The $\mathrm{R}^{2}$ for percent $E$. palustris quadrat cover vs. sand at the 
riparian-wide scale is only 0.108 . However, in the lower zone, the $\mathrm{R}^{2}$ for this relationship is 0.338 . If the analysis stopped at the riparian scale, this species may not seem like an obvious candidate for planting. However, focused at a finer scale we see that for the lower zone, sites with low sand percentage are ideal for $E$. palustris, while in the upper zone, there is no relationship. Therefore a decision might be made to plant this species on less sandy (or on more silty) sites in the lower zone, and to focus on other species that have stronger relationships in the upper zone.

Focusing studies on the upper and lower zones of the annually flooded riparian landscape can also help to develop more accurate views of the ecosystems and their management goal needs. This study suggests that management of individual species of concern could benefit from this zonal analysis approach. For example, at the riparian scale, Phalaris arundinacea appears to be a faitly significant component of the total vegetation cover. In reality, it is a minor component of the lower riparian zone, its importance vastly overestimated by the riparian-scale analysis. On the other hand, the coarse-scale survey greatly underestimates its importance in the upper zone, where it is the most dominant species, accounting for over one quarter of the total vegetation cover. Depending on thresholds, a riparian-wide survey could either determine that this is a species that is not a particular detriment to overall plant biodiversity and should not be managed, or that it does inhibit riparian-wide diversity and should be managed throughout the riparian zone. A fine-scale analysis would suggest that natural factors keep $P$, arundinacea in check in the lower zone, but that in the upper 
zone it is truly an invasive species, and that it should be managed in the upper zone only.

The results of the fine-scale analysis conducted in this study demonstrate that Phalaris arundinacea is a very significant plant in the upper zone $(27.78 \%$ of upper riparian vegetation cover) but a relatively minor component of the lower zone $(4.09 \%$ of lower riparian vegetation cover). Control of the highly invasive plant is the subject of many research and management efforts, and while much has been learned, there is still a need to better understand which environmental factors either promote or inhibit its growth (Miller and Zedler 2003, Lavergne and Molofsky 2004). Recent work by Jenkins et al. (2008) has demonstrated that in a lentic wetland ecosystem, restoration of deep flooding (greater than 0.85 meter) results in a decline in first year $P$. arundinacea biomass. The depth and timing of flooding are both important. Spring flooding to depths between 0.5 and 0.85 meter leads to an increase in $P$. arundinacea biomass. During spring the plant is actively growing and shifts nutrients and carbon from the roots to aboveground tissues. In flooded conditions this species experiences greater stem elongation and can produce adventitious roots at the nodes. If the flooding is deep enough, then the plant exhausts carbon and nutrient stores on these aboveground tissues at the expense of root growth. When floodwaters recede, $P$. arundinacea subjected to deeper flooding is not able to form the dense rhizomatous root systems that allow it to form a local monoculture. $P$. arundinacea undergoes substantial depletion of carbohydrate reserves in late May and June, during the maximum growth of aboveground tissues. 
This coincides with the maximum flooding period in the John Day River system. At the gage at Service Creek, $315 \mathrm{cfs}$ (near this study's lower riparian zone) corresponds to a flood stage of about 2.6 feet, while $4620 \mathrm{cfs}$ (at the upper edge of this study's upper riparian zone) corresponds to a flood stage of about 6.1 feet. The lower zone is therefore flooded to a depth of slightly more than one meter during the time when the upper zone is flooded to a much shallower depth. This occurs during the period of maximum $P$. arundinacea aboveground tissue growth and carbohydrate depletion (Decker et al. 1967). The result of this combination of depth and timing of flooding appears to be significant control of $P$. arundinacea biomass by natural hydrology in the lower riparian zone. $P$. arundinacea has positive relationships with A horizon depth in the total and upper riparian zones, and with percent soil between $125 \mu \mathrm{m}$ and $63 \mu \mathrm{m}$ in the total riparian zone. No relationships are evident only in the lower zone. This is likely due to the considerable control over this species exerted by flood hydrology in the lower zone.

Future riparian studies and management activities should consider approaching the riparian zone as two distinct zones at the upper and lower limits of annual flooding, recognizing that there is likely a gradient between the two. Descriptive statistics for at least certain species and for environmental variables are likely to differ between these two portions of the landscape, and relationships between vegetation and the physical environment may also diverge between zones. If baseline conditions and assumptions are established using this fine-scale approach, such endeavors are likely 
to develop a better understanding of actual conditions and to more appropriately and efficiently apply any subsequent efforts and resources. 


\section{SUMMARY AND CONCLUSION}

This study identified two distinct vegetation and environmental variable zones within the riparian zone subjected to annual flooding by the John Day River, The lower riparian zone has a greater diversity of plant species $(27$ species in the lower zone, 25 species in the upper zone), and the total cover by individual species is more evenly distributed among more species in the lower zone than in the upper zone. The two zones have similar total cover and percent quadrat cover by FAC species. However, they differ considerably in terms of cover by OBL species and by FACW species. T-test results show percentage of quadrat cover by OBL and by FACW species to be statistically different between the two zones.

While some individual species are responsible for statistically the same percentage of quadrat cover, eight dominant species differ between the upper and lower riparian zones. The upper zone has statistically greater quadrat cover by Phalaris arundinacea and Rumex crispus. The lower zone has statistically greater quadrat cover by Carex aquatilis, Cyperus aristatus, Euphorbia supina, Leersia oryzoides, Mentha arvensis, and Scirpus americanus. These eight species combined account for $37.24 \%$ of total riparian, $38.86 \%$ of upper riparian, and $35.72 \%$ of lower riparian vegetation cover. ANOSIM analysis results demonstrate that the two zones have unique plant communities based on the aggregate differences in quadrat cover by each dominant species (those that occur in at least 3 individual quadrats and that account for at least one percent of the total vegetation cover within each zone). 
$\mathrm{pH}$ and surface slope gradient, which are controlled by factors at a scale that supersedes internal floodplain processes, do not differ significantly between the two zones. However, the A horizon depth and soil texture vary substantially between the upper and lower zones. Results of multivariate analysis of all studied physical environmental parameters indicate that the two zones have distinct physical environments to which the resident vegetation is subjected.

The upper zone has significantly deeper A horizons than the lower zone. The force of floodwater is dissipated as distance from the channel increases, so the upper zone is generally subjected to less scour and erosion than the lower zone. Deposition rates on the steeper banks, on which many of the upper riparian sites are located, is higher than those on low lying areas.

The soils of this active floodplain display characteristics of early stages of development. There are no secondary or diagnostic horizons, simply A horizons over impenetrable $\mathrm{C}$ horizons comprised of cobbles. This $\mathrm{C}$ horizon features low soil fertility and is provides a poor growing environment for plant roots. The transition between the $\mathrm{A}$ and $\mathrm{C}$ horizons represents a dramatic change in soil quality. With generally deeper A horizons and shorter duration of flooding, the upper zone's soils provide a more extensive zone of high soil quality than those of the lower zone.

Soils in this riparian zone tend to be either sandy loam or loamy sand, without a great deal of gravel overall (Table 15). Upper riparian mean sand content is $72.72 \%$, ranging between $49.58 \%$ and $92.99 \%$. Lower riparian mean sand content is $78.97 \%$, and it ranges between $36.69 \%$ and $95.55 \%$. Upper riparian silt content averages 
$21.46 \%$, with a range between $2.79 \%$ and $43.47 \%$. Lower riparian silt content mean is $15.79 \%$, with a range between $1.57 \%$ and $53.88 \%$. Upper riparian clay content averages $2.43 \%$, ranging from $0.80 \%$ to $5.23 \%$. The lower riparian zone averages $1.93 \%$ clay, with a range of $0.59 \%$ to $4.96 \%$.

Soil texture is significantly different between the zones for each major component of soil particles. Percent gravel and percent sand are greater in the lower zone. This is not surprising, as the larger particles settle more quickly from deep, fastmoving water than do the finer silt and clay. Similarly, fine soil particles remain entrained in floodwaters longer than coarse particles, and are deposited as the water column depth and flow velocity decrease. Water column depth decreases with surface height relative to the stream channel. Steeper floodplain slopes result in decreased water depth closer to the stream channel than locations with more moderate slopes. Flow velocity decreases with distance from the stream channel. Specific locations within the floodplain with moderate slopes moving away from the stream channel have a wider zone of annual flooding than locations with steep floodplain slopes. Flood flow velocities in such wide flood zones decrease as distance from the channel increase. Water column depth decreases as height above the channel increases. Both phenomena result in increased rates of fine particle deposition moving away from the channel (either horizontally or vertically), and moving toward the limit of annual flooding. Thus, the percentages by weight of silt and clay are significantly higher in the upper zone soils. 
Because the lower zone is subjected to a greater range of water depths and flow velocities every season of flooding, it displays a greater range of gravel, sand, and silt percentages than the upper zone. When examining the soil percent by weight of various sand sizes, the coarser particles are a statistically larger component of the soil in the lower zone; the finer particles are a statistically larger component of the upper zone soils.

The soil textures of the zones alone result in drier soils in the lower zone than in the upper zone, as the upper zone has a greater percentage of water holding silt and clay. The generally more coarse-grained soils in the lower zone promote faster drainage of, and greater rates of direct evaporation from the soil. However, the lower zone is also subjected to greater flooding duration, and overall has shallower A horizons, than the upper zone. The likely result of these combined factors is frequently saturated microsites that dry out quickly once hydrologic input events cease. The lower zone is also subjected to a greater range of flood depth and power, and to a greater range of the resulting processes of scour and sedimentation, resulting in a very patchy physical landscape. This combination of factors may largely explain why the lower zone has such a predominance of OBL species cover, in conjunction with a relatively high percentage of FAC species cover. It may also partially explain why, despite similar percentage of cover by FAC species in both zones, the lower zone has more individual FAC species than the upper zone.

Flood duration is the same or very similar for all sites within the lower zone and for all sites within the upper zone. This obvious, large scale hydrological 
difference between zones is almost certain to affect the plants living in each zone (Harris 1987, Bayley 1995, Dwire et al. 2004), which prompted the initial hypothesis that there would be different plant communities in the two zones. After the null hypothesis that there would be no such difference was rejected by a series of tests, the study focused on which additional environmental factors within each of the two zones influenced a plant's success at any given location within each zone. Examining relationships within the individual zones effectively controlled for flood duration and allowed analysis of finer scale relationships within those zones.

This study demonstrated that in addition to different plant communities and environmental characteristics existing between the upper and lower riparian zones, there are clearly some differences in the relationships between plants and environmental variables between the two zones. Several environmental variables are very strongly related to cover for a given species in one zone, but statistically irrelevant for the same species in the other zone.

Regression analyses demonstrate that there are numerous relationships between plants and environmental variables that are apparent in either the upper or lower riparian zone, but not both. Ten such relationships are not identified at all when the riparian-wide analyses are performed. When the riparian-wide analysis does identify a relationship that exists in one zone and not the other, it almost always underestimates the strength of the relationship for the zone in which it truly exists, and falsely implies that there is a relationship in the other zone. If a relationship exists in both the upper and lower riparian zones, the nature of the relationships (positive or 
negative correlation) is always the same for both zones, but the strength of the relationships ( $\mathrm{R}^{2}$ values) is generally different, occasionally markedly so.

\section{Future Work}

The analysis of plant-environmental variable relationships focused on establishing whether there is a difference in plant-environmental variable dynamics between the upper and lower riparian zones. With the existence of such zonal differences established, future scientific studies and management activities should focus on species of concern and their specific relationships with a wider range of variables, as well as relationships between species (such as allelopathy and growth form interactions), within the upper zone and within the lower zone. Additional environmental variables should be examined for this and other river systems. Similar research should be conducted on other rivers with different riparian species, different soil types, different climates, and different flood regimes. This level of research could help lead to better scientific understanding of riparian ecosystem dynamics and to more effective site specific management techniques for desirable and undesirable species. 


\section{REFERENCES}

Adams, J.F. and J.W. Odom. 1985. Effects of $\mathrm{pH}$ and phosphorus rates on soilsolution phosphorus and phosphorus availability. Soil Science 140(3):202-205.

Allan, J. 1995. Stream Ecology: Structure and Function of Running Waters. Kluwer Academic Publishers. Dordrecht, The Netherlands.

Alt, D.D. and D.W. Hyndman. 2001. Roadside Geology of Oregon. Mountain Press Publishing Company, Missoula, Montana.

Ambasht, R.S., M.P. Singh, and E. Sharma. 1984. Soil, water, and nutrient conservation by certain riparian herbs. Journal of Environmental Management 18:99104.

Anbumozhi, V., J. Radhakishnan, E. Yamaji. 2005. Impact of riparian buffer zones on water quality. Ecological Engineering 24(5):517-523.

Anderson, M.G., T.P. Burt. 1982. The contribution of throughflow to storm runoff: an evaluation of a chemical mixing model. Earth Surface Processes and Landforms 33(1):211-225.

Anderson, M.G. and P.E. Kneale. 1980. Topography and hillslope soil water relationships in a catchment of low relief. Journal of Hydrology 47:115-128.

Angers, D. A. and Caron, J. 1998. Plant-induced changes in soil structure: Processes and feedbacks. Biogeochemistry 42:55-72.

Aringhieri, R. 2006. Saturated flow properties of different soil-sand systems as related to their particle- and micropore-size distributions: A comparative study. Soil Science 171(6): 448-455.

Asselman, N. and H. Middelkoop. 1995. Floodplain sedimentation - quantities, patterns, and processes. Earth Surface Processes 20(6):481-499.

Auble, G.T., J.M. Friedman, and M.L. Scott.1994. Relating riparian vegetation to present and future streamflow. Ecological Applications 4:544-554.

Bagstad, K.J., J.C. Stromberg, S.J. Lite. 2005. Response of herbaceous riparian plants to rain and flooding on the San Pedro River, Arizona, USA. Wetlands 25(1):210-223.

Baker, M. and B. Barnes. 1998. Landscape ecosystem diversity of river floodplains in northwestern lower Michigan, USA. Canadian Journal Of Forest Research 28:14051418. 
Barcholer, F. 1983. Seasonal variation of standing crop and digestibility of CPOM in a Swiss Jura stream. Ecology 64:1266-1272.

Bayley, P. B. 1995. Understanding large river-floodplain ecosystems. BioScience 45(3):153-148.

Bechtold, J.S. and R.J. Naiman. 2006. Soil texture and nitrogen mineralization potential across a riparian toposequence in a semi-arid savanna. Soil Biology and Biochemistry 38(6):1325-1333.

Beckham, S.D. and F.K. Lentz. 2000. ROCKS \& HARD PLACES: Historic Resources Study, John Day Fossil Beds National Monument, Oregon. National Park Service,United States Department of the Interior, Seattle, Washington.

Bendix, J. 1999. Stream power influence on southern Californian riparian vegetation. Journal of Vegetation Science 10(2):243-252.

Bendix, J. and C. R. Hupp. 2000. Hydrological and geomorphological impacts on riparian plant communities. Hydrological Processes 14:2977-2990.

Benson, J. 1996. Riparian Areas: Environmental Uniqueness, Functions, and Values. NRCS/RCA Issue Brief 11.

Blosl, M. and R. Conrad. 1992. Influence of an increased pH on the composition of the nitrate-reducing microbial populations in an anaerobically incubated acidic forest soil. Systematic and Applied Microbiology 15(4):624-627.

Bornette, G. and C. Amoros. 1996. Disturbance regimes and vegetation dynamics: role of floods in riverine wetlands. Journal of Vegetation Science 7:815-622.

Boudell, J.A. and J.C. Stromberg. 2008. Flood pulsing and metacommunity dynamics in a desert riparian ecosystem. Journal of Vegetation Science 19(3):373-380.

Bragg, D.C. and J.L. Kershner. 1999. Coarse woody debris in riparian zones Opportunity for interdisciplinary interaction. Journal of Forestry 97(4):30-35.

Bridge, J.S. 2003. Rivers and Floodplains: Forms, Processes, and Sedimentary Record. Blackwell Publishing. 491 pp.

Bridge, S.R.T., and E.A. Johnson. 2000. Geomorphic principles of terrain organization and vegetation gradients. Journal of Vegetation Sciences 11(1):57-70.

Burns, S.F. 1990. Soil Profiles *in* Magill, (ed.) Magill's Survey of Science: Earth Science Series 4:2409-2414. 
Castelli, R.M., J.C. Chambers, R.J. Tausch. 2000. Soil-plant relations along a soilwater gradient in great basin riparian meadows. Wetlands 20(2):251-266.

Cavalcanti, G.G. and B.G. Lockaby. 2006. Effects of sediment deposition on aboveground net primary productivity, vegetation composition, and structure in riparian forests. Wetlands 26(2):400-409

Chambers, C.C., R.R. Blank, D.C. Zamudio, and R. J. Tausch. 1999. Central Nevada riparian areas: Physical and chemical properties of meadow soils. Journal of Range Management 52:92-99.

Clarke, K.R. 1993. Non-parametric multivariate analyses of changes in community structure. Australian Journal of Ecology 18:117-143.

Clary, W. 1995. Vegetation and soil responses to grazing simulation on riparian meadows. Journal of Range Management 48:18-25.

Cowardin L., V. Carter, F. Golet, and E.LaRoe.1979. Classification of Wetlands and Deepwater Habitats of the United States. FWS/OBS-79?31, US Fish and Wildlife Service, Washington, DC.

Crawford, J.A. and R.D. Semlitsch. 2007. Estimation of core terrestrial habitat for stream-breeding salamanders and the delineation of riparian buffers for protection of biodiversity. Conservation Biology 21(1):152-158.

Cummins, K.W. 1974. Structure and function of stream ecosystems. Bioscience 24(11):631-641.

Daubenmire, R. 1959. A canopy-coverage method of vegetation analysis. Northwest Science 33:43-64.

Davies, P.E. and M. Nelson. 1994. Relationships between riparian buffer widths and the effects of logging on stream habitat, invertebrate community composition and fish abundance. Australian Journal of Marine and Freshwater Research 45(7):1289-1305.

Decker, A. M., G. A. Jung, J. B. Washko, D. D. Wolf, and M. J. Wright. 1967. Management and productivity of perennial grasses in the Northeast: I. Reed canarygrass. West Virginia University Agricultural Experiment Station, Morgantown, WV, USA. Bulletin 550T.

Dingman, S.L. 2002. Physical Hydrology. Prentice Hall, Inc., Upper Saddle River, New Jersey. 
Dobkin, D., A. Rich, and W. Pyle. 1998. Habitat and avifaunal recovery from livestock grazing in a riparian meadow system of the northwestern Great Basin. Conservation Biology 12:209-221.

Dong, W., Z. Yu, and D. Weber. 2003. Simulations on soil water variation in arid regions. Journal of Hydrology 275:162-181.

Dwire, K., J. Kauffman, and J. Baham. 2000. Relations among redox potentials, water levels, and riparian vegetation. Pg 23-28 in P.J. Wigington and R. Beschta (eds). Riparian Ecology and Management in Multi-land Use Watersheds. American Water Resources Association, Middleburg, VA.

Dwire, K.A., J.B. Kauffman, E.N.J. Brookshire, and J.E. Baham. 2004. Plant biomass and species composition along an environmental gradient in montane riparian meadows. Oecologia 139:309-317.

Florsheim, J.L. and J.F. Mount. 2002. Restoration of floodplain topography by sandsplay complex formation in response to intentional levee breaches, Lower Cosumnes River, California. Geomorphology 44:67-94.

Francis, R.A. 2006. Allogenic and autogenic influences upon riparian vegetation dynamics. Area 38(4):453-464.

Franklin, J. F. and C.T. Dyrness. 1988. Natural vegetation of Oregon and Washington. Corvallis, OR: Oregon State Univerity Press.

Frissell, C.A., W.J. Liss, and C.E. Warren. 1986. A hierarchical framework for stream habitat classification - viewing streams in a watershed context. Environmental Management 10(2):199-214.

Fritsch, E. and R.W. Fitzpatrick. 1994. Interpretation of soil features produced by ancient and modern processes in degraded landscapes: I. A new method for constructing conceptual soil-water-landscape models. Australian Journal of Soil Research 32:889-907.

Fullerton, A.H., T.J. Beechie, S.E. Baker. 2006. Regional patterns of riparian characteristics in the interior Columbia River basin, Northwestern USA: applications for restoration planning. Landscape Ecology 21(8):1347-1360.

Gary, H.L., S.R. Johnson, and S.L. Ponce. 1983. Cattle grazing impact on surface water quality in a Colorado Front Range stream. Journal of Soil and Water Conservation 38:124-128.

Gallardo, A. 2003. Spatial variability of soil properties in a floodplain forest in northwest Spain. Ecosystems 6(6):564-576. 
Gerrard, J. 2000. Fundamentals of Soils. Routledge, New York, New York.

Gomi, T. R.D. Moore, A.S. Dhakal. 2006. Headwater stream temperature response to clear-cut harvesting with different riparian treatments, coastal British Columbia, Canada. Water Resources Research 42(8):1-11.

Green, D. 1998. Recreation impacts on erosion and runoff in a central Arizona riparian area. Journal of Soil and Water Conservation 53:38-42.

Gregory, S.V., F. J. Swanson, W. A. McKee, and K.W. Cummins. 1991. An ecosystem perspective of riparian zones. BioScience 41:540-551.

Guard, B.J. 1995. Wetland Plants of Oregon and Washington. Lone Pine Publishing, Redmond, WA.

Harr, R.D. 1977. Water flux in soil and subsoil on a steep forested slope. Journal of Hydrology 33:37-58.

Harris, R.R. 1987. Occurrence of vegetation on geomorphic surfaces in the active floodplain of a California alluvial stream. American Midland Naturalist 118(2):393 405.

He, Q., and D. E. Walling. 1997. Spatial variability of the particle size composition of overbank floodplain deposits. Water, Air, and Soil Pollution 99:71-80.

Helmers, M.J., D.E. Eisenhauer, and D.E. Franti. 2005. Modeling sediment trapping in a vegetative filter accounting for converging overland flow. Transactions of the ASAE 48(2):541-555.

Hitchcock, C.L. and A. Cronquist. 1973. Flora of the Pacific Northwest. University of Washington Press, Seattle, WA.

Hobbs, R.J. and Huenneke, L.F. 1992. Disturbance, diversity, and invasion:

implications for conservation. Conservation Biology 6:324-337.

Hornberger, G.M., K.E. Bencala, D.M. McKnight. 1994. Hydrological controls on dissolved organic carbon during snowmelt in the Snake River near Montezuma, Colorado. Biogeochemistry 41:175-197.

Hosler, R.E. 1977. Soil Survey of Gilliam County, Oregon. USDA, Soil Conservation Service and Oregon Agricultural Experiment Station.

Hughes, F.M.R. 1997. Floodplain biogeomorphology. Progress in Physical Geography 21(4):501-529. 
Hunter, W.C., B.W. Anderson, and R.D. Ohmart. 1987. Avian community structure changes in a mature floodplain forest after extensive flooding. Journal of Wildlife Management 51:495-502.

Hupp, C. R. and W. R. Osterkamp. 1996. Riparian vegetation and fluvial geomorphic processes. Geomorphololgy 14:277-295.

Jenkins, N.J, J.A. Yeakley, and E.M. Stewart. 2008. First-year responses to managed flooding of lower Columbia River bottomland vegetation dominated by Phalaris Arundinacea. Wetlands 28(4):1018-1027.

Kalliola, R. and M. Puhakka. 1988. River dynamics and vegetation mosaicism: a case study of the River Kamajohka, northernmost Finland. Journal of Biogeography 15:703-719.

Karr, J.R. and I.J. Schlosser. 1978. Water-resources and land-water interface. Science 201:229-234.

Karrenberg, S., P.J. Edwards, and J. Kollmann. 2002. The life history of Salicaceae living in the active zone of floodplains. Freshwater Biology 47:733-748.

Katz, S.L., K. Barnas, R. Hicks. 2007. Freshwater habitat restoration actions in the Pacific Northwest: A decade's investment in habitat improvement. Restoration Ecology .15(3):494-505.

Kaufman, J., W. Krueger, and M. Vavra. 1983. Effects of late season cattle grazing on riparian plant communities. Journal of Range Management 36:685-691.

Kiffney, P.M., J.S. Richardson, J.P. Bull. 2004. Establishing light as a causal mechanism structuring stream communities in response to experimental manipulation of riparian buffer width. Journal of the North American Benthological Society 23(3):542-555.

Knopf, F.L. and Sedgwick, J.A. 1992. An experimental study of nest-site selection by yellow warblers. Condor 94:734-742.

Kovacic, D., M. David, L. Gentry, K. Starks, and R. Cooke. 2000. Effectiveness of constructed wetlands in reducing nitrogen and phosphorus export from agricultural tile drainage. Journal of Environmental Quality 29:1262-1274.

Lavergne, S. and J. Molofsky. 2004. Reed canary grass (Phalaris arundinacea) as a biological model in the study of plant invasions. Critical Reviews in Plant Sciences 23:415-29. 
Law, D.J., C.B. Marlow, J.C. Mosley, S. Custer, P. Hook, and B. Leinard. 2000. Water table dynamics and soil texture of three riparian plant communities. Northwest Science 74(3):234-241.

Lewis, L., L. Clark, R. Klapf, M. Manning, J. Staats, T. Subirge, L. Townsend, B. Ypsilantis. 2003. Riparian Area Management: Riparian-wetland soils. U.S. Department of the Interior - Bureau of Land Management. TR 1737-19.

Likens, G.E. 1984. Beyond the shoreline: A watershed ecosystem approach. Proceedings of the International Association of Theoretical and Applied Limnology 22:1-22.

Litaor, M.I. 1992. Aluminum mobility along a geochemical catena in an alpine watershed, front range, Colorado. Catena 19:1-16.

Lite, S.J., K.J. Bagstad, J.C. Stromberg. 2005. Riparian plant species richness along lateral and longitudinal gradients of water stress and flood disturbance, San Pedro River, Arizona, USA. Journal of Arid Environments 63(4):785-813.

Lowrance, R., R. Todd, J. Fail, O. Hendrickson, R. Leonard, L. Asmussen. 1984. Riparian forests as nutrient filters in agricultural watersheds. Bioscience 34(6):374377.

Lowrance, R. and J.M. Sheridan. 2005. Surface runoff water quality in a managed three zone riparian buffer. Journal of Environmental Quality 34(5):1851-1859.

Macdonald, D.G., J.M. Lamkin, R.H. Borine.1964. Soil Survey, Sherman County, Oregon. USDA, Soil Conservation Service and Oregon Agricultural Experiment Station.

Malanson, G.P. and D.R. Bulter. 1990. Woody debris, sediment, and riparian vegetation of a sub-alpine river, Montana, USA. Arctic and Alpine Research 22(2):183-194.

Malanson, G.P. 1993. Riparian Landscapes. Cambridge University Press. Cambridge, NY.

Manning, R. 1979. Impacts of recreation on riparian soils and vegetation. Water Resources Bulletin 15:30-43.

Marriot, S. 1992. Textural analysis and modeling of a flood deposit: River Severn, UK. Earth Surface Process and Landforms 17:687-697.

Martin, D, and J. Chambers. 2002. Restoration of riparian meadows degraded by livestock grazing: above- and belowground responses. Plant Ecology 163(1):77-91. 
McBride, J.R. and J. Strahan. 1984. Establishment and survival of woody riparian species on gravel bars of an intermittent stream. American Midland Naturalist 112:235-245.

McCune, B. and Grace, J. 2002. Analysis of Ecological Communities. Mjm Software Design (August 2002).

Melillo, J.M., J.D. Aber, J.F. Muratore. 1982. Nitrogen and lignin control of hardwood leaf litter decomposition dynamics. Ecology 63:621-626.

Mergen, D., M. Trlica, J. Smith, and W. Blackburn. 2001. Stratification of variability in runoff and sediment yield based on vegetation characteristics. Journal of the American Water Resources Association 37:617-628.

Miller, R. C. and J. B. Zedler. 2003. Responses of native and invasive wetland plants to hydroperiod and water depth. Plant Ecology 167:57-69.

Mitsch, W. and J. Gosselink. 2000. Wetlands. 3rd ed. John Wiley and Sons, Inc., New York.

Mueller R.C., C.M. Scudder, M.E. Porter, R.T. Trotter, C.A. Gehring, and T.G. Whitham. 2005. Differential tree mortality in response to severe drought: evidence for long-term vegetation shifts. Journal of Ecology 93(6):1085-1093.

Naiman, R. J., H. DeCamps, M. Pollock. 1993. The role of riparian corridors in maintaining regional biodiversity. Ecological Applications 3(2):209-212.

Naiman, R.J. and H. Decamps. 1997. The ecology of interfaces: Riparian zones. Annual Review of Ecology and Systematics 28:261-658.

Nassif, S.H. and E.M. Wilson. 1975. The influence of slope and rain intensity on runoff and infiltration. Hydrological Sciences Bulletin 20:539-553.

Opperman, J.J and A.M. Merenlender. 2004. The effectiveness of riparian restoration for improving instream fish habitat in four hardwood-dominated California streams. North American Journal of Fisheries Management 24(3):822-834.

Oregon Department of Environmental Quality (ODEQ). 1988. Oregon Statewide Assessment of Nonpoint Sources of Water Pollution. Planning \& Monitoring Section, Water Quality Division, Oregon Department of Environmental Quality. Portland, OR.

Oregon Water Resources Department. 1986. John Day River Basin Report. William H. Young, Director. State of Oregon Water Resources Department, Salem, OR. 
Orr, E.L., W.N. Orr., E.M. Baldwin 1992. Geology of Oregon. 4th edition. Kendall/Hunt Publishing Company, Dubuque, IA.

Parkin, T.B., A.J. Sexstone, J.M. Tiedje. 1985. Adaptation of denitrifying populations to low soil-pH. Applied and Environmental Microbiology 49(5):1053-1056.

Patten, D. T. 1998. Riparian ecosystems of semi-arid North America: diversity and human impacts. Wetlands 18:498-512.

Pennington, D.N., J. Hansel, R.B. Blair. 2008.The conservation value of urban riparian areas for landbirds during spring migration: Land cover, scale, and vegetation effects. Biological Conservation 141(5):1235-1248.

Pezeshki, S.R., P.H. Anderson, and F.D. Shields. 1998. Effects of soil moisture regimes on growth and survival of black willow (Salix nigra) posts (cuttings). Wetlands 18(3):460-470.

Pinder, G.F. and J.F. Jones. 1969. Determination of the groundwater component of peak discharge from the chemistry of total runoff. Water Resources Research $5(2): 438-445$.

Poff, N.L., J.D. Allan, M.B. Bain, J.R. Karr, K.L Prestegaard, B.D. Richter, R.E. Sparks, and J.C. Stromberg. 1997. The natural flow regime: a paradigm for river conservation and restoration. BioScience 47:769-784.

Pusey, B.J. and A.H. Arthington. 2003. Importance of the riparian zone to the conservation and management of freshwater fish: a review. Marine and Freshwater Research 54(1):1-16.

Raven, P., R. Ever, and S. Eichhorn. 1998. Biology of Plants. W.H. Freeman and Company, New York.

Richter, B. D. and H. E. Richter. 2000. Prescribing flood regimes to sustain riparian ecosystems along meandering rivers. Conservation Biology 14(5):1467-1478.

Rickard, W. and C. Cushing. 1982. Recovery of streamside woody vegetation after exclusion of livestock grazing. Journal of Range Management 35:360-361.

Robertson, P.A., G.T. Weaver, and J.A. Cavanaugh. 1978. Vegetation and tree species paterns near the north terminus of the southern floodplain forest. Ecological Monographs 48:249-267.

Rood, S.B. and J.M. Mahoney. 1995. River damming and riparian cottonwoods along the Marias River, Montana. Rivers 5:195-207. 
Rood, S.B., A.R. Kalischuk, J.M. Mahoney. 1998. Initial cottonwood seedling recruitment following the flood of the century of the Oldman River, Alberta, Canada. Wetlands 18(4):557-570.

Royer, F. and R. Dickinson. 1999. Weeds of the northern US and Canada: a guide for identification. Lone Pine Publishing, USA.

Salinas, M.J., J.J. Casas. 2007. Riparian vegetation of two semi-arid Mediterranean rivers: basin-scale responses of woody and herbaceous plants to environmental gradients. Wetlands 27(4):831-845.

Sanders, T.A. and Edge, D.E. 1998. Breeding bird community composition in relation to riparian vegetation structure in the western United States. Journal of Wildlife Management 62:461-473

Sanzone, D.M., J.L. Meyer, E. Marti, E.P. Gardiner, J.L. Tank, and N.B. Grimm. 2003. Carbon and nitrogen transfer from a desert stream to riparian predators.

Oecologia 134:238-250.

Schade, J.D., J.R. Welter, E. Marti, N.B. Grimm. 2005. Hydrologic exchange and N uptake by riparian vegetation in an arid-land stream. North American Benthological Society $24(1): 19-28$.

Schiemer, F. and M. Zalewski. 1992. The importance of riparian ecotones for diversity and productivity or riverine fish communities. Netherlands Journal of Zoology 42(23):323-335.

Scott, M.L., G.T. Auble, J.M. Friedman. 1997. Flood dependency of cottonwood establishment along the Missouri River, Montana, USA. Ecological Applications $7: 677-690$.

Seelig, B.D. and R.L. Richardson. 1994. Sodic soil toposequence related to focused water flow. Soil Science Society of America Journal 58:156-213.

Shafroth, P.B., G.T. Auble, J.C. Stromberg, D.T. Patten. 1998. Establishment of woody riparian vegetation in relation to annual patterns of streamflow, Bill Williams River, Arizona. Wetlands 18(4):577-590.

Shafroth, P. B., J. C. Stromberg, D. T. Patten. 2002. Riparian vegetation responses to altered disturbance and stress regimes. Ecological Applications 12(1):107-123.

Shah, J.J.F., C.N. Dahm, S.P. Gloss. 2007. River and riparian restorationin the southwest: Results of the national river restoration science synthesis project. Restoration Ecology 15(3):550-562. 
Sharp, M. 2002. Effects of physical soil properties on the coverage of native and nonnative plants in urban riparian areas. Master of Science Thesis: Portland State University, Portland, Oregon.

Simon, A. and A.J.C. Collinson. 2002. Quantifying the mechanical and hydrologic effects of riparian vegetation on streambank stability. Earth Surface Processes and Landforms 27(5):527-546.

Sims, J.L. and W.H. Patrick. 1978. Distribution of micronutrient cations in soil under conditions of varying redox potential and $\mathrm{pH}$. Soil Science Society of America Journal 42(2):258-262.

Skagen, S.K., J.F. Kelley, C. Van Riper. 2005. Geography of spring landbird migration through riparian habitats in southwestern North America. Condor 107(2):212-227.

Smith, S.D., A.B. Wellington, J.L. Nachlinger, and C.A. Fox: 1991. Functional responses of riparian vegetation to streamflow diversion in the eastern Sierra Nevada. Ecological Applications 1(1):89-97.

Smith, S.D., D.A. Devitt, A. Sala, J.R. Cleverly, D.E. Busch. 1998. Water relations of riparian plants from warm desert regions. Wetlands 18(4): 687-696.

Steel, E.A., R.J. Naiman, S.D. West. 1999. Use of woody debris piles by birds and small mammals in a riparian corridor, Northwest Science 73(1):19-26.

Stromberg, J. C., J. Fry, and D. T. Patten. 1997. Marsh development after large floods in an alluvial, arid-land river. Wetlands 17(2):292-300.

Ticehurst, J.L., H.P. Cresswell, N.J. McKenzie, M.R. Glover. 2006. Interpreting soil and topographic properties to conceptualise hillslope hydrology. Geoderma 137:279292.

Tockner, K. and J.V. Ward. 1999. Biodiversity along riparian corridors. Archiv Fur Hydrobiologie 3:293-310.

US Army Corps of Engineers. 1987. Wetlands Delineation Manual. Technical Report Y-87-1. Department of the Army, Waterways Experiment Station, Vicksburg, MS.

USDI, Bureau of Land Management.2000. John Day River Proposed Management Plan, Two Rivers and John Day Resource Management Plan Amendments and Final Environmental Impact Statement. Prineville, Oregon.

US Department of Fish and Wildlife Service. 1997. National List of Vascular Plant Species that Occur in Wetlands: 1996 National Summary. 
Vannote, R.L., G.W. Minshall, K.W. Cummins K.W. 1980. The river continuum concept. Canadian Journal of Fisheries and Aquatic Sciences 37(1):130-137.

Vercoutere, B., O. Honnay, M. Hermy. 2007. Vegetation response after restoring the connectivity between a river channel and its floodplain. Applied Vegetation Science $10(2): 271-278$.

Walling, D. E. and Q. He. 1997. Investigating spatial patterns of overbank sedimentation on river floodplains. Water, Air, and Soil Pollution 99:9-20.

Webster, J.R. and Benfield, E.F. 1986. Vascular plant breakdown in freshwater ecosystems. Annual Review of Ecology and Systematics 17:567-594.

Weiler, M. and J.J. McDonnell. 2006. Testing nutrient flushing hypotheses at the hillslope scale: A virtual experiment approach. Journal of Hydrology 319:339-356.

Weyman, D.R. 1973. Measurements of the downslope flow of water in a soil. Journal of Hydrology 20:267-288.

Wilcox, B.P., M.K. Wood, J.M. Tromble. 1988. Factors influencing infiltrability of semiarid mountain slopes. Journal of Range Management 41(3):197-206.

Wilcox, B.P. and M.K. Wood. 1989. Factors influencing interrill erosion from semiarid slopes in New Mexico. Journal of Range Management 42(1):66-70.

Willems, H.P.L., M.D. Rotelli, D.F. Berry, E.P. Smith, R.B. Reneau, S. Mostaghimi. 1997. Nitrate removal in riparian wetland soils: effects of flow rate, temperature, nitrate concentration, and soil depth. Water Resources 31(4):841-849.

Wintle, B.C. and J.B. Kirkpatrick. 2007. The response of riparian vegetation to floodmaintained habitat heterogeneity. Austral Ecology 32(5):592-599.

Wissmar, R.C. 2004. Riparian corridors of eastern Oregon and Washington: functions and sustainability along lowland-arid to mountain gradients. Aquatic Sciences 66(4):373-387.

Wright, K.A., K.H. Sendek, R.M. Rice, R.B. Thomas. 1990. Logging effects on streamflow: Storm runoff in Caspar Creek in northwestern California. Water Resources Research 26:1657-1667.

Zar, J. 1999. Biostatistical Analysis. 4th ed. Prentice Hall, Inc., Englewood Cliffs, NJ. 


\section{APPENDIX A: SINGLE LINEAR REGRESSION ANALYSIS DETAILED}

\section{RESULTS .}

Table A-1. Xanthium strumarium \% Quadrat Cover vs. Environmental Variables, Single Linear Regressions Test Results

\begin{tabular}{|c|c|c|c|c|c|c|}
\hline \multirow[b]{2}{*}{ All Sites } & \multicolumn{2}{|c|}{ Relationships: + (Positive) } & - (Negative) & \multicolumn{3}{|c|}{ Shaded (No Relationship, P > 0.05} \\
\hline & $\begin{array}{l}\text { A Horizon } \\
\text { Depth }\end{array}$ & $\begin{array}{c}\text { Average } 3 \\
\text { Meter Slope }\end{array}$ & pH & $\begin{array}{l}\% 2.0 \mathrm{~mm} \\
\text { to } 600 \mu \mathrm{m}\end{array}$ & $\begin{array}{l}\% 600 \mu \mathrm{m} \\
\text { to } 212 \mu \mathrm{m}\end{array}$ & $\begin{array}{l}\% 125 \mu \mathrm{m} \\
\text { to } 63 \mu \mathrm{m}\end{array}$ \\
\hline$P$ & 0.023 & 0.032 & & 0.002 & 0.047 & \\
\hline Adjusted $\mathrm{R}^{2}$ & 0.07 & 0.061 & & 0.134 & 0.05 & \\
\hline Relationship & + & + & & - & + & \\
\hline $\begin{array}{l}\text { Upper } \\
\text { Riparian } \\
\end{array}$ & $\begin{array}{l}\text { A Horizon } \\
\text { Depth }\end{array}$ & $\begin{array}{c}\text { Average } 3 \\
\text { Meter Slope }\end{array}$ & pH & $\begin{array}{l}\% 2.0 \mathrm{~mm} \\
\text { to } 600 \mu \mathrm{m}\end{array}$ & $\begin{array}{l}\% 600 \mu \mathrm{m} \\
\text { to } 212 \mu \mathrm{m}\end{array}$ & $\begin{array}{l}\% 125 \mu \mathrm{m} \\
\text { to } 63 \mu \mathrm{m}\end{array}$ \\
\hline$P$ & & & & & & \\
\hline Adjusted $\mathrm{R}^{2}$ & & & & & & \\
\hline Relationship & & & & & & \\
\hline $\begin{array}{l}\text { Lower } \\
\text { Riparian }\end{array}$ & $\begin{array}{c}\text { A Horizon } \\
\text { Depth }\end{array}$ & $\begin{array}{c}\text { Average } 3 \\
\text { Meter Slope }\end{array}$ & pH & $\begin{array}{l}\% 2.0 \mathrm{~mm} \\
\text { to } 600 \mu \mathrm{m}\end{array}$ & $\begin{array}{l}\% 600 \mu \mathrm{m} \\
\text { to } 212 \mu \mathrm{m}\end{array}$ & $\begin{array}{l}\% 125 \mu \mathrm{m} \\
\text { to } 63 \mu \mathrm{m}\end{array}$ \\
\hline$P$ & 0.003 & & 0.026 & 0.018 & 0.007 & 0.024 \\
\hline Adjusted $\mathrm{R}^{2}$ & 0.252 & & 0.135 & 0.156 & 0.206 & 0.14 \\
\hline Relationship & + & & - & - & + & - \\
\hline
\end{tabular}


Table A-2. Phalaris arundinacea \% Quadrat Cover vs. Environmental Variables, Single Linear Regressions Test Results

\begin{tabular}{|c|c|c|c|}
\hline \multirow[b]{2}{*}{ All Sites } & \multicolumn{2}{|c|}{ Relationships: + (Positive) - (Negative) } & Shaded (No Relationship, $P>0.05$ ) \\
\hline & A Horizon Depth & & $\% 125 \mu \mathrm{m}$ to $63 \mu \mathrm{m}$ \\
\hline$P$ & $<0.001$ & & 0.038 \\
\hline Adjusted $\mathrm{R}^{2}$ & 0.259 & & 0.056 \\
\hline Relationship & + & & + \\
\hline $\begin{array}{l}\text { Upper } \\
\text { Riparian }\end{array}$ & A Horizon Depth & & $\% 125 \mu m$ to $63 \mu m$ \\
\hline $\mathbf{P}$ & 0.049 & & \\
\hline Adjusted $R^{2}$ & 0.1 & & \\
\hline Relationship & + & & \\
\hline $\begin{array}{l}\text { Lower } \\
\text { Riparian }\end{array}$ & A Horizon Depth & & $\% 125 \mu \mathrm{m}$ to $63 \mu \mathrm{m}$ \\
\hline $\mathbf{P}$ & & & \\
\hline Adjusted $\mathrm{R}^{2}$ & & & \\
\hline Relationship & & & \\
\hline
\end{tabular}

Table A-3. Equisetum arevense \% Quadrat Cover vs. Environmental Variables, Single Linear Regressions Test Results

\begin{tabular}{|c|c|c|c|c|c|c|}
\hline \multirow[b]{2}{*}{ All Sites } & \multicolumn{2}{|c|}{ Relationships: + (Positive) } & - (Negative & \multicolumn{3}{|c|}{ Shaded (No Relationship, $P>0.05$ ) } \\
\hline & $\begin{array}{l}\text { A Horizon } \\
\text { Depth } \\
\end{array}$ & $\begin{array}{c}\text { Average } 3 \\
\text { Meter Slope }\end{array}$ & $\%$ Clay & $\begin{array}{l}\% 2.0 \mathrm{~mm} \\
\text { to } 600 \mu \mathrm{m}\end{array}$ & $\begin{array}{l}\% 600 \mu \mathrm{m} \\
\text { to } 212 \mu \mathrm{m}\end{array}$ & $\begin{array}{l}\% 125 \mu \mathrm{m} \\
\text { to } 63 \mu \mathrm{m}\end{array}$ \\
\hline$P$ & 0.009 & & & 0.008 & & \\
\hline Adjusted $\mathrm{R}^{2}$ & 0.096 & & & 0.1 & & \\
\hline Relationship & - & & & + & & \\
\hline $\begin{array}{l}\text { Upper } \\
\text { Riparian }\end{array}$ & $\begin{array}{l}\text { A Horizon } \\
\text { Depth }\end{array}$ & $\begin{array}{c}\text { Average } 3 \\
\text { Meter Slope }\end{array}$ & $\%$ Clay & $\begin{array}{l}\% 2.0 \mathrm{~mm} \\
\text { to } 600 \mu \mathrm{m}\end{array}$ & $\begin{array}{l}\% 600 \mu \mathrm{m} \\
\text { to } 212 \mu \mathrm{m}\end{array}$ & $\begin{array}{l}\% 125 \mu \mathrm{m} \\
\text { to } 63 \mu \mathrm{m}\end{array}$ \\
\hline$P$ & & 0.015 & 0.018 & & & \\
\hline Adjusted $\mathrm{R}^{2}$ & & 0.165 & 0.156 & & & \\
\hline Relationship & & - & + & & & \\
\hline $\begin{array}{l}\text { Lower } \\
\text { Riparian }\end{array}$ & $\begin{array}{l}\text { A Horizon } \\
\text { Depth }\end{array}$ & $\begin{array}{c}\text { Average } 3 \\
\text { Meter Slope }\end{array}$ & $\%$ Clay & $\begin{array}{l}\% 2.0 \mathrm{~mm} \\
\text { to } 600 \mu \mathrm{m}\end{array}$ & $\begin{array}{l}\% 600 \mu \mathrm{m} \\
\text { to } 212 \mu \mathrm{m}\end{array}$ & $\begin{array}{l}\% 125 \mu \mathrm{m} \\
\text { to } 63 \mu \mathrm{m}\end{array}$ \\
\hline $\mathrm{P}$ & & & & & 0.05 & 0.035 \\
\hline Adjusted $\mathrm{R}^{2}$ & & & & & 0.099 & 0.119 \\
\hline Relationship & & & & & - & + \\
\hline
\end{tabular}


Table A-4. Scirpus americana \% Quadrat Cover vs. Environmental Variables, Single Linear Regressions Test Results

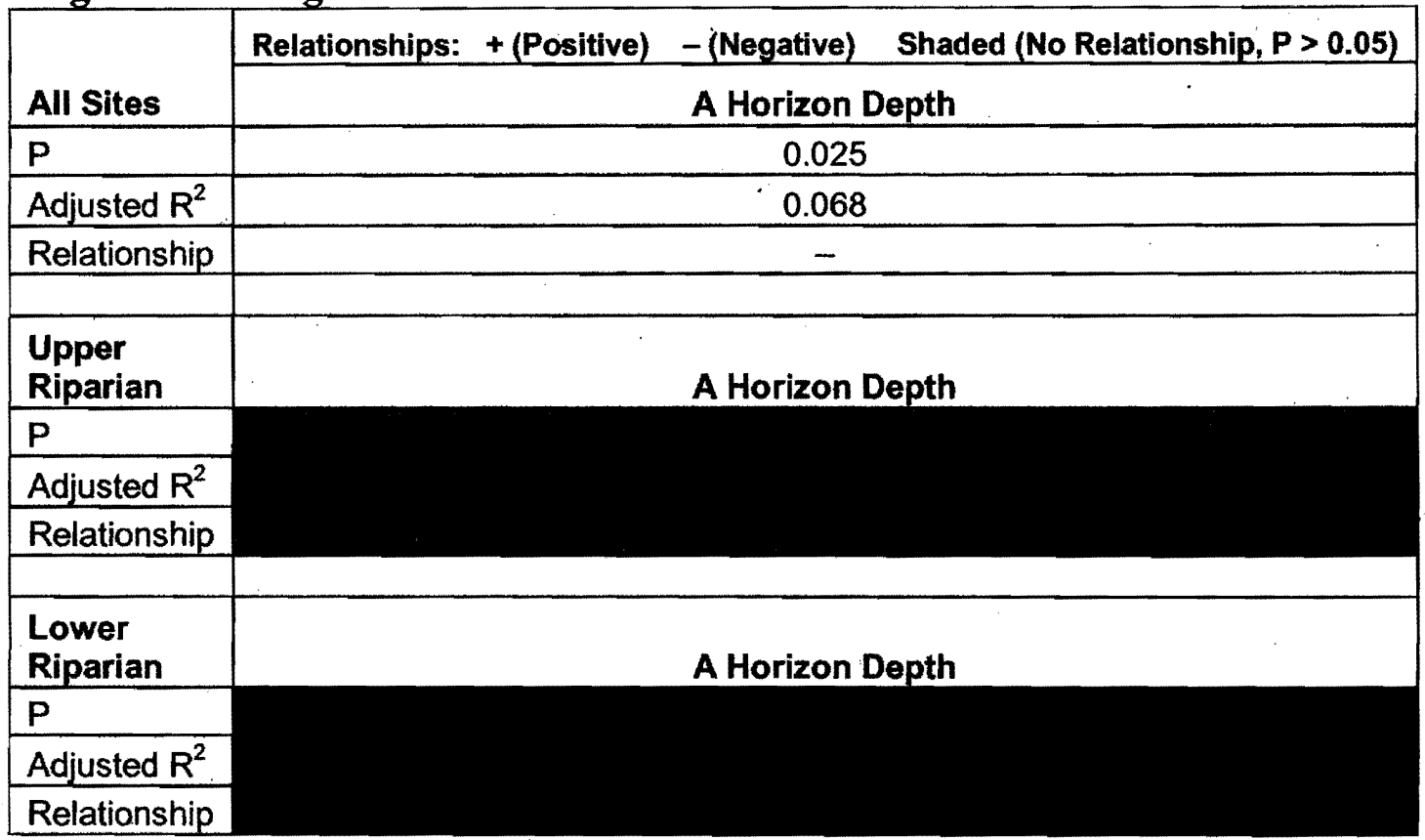

Table A-5. Agropyron repens \% Quadrat Cover vs. Environmental Variables, Single Linear Regressions Test Results

\begin{tabular}{|c|c|c|c|}
\hline \multirow[b]{2}{*}{ All Sites } & Relationships: + (Positive) & - (Negative) & Shaded (No Relationship, $P>0.05$ ) \\
\hline & A Horizon Depth & \multicolumn{2}{|r|}{ Average 3 Meter Slope } \\
\hline$P$ & 0.036 & \multicolumn{2}{|r|}{0.04} \\
\hline Adjusted $\mathrm{R}^{2}$ & 0.058 & \multicolumn{2}{|r|}{0.054} \\
\hline Relationship & + & \multicolumn{2}{|r|}{+} \\
\hline $\begin{array}{l}\text { Upper } \\
\text { Riparian }\end{array}$ & A Horizon Depth & \multicolumn{2}{|r|}{ Average 3 Meter Slope } \\
\hline$P$ & & \multicolumn{2}{|r|}{0.039} \\
\hline Adjusted $\mathrm{R}^{2}$ & & \multicolumn{2}{|r|}{0.113} \\
\hline Relationship & & \multicolumn{2}{|r|}{+} \\
\hline $\begin{array}{l}\text { Lower } \\
\text { Riparian }\end{array}$ & A Horizon Depth & \multicolumn{2}{|r|}{ Average 3 Meter Slope } \\
\hline$P$ & & & \\
\hline \multicolumn{4}{|l|}{ Adjusted $\mathrm{R}^{2}$} \\
\hline Relationship & & & \\
\hline
\end{tabular}


Table A-6. Cyperus aristatus \% Quadrat Cover vs. Environmental Variables, Single Linear Regressions Test Results

\begin{tabular}{|c|c|c|c|}
\hline \multirow[b]{2}{*}{ All Sites } & \multirow{2}{*}{$\begin{array}{c}\text { Relationships: + (Positive) } \\
\% \text { 600 } \mu \mathrm{m} \text { to } 212 \mu \mathrm{m}\end{array}$} & \multirow[t]{2}{*}{ - (Negative) } & Shaded (No Relationship, P > 0.05) \\
\hline & & & $\% 125 \mu m$ to $63 \mu \mathrm{m}$ \\
\hline $\mathbf{P}$ & 0.001 & & 0.015 \\
\hline Adjusted $\mathrm{R}^{2}$ & 0.152 & & 0.082 \\
\hline Relationship & + & & - \\
\hline . & & & \\
\hline $\begin{array}{l}\text { Upper } \\
\text { Riparian }\end{array}$ & $\% 600 \mu m$ to $212 \mu m$ & & $\% 125 \mu m$ to $63 \mu \mathrm{m}$ \\
\hline $\mathrm{P}$ & & & \\
\hline Adjusted $\mathrm{R}^{2}$ & & & \\
\hline Relationship & & & \\
\hline $\begin{array}{l}\text { Lower } \\
\text { Riparian }\end{array}$ & $\% 600 \mu m$ to $212 \mu \mathrm{m}$ & & $\% 125 u m$ to $63 \mu m$ \\
\hline $\mathrm{P}$ & 0.018 & & \\
\hline Adjusted $\mathrm{R}^{2}$ & 0.155 & & \\
\hline Relationship & + & & \\
\hline
\end{tabular}

Table A-7. Eleocharis palustris \% Quadrat Cover vs. Environmental Variables, Single Linear Regressions Test Results

\begin{tabular}{|c|c|c|c|c|}
\hline \multirow[b]{2}{*}{ All Sites } & \multicolumn{2}{|c|}{ Relationships: + (Positive) } & \multicolumn{2}{|c|}{- (Negative) Shaded (No Relationship, $P>0.05$ ) } \\
\hline & \%Sand & & \%Silt & \begin{tabular}{c|c} 
\%Clay \\
\end{tabular} \\
\hline $\mathrm{P}$ & 0.006 & & 0.006 & 0.04 \\
\hline Adjusted $\mathrm{R}^{2}$ & 0.108 & & 0.11 & 0.055 \\
\hline Relationship & - & & + & + \\
\hline $\begin{array}{l}\text { Upper } \\
\text { Riparian } \\
\end{array}$ & \%Sand & & $\%$ Silt & \%Clay \\
\hline $\mathrm{P}$ & & & & \\
\hline Adjusted $\mathrm{R}^{2}$ & & & & \\
\hline Relationship & & & & \\
\hline $\begin{array}{l}\text { Lower } \\
\text { Riparian }\end{array}$ & \%Sand & & $\%$ Silt & $\%$ Clay \\
\hline$P$ & $<0.001$ & & $<0.001$ & 0.002 \\
\hline Adjusted $\mathrm{R}^{2}$ & 0.338 & & 0.335 & 0.28 \\
\hline Relationship & - & & + & + \\
\hline
\end{tabular}


Table A-8. Euphorbia supina \% Quadrat Cover vs. Environmental Variables, Single Linear Regressions Test Results

\begin{tabular}{|c|c|c|}
\hline \multirow[b]{2}{*}{ All Sites } & Relationships: + (Positive) & - (Negative) Shaded (No Relationship, $P>0.05$ ) \\
\hline & \multicolumn{2}{|r|}{ A Horizon Depth } \\
\hline \multicolumn{3}{|l|}{$\mathrm{P}$} \\
\hline \multicolumn{3}{|l|}{ Adjusted $\mathrm{R}^{2}$} \\
\hline \multicolumn{3}{|l|}{ Relationship } \\
\hline $\begin{array}{l}\text { Upper } \\
\text { Riparian }\end{array}$ & \multicolumn{2}{|r|}{ A Horizon Depth } \\
\hline \multicolumn{3}{|l|}{$P$} \\
\hline \multicolumn{3}{|l|}{ Adjusted $\mathrm{R}^{2}$} \\
\hline \multicolumn{3}{|l|}{ Relationship } \\
\hline $\begin{array}{l}\text { Lower } \\
\text { Riparian }\end{array}$ & \multicolumn{2}{|r|}{ A Horizon Depth } \\
\hline $\mathrm{P}$ & \multicolumn{2}{|r|}{0.01} \\
\hline Adjusted $\mathrm{R}^{2}$ & \multicolumn{2}{|r|}{0.186} \\
\hline Relationship & \multicolumn{2}{|r|}{+} \\
\hline
\end{tabular}

Table A-9. Glycyrrhiza lepidota \% Quadrat Cover vs. Environmental Variables, Single Linear Regressions Test Results

\begin{tabular}{|c|c|c|c|}
\hline \multirow[b]{2}{*}{ All Sites } & \multicolumn{2}{|c|}{ Relationships: + (Positive) - (Negative) } & Shaded (No Relationship, $P>0.05$ ) \\
\hline & A Horizon Depth & & Average 3 Meter Slope \\
\hline$P$ & 0.004 & & 0.003 \\
\hline Adjusted $\mathrm{R}^{2}$ & 0.12 & & 0.128 \\
\hline Relationship & - & & - \\
\hline $\begin{array}{l}\text { Upper } \\
\text { Riparian }\end{array}$ & A Horizon Depth & & Average 3 Meter Slope \\
\hline $\mathrm{P}$ & 0.007 & & \\
\hline Adjusted $\mathrm{R}^{2}$ & 0.205 & & \\
\hline Relationship & - & & \\
\hline $\begin{array}{l}\text { Lower } \\
\text { Riparian }\end{array}$ & A Horizon Depth & & Average 3 Meter Slope \\
\hline$P$ & 0.02 & & 0.016 \\
\hline Adjusted $\mathrm{R}^{2}$ & 0.149 & & 0.162 \\
\hline Relationship & - & & - \\
\hline
\end{tabular}


Table A-10. Leersia oryzoides \% Quadrat Cover vs. Environmental Variables, Single Linear Regressions Test Results

\begin{tabular}{|c|c|}
\hline \multirow[b]{2}{*}{ All Sites } & Relationships: + (Positive) - (Negative) Shaded (No Relationship, P>0.05) \\
\hline & A Horizon Depth \\
\hline $\mathbf{P}$ & \\
\hline Adjusted $\mathrm{R}^{2}$ & \\
\hline Relationship & \\
\hline $\begin{array}{l}\text { Upper } \\
\text { Riparian }\end{array}$ & A Horizon Depth \\
\hline$P$ & \\
\hline Adjusted $\mathrm{R}^{2}$ & \\
\hline Relationship & \\
\hline $\begin{array}{l}\text { Lower } \\
\text { Riparian }\end{array}$ & A Horizon Depth \\
\hline$P$ & 0.008 \\
\hline Adjusted $\mathrm{R}^{2}$ & 0.196 \\
\hline Relationship & + \\
\hline
\end{tabular}

Table A-11. Mentha arvensis \% Quadrat Cover vs. Environmental Variables, Single Linear Regressions Test Results

\begin{tabular}{|c|c|c|}
\hline \multirow[b]{2}{*}{ All Sites } & Relationships: + (Positive) & - (Negative) Shaded (No Relationship, $P>0.05$ ) \\
\hline & \multicolumn{2}{|r|}{ A Horizon Depth } \\
\hline $\mathrm{P}$ & \multicolumn{2}{|r|}{0.05} \\
\hline Adjusted $\mathrm{R}^{2}$ & \multicolumn{2}{|r|}{0.048} \\
\hline Relationship & \multicolumn{2}{|r|}{-} \\
\hline $\begin{array}{l}\text { Upper } \\
\text { Riparian }\end{array}$ & \multicolumn{2}{|r|}{ A Horizon Depth } \\
\hline \multicolumn{3}{|l|}{$P$} \\
\hline \multicolumn{3}{|l|}{ Adjusted $\mathrm{R}^{2}$} \\
\hline \multicolumn{3}{|l|}{ Relationship } \\
\hline $\begin{array}{l}\text { Lower } \\
\text { Riparian }\end{array}$ & \multicolumn{2}{|r|}{ A Horizon Depth } \\
\hline$P$ & & \\
\hline Adjusted $\mathrm{R}^{2}$ & & \\
\hline Relationship & & \\
\hline
\end{tabular}


Table A-12. Mollugo verticillata \% Quadrat Cover vs. Environmental Variables, Single Linear Regressions Test Results

\begin{tabular}{|c|c|c|c|}
\hline \multirow[b]{2}{*}{ All Sites } & \multicolumn{3}{|c|}{ Relationships: + (Positive) } \\
\hline & A Horizon Depth & $\% 600 \mu \mathrm{m}$ to $212 \mu \mathrm{m}$ & $\% 212 \mu \mathrm{m}$ to $125 \mu \mathrm{m}$ \\
\hline $\mathrm{P}$ & & 0.022 & 0.049 \\
\hline Adjusted $\mathrm{R}^{2}$ & & 0.071 & 0.049 \\
\hline Relationship & & + & - \\
\hline $\begin{array}{l}\text { Upper } \\
\text { Riparian }\end{array}$ & A Horizon Depth & $\% 600 \mu \mathrm{m}$ to $212 \mu \mathrm{m}$ & $\% 212 \mu \mathrm{m}$ to $125 \mu \mathrm{m}$ \\
\hline$P$ & & & \\
\hline Adjusted $\mathrm{R}^{2}$ & & & \\
\hline Relationship & & & \\
\hline $\begin{array}{l}\text { Lower } \\
\text { Riparian }\end{array}$ & A Horizon Depth & $\% 600 \mu m$ to $212 \mu m$ & $\% 212 \mu \mathrm{m}$ to $125 \mu \mathrm{m}$ \\
\hline $\mathrm{P}$ & 0.027 & & \\
\hline Adjusted $\mathrm{R}^{2}$ & 0.132 & & \\
\hline Relationship & + & & \\
\hline
\end{tabular}

Table A-13. Oxalis corniculata \% Quadrat Cover vs. Environmental Variables, Single Linear Regressions Test Results

\begin{tabular}{|c|c|c|c|}
\hline \multirow[b]{2}{*}{ All Sites } & \multicolumn{2}{|c|}{ Relationships: + (Positive) - (Negative) } & \multirow{2}{*}{$\begin{array}{c}\text { Shaded (No Relationship, P > 0.05) } \\
\% \text { Gravel }\end{array}$} \\
\hline & Average 3 Meter Slope & & \\
\hline $\mathbf{P}$ & 0.021 & & 0.007 \\
\hline Adjusted $\mathrm{R}^{2}$ & 0.073 & & 0.105 \\
\hline Relationship & + & & + \\
\hline $\begin{array}{l}\text { Upper } \\
\text { Riparian } \\
\end{array}$ & Average 3 Meter Slope & & $\%$ Gravel \\
\hline $\mathrm{P}$ & & & \\
\hline Adjusted $\mathrm{R}^{2}$ & & & \\
\hline Relationship & & & \\
\hline $\begin{array}{l}\text { Lower } \\
\text { Riparian }\end{array}$ & Average 3 Meter Slope & & $\%$ Gravel \\
\hline $\mathrm{P}$ & 0.036 & & 0.035 \\
\hline Adjusted $R^{2}$ & 0.117 & & 0.119 \\
\hline Relationship & + & & + \\
\hline
\end{tabular}


Table A-14. Polygonum lapathifolium \% Quadrat Cover vs. Environmental Variables, Single Linear Regressions Test Results

\begin{tabular}{|c|c|c|c|}
\hline \multirow[b]{2}{*}{ All Sites } & \multicolumn{2}{|c|}{ Relationships: + (Positive) - (Negative) } & Shaded (No Relationship, $P>0.05$ \\
\hline & A Horizon Depth & & \%Clay. \\
\hline $\mathbf{P}$ & & & \\
\hline Adjusted $\mathrm{R}^{2}$ & & & \\
\hline Relationship & & & \\
\hline $\begin{array}{l}\text { Upper } \\
\text { Riparian }\end{array}$ & A Horizon Depth & & \%Clay \\
\hline $\mathrm{P}$ & 0.008 & & 0.049 \\
\hline Adjusted $\mathrm{R}^{2}$ & 0.201 & & 0.1 \\
\hline Relationship & + & & - \\
\hline $\begin{array}{l}\text { Lower } \\
\text { Riparian }\end{array}$ & A Horizon Depth & & \%Clay \\
\hline $\mathbf{P}$ & & & \\
\hline Adjusted $\mathrm{R}^{2}$ & & & \\
\hline
\end{tabular}

Table A-15. Rumex crispus \% Quadrat Cover vs. Environmental Variables, Single Linear Regressions Test Results

\begin{tabular}{|c|c|}
\hline \multirow[b]{2}{*}{ All Sites } & Relationships: + (Positive) - (Negative) Shaded (No Relationship, $P>0.05$ ) \\
\hline & $\%$ Gravel \\
\hline $\mathrm{P}$ & \\
\hline \multicolumn{2}{|l|}{ Adiusted $\mathrm{R}^{2}$} \\
\hline \multicolumn{2}{|l|}{ Relationship } \\
\hline $\begin{array}{l}\text { Upper } \\
\text { Riparian }\end{array}$ & $\%$ Gravel \\
\hline$P$ & 0.016 \\
\hline Adjusted $\mathrm{R}^{2}$ & 0.16 \\
\hline Relationship & + \\
\hline $\begin{array}{l}\text { Lower } \\
\text { Riparian }\end{array}$ & $\%$ Gravel \\
\hline \multicolumn{2}{|l|}{$P$} \\
\hline \multicolumn{2}{|l|}{ Adjusted $\mathrm{R}^{2}$} \\
\hline Relationship & \\
\hline
\end{tabular}


Table A-16. Salix exigua \% Quadrat Cover vs. Environmental Variables, Single Linear Regressions Test Results

\begin{tabular}{|c|c|c|c|}
\hline \multirow[b]{2}{*}{ All Sites } & \multicolumn{2}{|c|}{ Relationships: + (Positive) - (Negative) } & \multirow{2}{*}{$\begin{array}{l}\text { Shaded (No Relationship, } P>0.05 \text { ) } \\
\% 2.0 \mathrm{~mm} \text { to } 600 \mu \mathrm{m}\end{array}$} \\
\hline & A Horizon Depth & & \\
\hline $\mathrm{P}$ & 0.002 & & 0.008 \\
\hline Adjusted $\mathrm{R}^{2}$ & 0.142 & & 0.098 \\
\hline Relationship & - & & + \\
\hline $\begin{array}{l}\text { Upper } \\
\text { Riparian }\end{array}$ & A Horizon Depth & & $\% 2.0 \mathrm{~mm}$ to $600 \mu \mathrm{m}$ \\
\hline$P$ & 0.018 & & \\
\hline Adjusted $\mathrm{R}^{2}$ & 0.155 & & \\
\hline Relationship & - & & \\
\hline $\begin{array}{l}\text { Lower } \\
\text { Riparian }\end{array}$ & A Horizon Depth & & $\% 2.0 \mathrm{~mm}$ to $600 \mu \mathrm{m}$ \\
\hline$P$ & & & \\
\hline Adjusted $\mathrm{R}^{2}$ & & & \\
\hline Relationship & & & \\
\hline
\end{tabular}

Table A-17. Solidago occidentalis \% Quadrat Cover vs. Environmental Variables, Single Linear Regressions Test Results

\begin{tabular}{|c|c|c|c|c|c|c|c|}
\hline \multirow[b]{2}{*}{ All Sites } & \multicolumn{7}{|c|}{ Relationships: + (Positive) - (Negative) } \\
\hline & $\begin{array}{c}\text { Average } \\
3 \text { Meter } \\
\text { Slope }\end{array}$ & $\begin{array}{c}\% \\
\text { Gravel }\end{array}$ & \%Sand & $\%$ Silt & $\%$ Clay & $\begin{array}{l}\% 2.0 \mathrm{~mm} \\
\text { to } 600 \mu \mathrm{m}\end{array}$ & $\begin{array}{c}\% 600 \mu \mathrm{m} \text { to } \\
212 \mu \mathrm{m}\end{array}$ \\
\hline$P$ & 0.005 & & 0.002 & 0.003 & 0.002 & & 0.024 \\
\hline Adjusted $\mathrm{R}^{2}$ & 0.111 & & 0.135 & 0.125 & 0.14 & & 0.069 \\
\hline Relationship & + & & - & + & + & & - \\
\hline & & & & & & & \\
\hline $\begin{array}{l}\text { Upper } \\
\text { Riparian }\end{array}$ & $\begin{array}{c}\text { Average } \\
3 \text { Meter } \\
\text { Slope } \\
\end{array}$ & $\begin{array}{c}\% \\
\text { Gravel }\end{array}$ & \%Sand & $\%$ Silt & $\%$ Clay & $\begin{array}{l}\% 2.0 \mathrm{~mm} \\
\text { to } 600 \mu \mathrm{m}\end{array}$ & $\begin{array}{l}\% 600 \mu \mathrm{m} \text { to } \\
212 \mu \mathrm{m}\end{array}$ \\
\hline$P$ & 0.008 & $<0.001$ & & & & 0.001 & \\
\hline Adjusted $\mathrm{R}^{2}$ & 0.198 & 0.36 & & & & 0.329 & \\
\hline Relationship & + & + & & & & + & \\
\hline & & & & & & & \\
\hline $\begin{array}{l}\text { Lower } \\
\text { Riparian }\end{array}$ & $\begin{array}{c}\text { Average } \\
3 \text { Meter } \\
\text { Slope }\end{array}$ & $\begin{array}{c}\% \\
\text { Gravel }\end{array}$ & \%Sand & $\%$ Silt & \%Clay & $\begin{array}{l}\% 2.0 \mathrm{~mm} \\
\text { to } 600 \mu \mathrm{m}\end{array}$ & $\begin{array}{c}\% 600 \mu \mathrm{m} \text { to } \\
212 \mu \mathrm{m}\end{array}$ \\
\hline$P$ & & & 0.002 & 0.003 & 0.005 & & 0.044 \\
\hline Adjusted $\mathrm{R}^{2}$ & & & 0.26 & 0.246 & 0.224 & & 0.106 \\
\hline Relationship & & & - & + & + & & - \\
\hline
\end{tabular}


Table A-18. OBL \%Quadrat Cover vs. Environmental Variables, Single Linear Regressions Results

\begin{tabular}{|c|c|c|c|c|}
\hline \multirow[b]{2}{*}{ All Sites } & \multicolumn{2}{|c|}{ Relationships: + (Positive) - (Negative } & \multicolumn{2}{|c|}{ Shaded (No Relationship, $P>0.05$ ) } \\
\hline & Depth to C & Avg $3 \mathrm{~m}$ slope & $\%$ Clay & $\% 125 \mu m$ to $63 \mu m$ \\
\hline$P$ & $<0.001$ & & & 0.040 \\
\hline Adjusted $\mathrm{R}^{2}$ & 0.204 & & & 0.054 \\
\hline Relationship & - & & & - \\
\hline $\begin{array}{l}\text { Upper } \\
\text { Riparian }\end{array}$ & Depth to C & Avg 3m slope & \%Clay & $\% 125 \mu m$ to $63 \mu m$ \\
\hline$P$ & & 0.034 & & \\
\hline Adjusted $\mathrm{R}^{2}$ & & 0.120 & & \\
\hline Relationship & & - & & \\
\hline $\begin{array}{l}\text { Lower } \\
\text { Riparian }\end{array}$ & Depth to C & Avg 3m slope & $\%$ Clay & $\% 125 \mu \mathrm{m}$ to $63 \mu \mathrm{m}$ \\
\hline$P$ & & & 0.014 & \\
\hline Adjusted $\mathrm{R}^{2}$ & & & 0.167 & \\
\hline Relationship & & & + & \\
\hline
\end{tabular}

Table A-19. FACW \%Quadrat Cover vs. Environmental Variables, Single Linear Regressions Results

\begin{tabular}{|c|c|c|c|}
\hline \multirow[b]{2}{*}{ All Sites } & Relationships: + (Positive) & + (Positive) - (Negative) & Shaded (No Relationship, $P>0.05$ ) \\
\hline & Depth to C & $\%$ Gravel & $\% 212 \mu \mathrm{m}$ to $125 \mu \mathrm{m}$ \\
\hline$P$ & $<0.001$ & & 0.034 \\
\hline Adjusted $\mathrm{R}^{2}$ & 0.234 & & 0.059 \\
\hline Relationship & + & & + \\
\hline $\begin{array}{l}\text { Upper } \\
\text { Riparian }\end{array}$ & Depth to C & $\%$ Gravel & $\% 212 \mu \mathrm{m}$ to $125 \mu \mathrm{m}$ \\
\hline $\mathbf{P}$ & 0.038 & & \\
\hline Adjusted $\mathrm{R}^{2}$ & 0.114 & & \\
\hline Relationship & + & & \\
\hline $\begin{array}{l}\text { Lower } \\
\text { Riparian }\end{array}$ & Depth to C & $\%$ Gravel & $\% 212 \mu \mathrm{m}$ to $125 \mu \mathrm{m}$ \\
\hline $\mathbf{P}$ & & 0.037 & 0.039 \\
\hline Adjusted $\mathrm{R}^{2}$ & & 0.116 & 0.113 \\
\hline Relationship & & - & + \\
\hline
\end{tabular}


Table A-20. FACU \%Quadrat Cover vs. Environmental Variables, Single Linear Regressions Results

\begin{tabular}{|c|c|c|c|}
\hline \multirow[b]{2}{*}{ All Sites } & \multicolumn{2}{|c|}{ Relationships: + (Positive) - (Negative) } & \multirow{2}{*}{$\frac{\text { Shaded (No Relationship, P > 0.05) }}{\% \text { Gravel }}$} \\
\hline & Avg 3m slope & & \\
\hline$P$ & 0.007 & & 0.040 \\
\hline Adjusted $\mathrm{R}^{2}$ & 0.103 & & 0.055 \\
\hline Relationship & + & & + \\
\hline $\begin{array}{l}\text { Upper } \\
\text { Riparian }\end{array}$ & Avg 3m slope & & $\%$ Gravel \\
\hline$P$ & & & \\
\hline Adjusted $\mathrm{R}^{2}$ & & & \\
\hline Relationship & & & \\
\hline $\begin{array}{l}\text { Lower } \\
\text { Riparian }\end{array}$ & Avg $3 \mathrm{~m}$ slope & & $\%$ Gravel \\
\hline$P$ & 0.006 & & \\
\hline Adjusted $\mathrm{R}^{2}$ & 0.211 & & \\
\hline
\end{tabular}

Table A-21. UPL \%Quadrat Cover vs. Environmental Variables, Single Linear Regressions Results

\begin{tabular}{|c|c|c|}
\hline \multirow[b]{2}{*}{ All Sites } & \multicolumn{2}{|c|}{ Relationships: + (Positive) - (Negative) Shaded (No Relationship, $P>0.05$} \\
\hline & $\% 600 \mu \mathrm{m}$ to $212 \mu \mathrm{m}$ & $\% 125 \mu \mathrm{m}$ to $63 \mu \mathrm{m}$ \\
\hline $\mathbf{P}$ & 0.005 & 0.010 \\
\hline Adjusted $\mathrm{R}^{2}$ & 0.115 & 0.093 \\
\hline Relationship & + & - \\
\hline $\begin{array}{l}\text { Upper } \\
\text { Riparian }\end{array}$ & $\% 600 \mu \mathrm{m}$ to $212 \mu \mathrm{m}$ & $\% 125 \mu m$ to $63 \mu m$ \\
\hline$P$ & & \\
\hline Adjusted $\mathrm{R}^{2}$ & & \\
\hline Relationship & & \\
\hline $\begin{array}{l}\text { Lower } \\
\text { Riparian }\end{array}$ & $\% 600 \mu m$ to $212 \mu m$ & $\% 125 \mu \mathrm{m}$ to $63 \mu \mathrm{m}$ \\
\hline $\mathrm{P}$ & & \\
\hline Adjusted $\mathrm{R}^{2}$ & & \\
\hline Relationship & & \\
\hline
\end{tabular}




\section{APPENDIX B: RESIDUAL VS. THEORETICAL QUANTILE PLOTS FOR RELATIONSHIPS IDENTIFIED IN ONLY ONE ZONE}

Figure B-1. \%Gravel vs. \%Upper Quadrat Cover by Solidago occidentalis

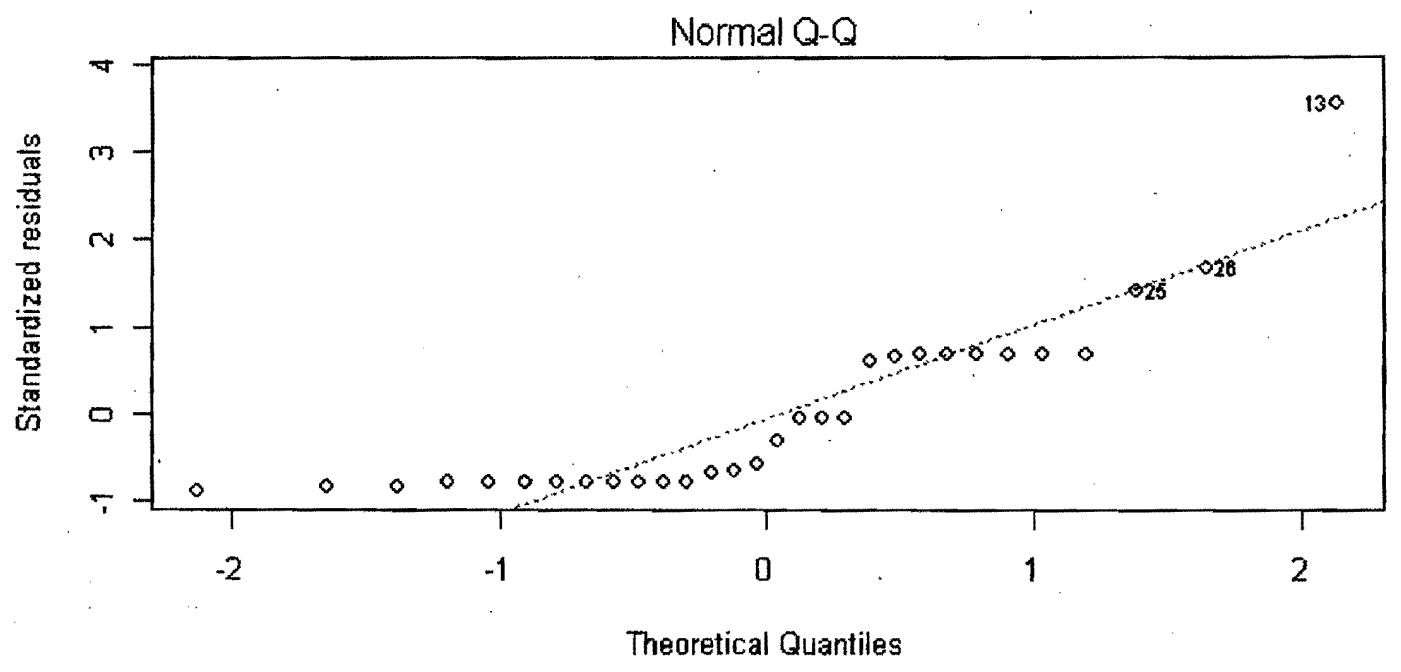

Figure B-2. \% $2.0 \mathrm{~mm}$ to $600 \mu \mathrm{m}$ vs. \%Upper Quadrat Cover by Solidago occidentalis

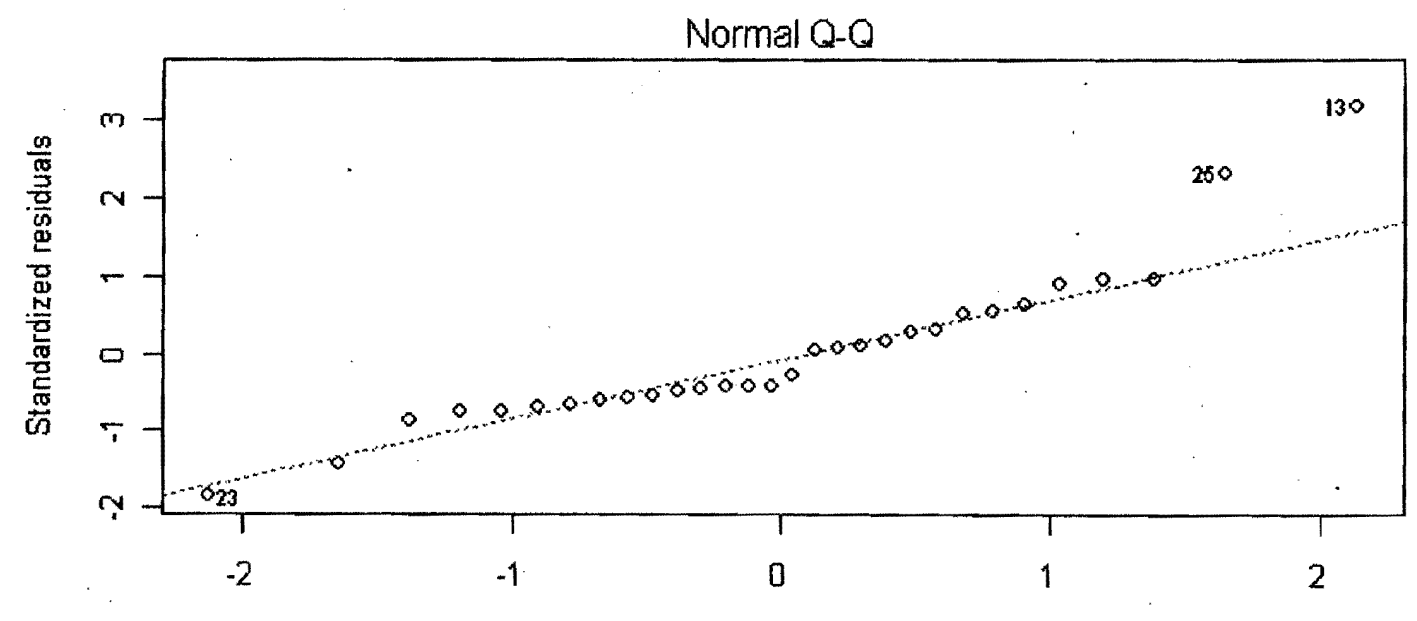

Theoretical Quantiles 
Figure B-3. \% Clay vs. \% Upper Quadrat Cover by Polygonum lapathifolium

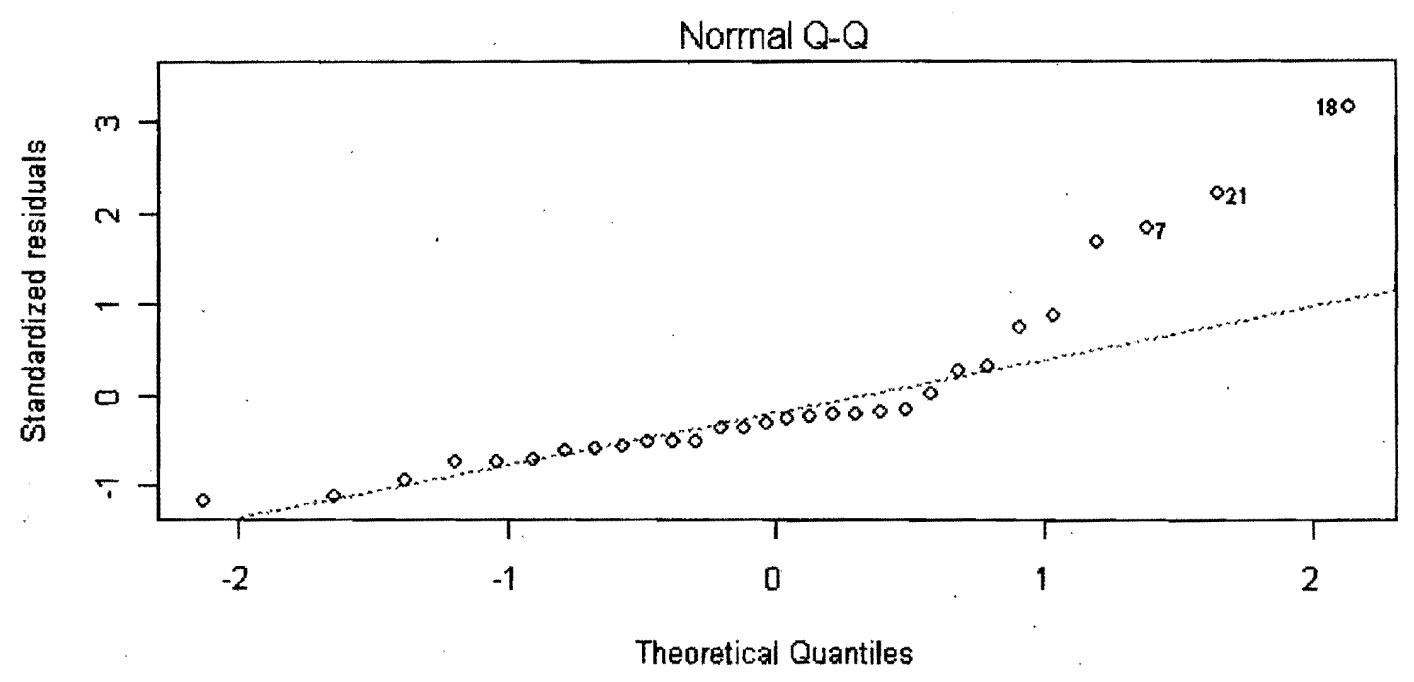

Figure B-4. Horizon Depth vs. \%Upper Quadrat Cover by Polygonum lapathifolium

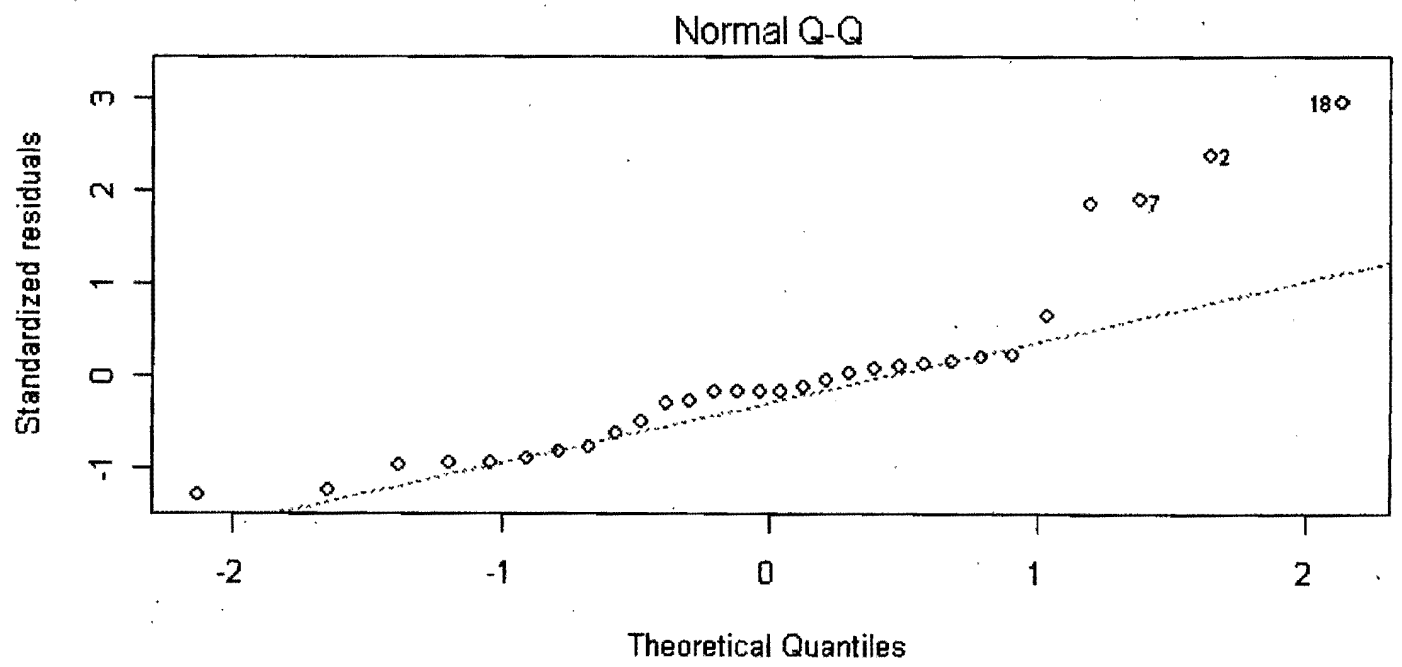


Figure B-5. $\% 600 \mu \mathrm{m}$ to $212 \mu \mathrm{m}$ vs. \%Lower Quadrat Cover by Equisetum arvense

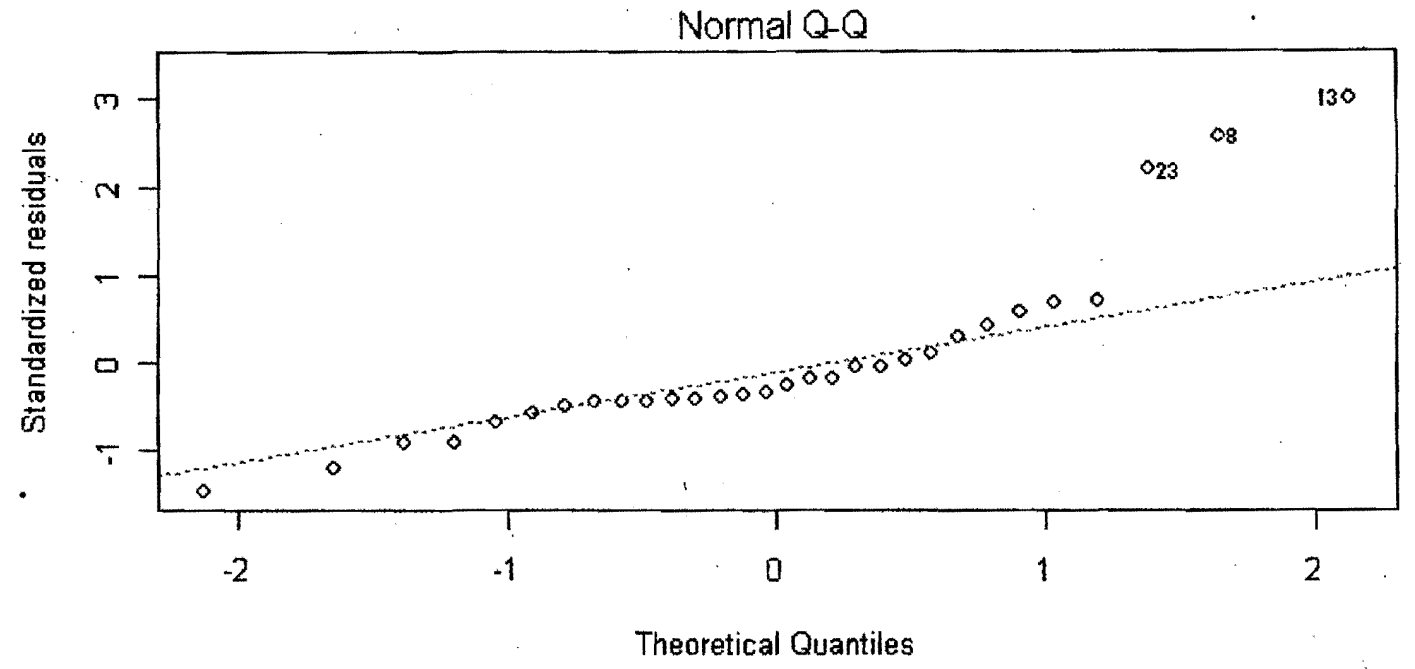

Figure B-6. \%125 $\mu \mathrm{m}$ to $63 \mu \mathrm{m}$ vs. \%Lower Quadrat Cover by Equisetum arvense

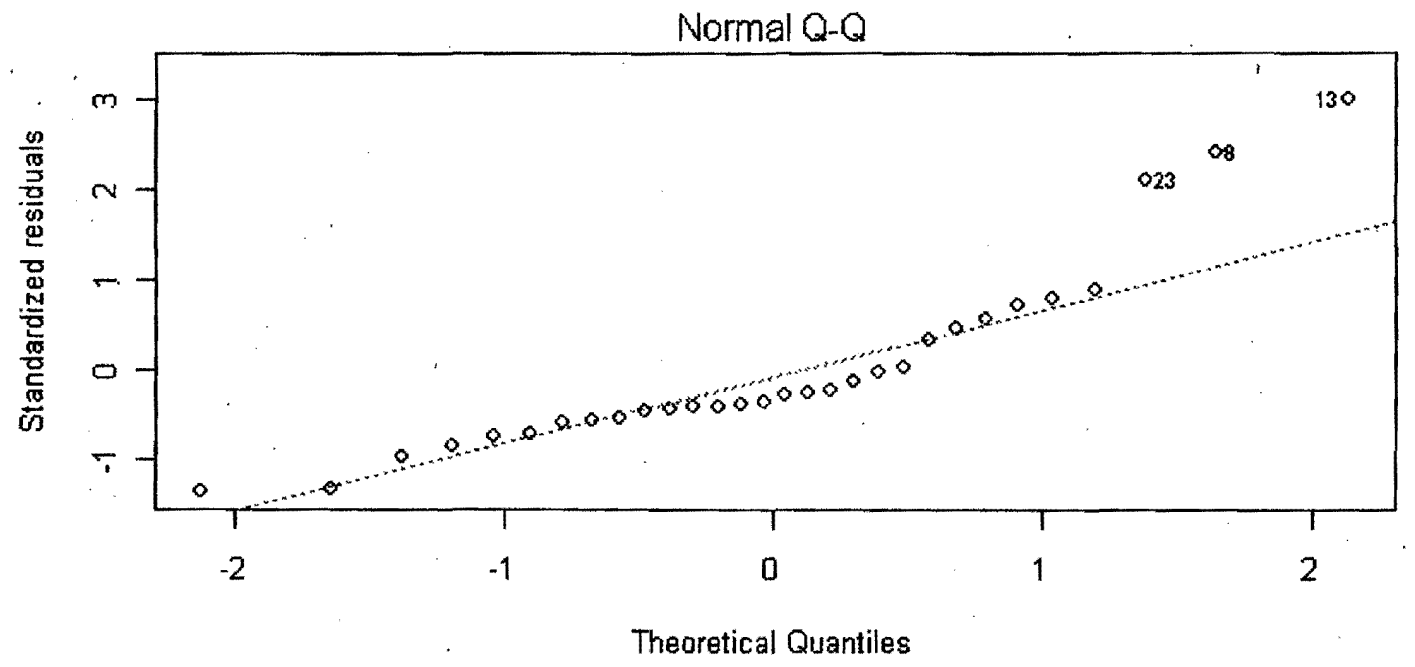




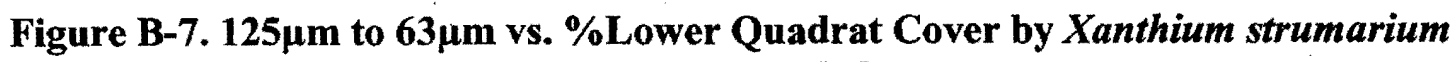

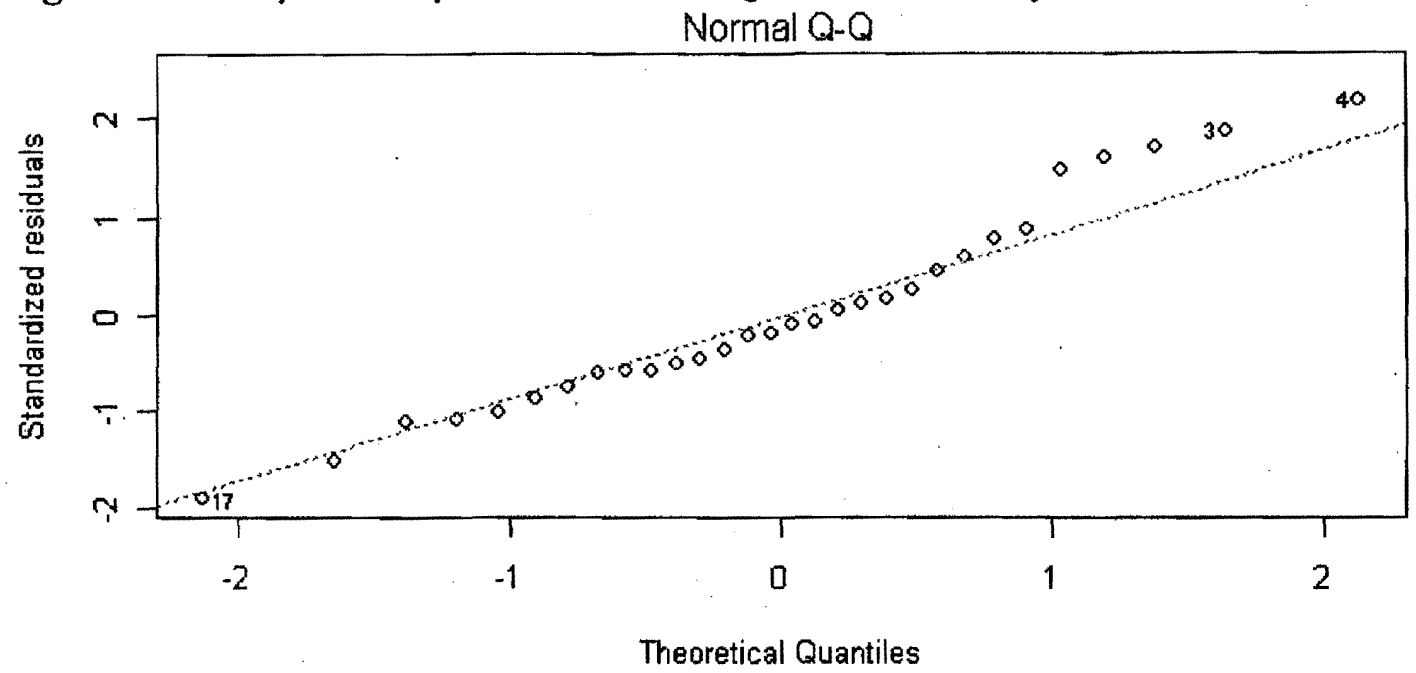

Figure B-8. A Horizon Depth vs. \%Lower Quadrat Cover by Euphorbia supina

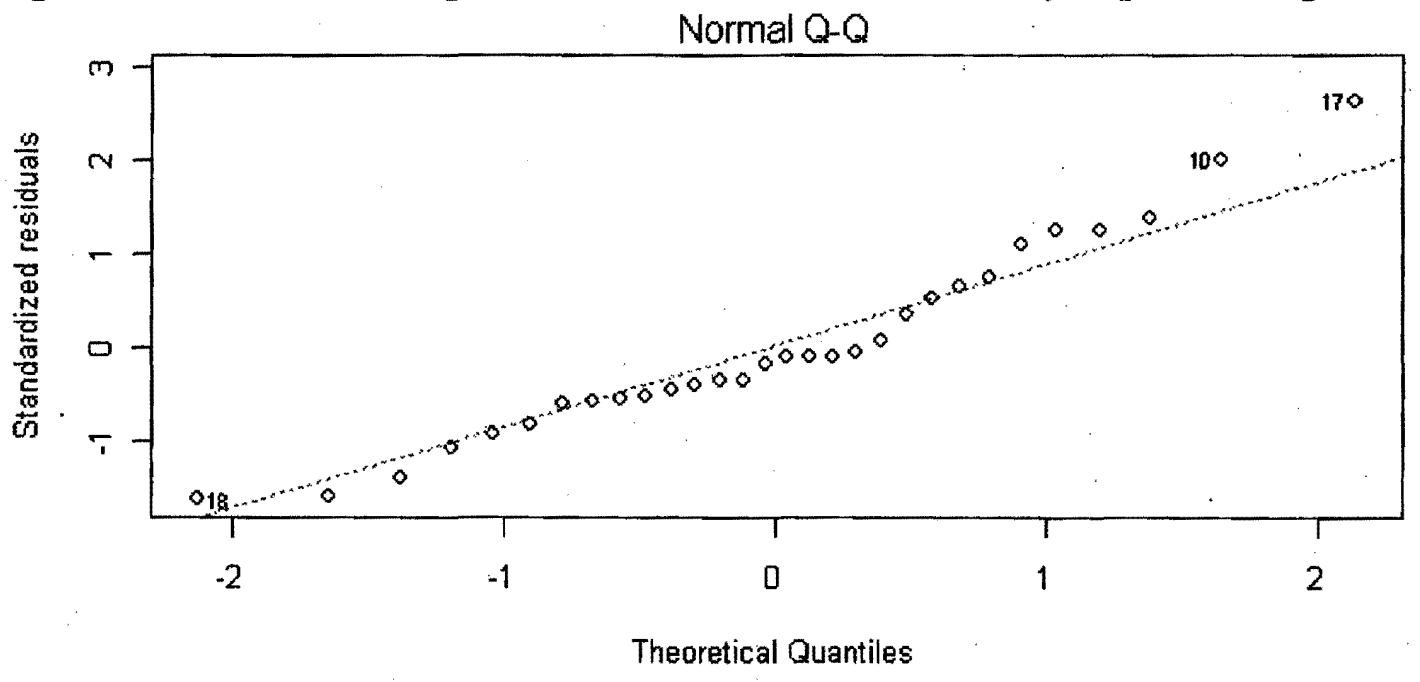


Figure B-9. A Horizon Depth vs. \%Lower Quadrat Cover by Leersia oryzoides

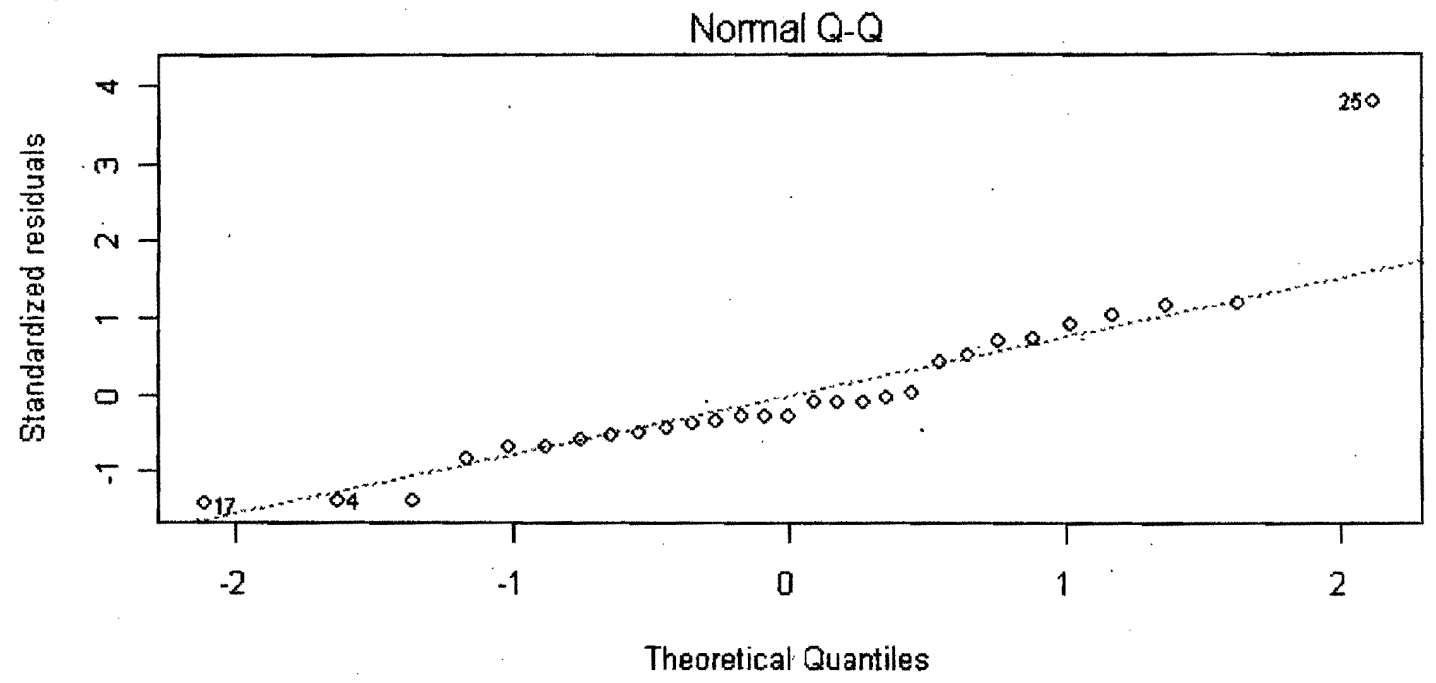

Figure B-10. pH vs. \%Lower Quadrat Cover by Xanthium strumarium

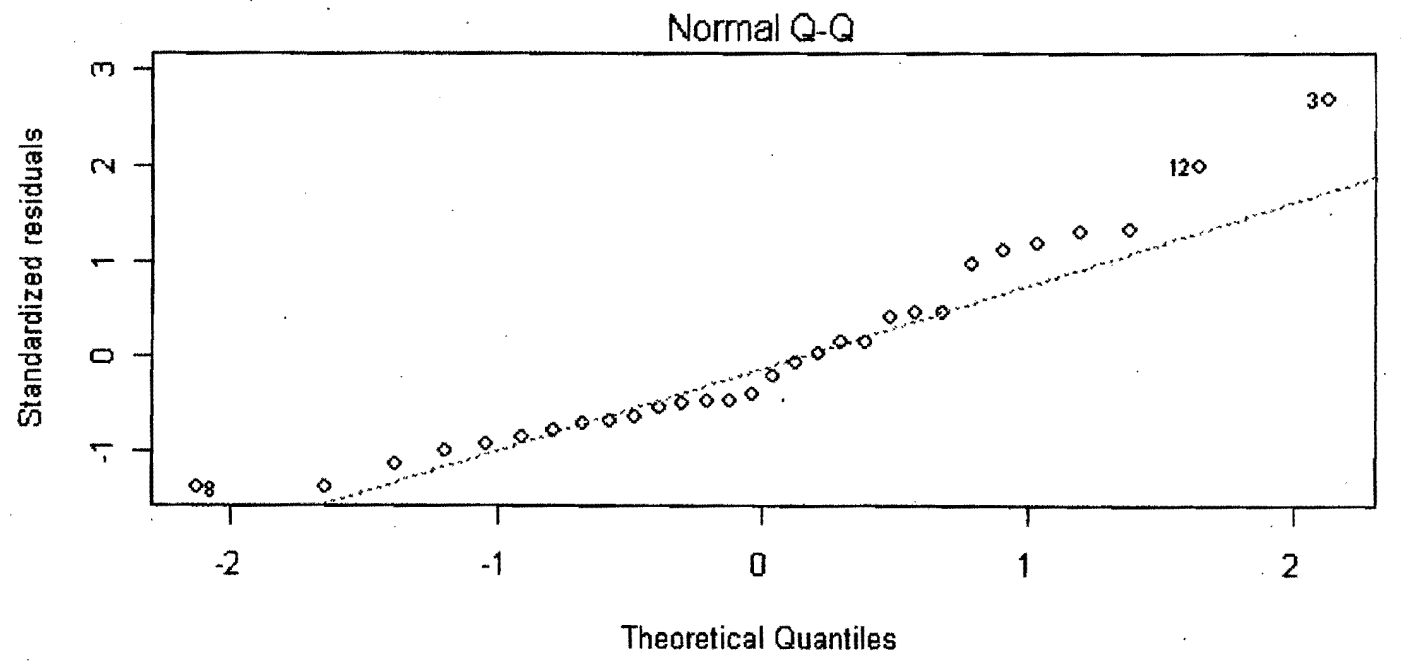


Figure B-11. Average Slope vs. \%Upper Quadrat Cover by OBL Species

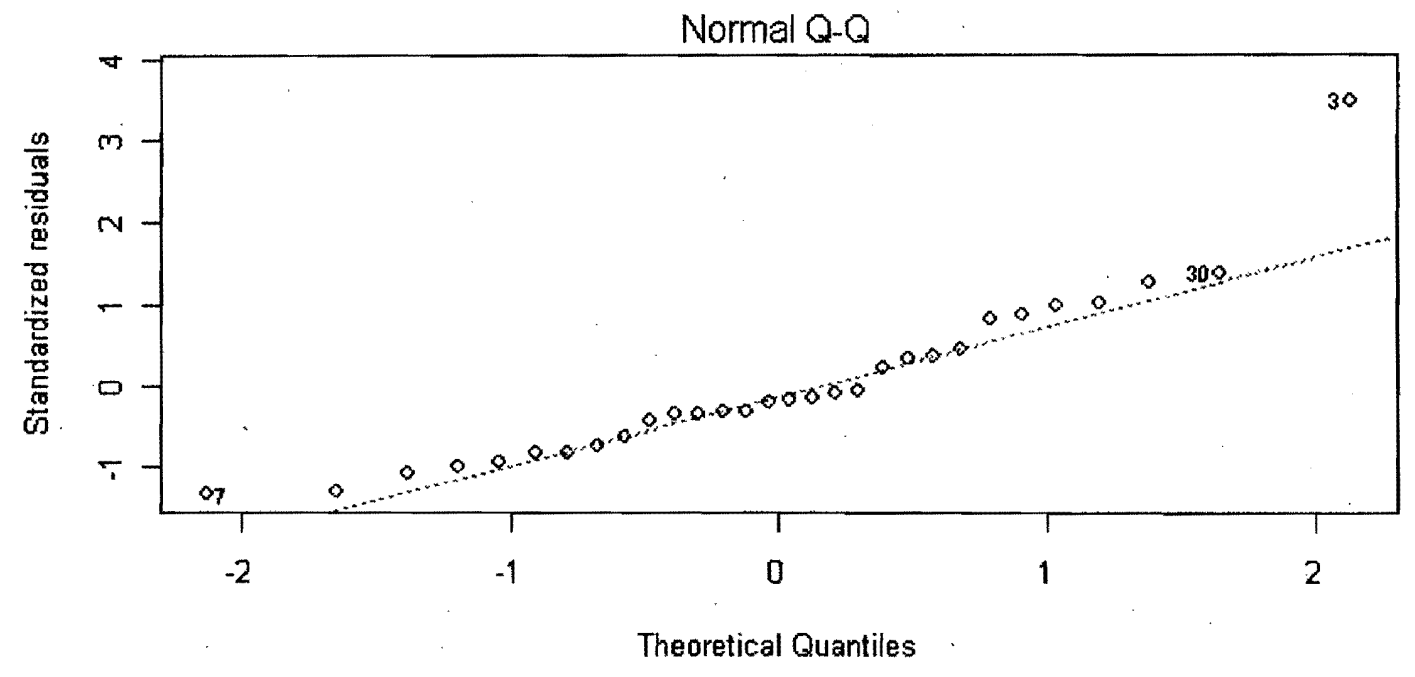

Figure B-12. \% Clay vs. \%Lower Quadrat Cover by OBL Species

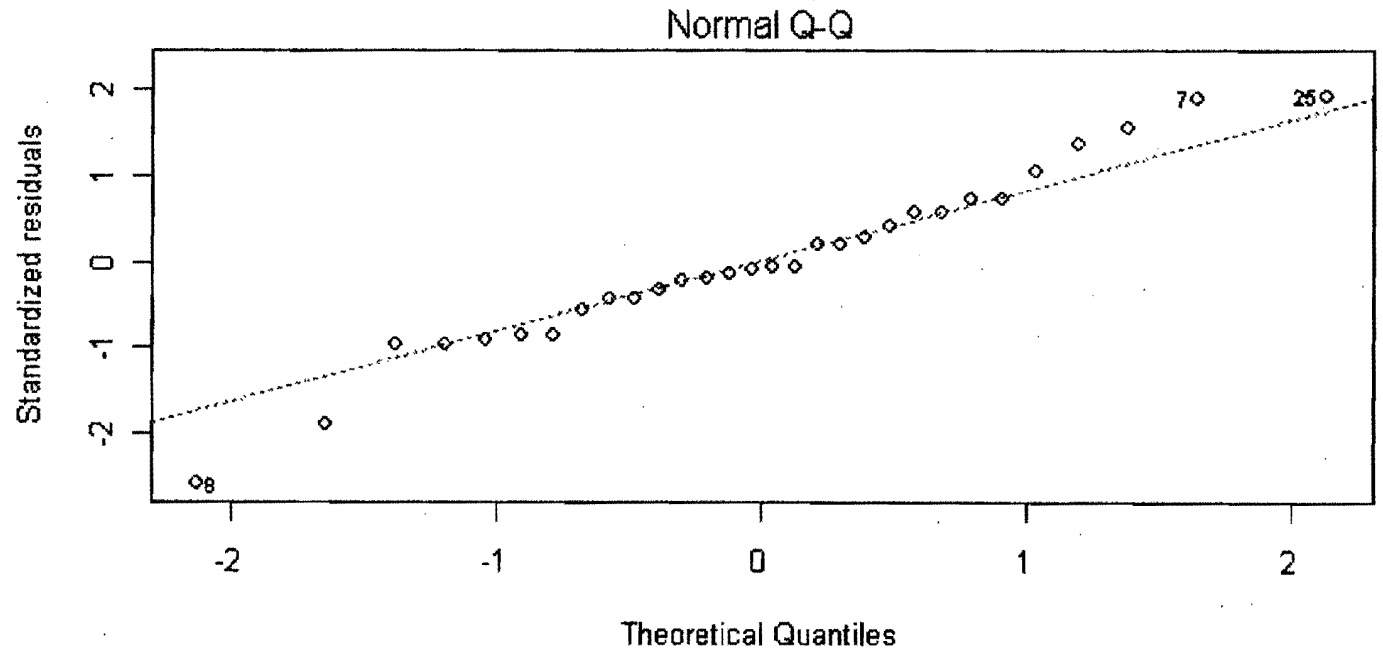

